Universidade Estadual Paulista "Júlio de Mesquita Filho" Faculdade de Medicina de Botucatu

Maíra Rodrigues Baldin Dal Pogetto

Prevalência das Doenças Sexualmente Transmissíveis em Mulheres Profissionais do Sexo do Município de Botucatu, São Paulo 


\section{Prevalência das Doenças Sexualmente Transmissíveis em Mulheres Profissionais do Sexo do Município de Botucatu/SP}

Mestranda: Maíra Rodrigues Baldin Dal Pogetto Orientadora: Profa Adjunta Cristina Maria Garcia de Lima Parada Co-orientadora: Prof ${ }^{\mathrm{a}} \mathrm{Dr}^{\mathrm{a}}$ Márcia Guimarães da Silva

Dissertação apresentada ao Programa de PósGraduação em Enfermagem - Mestrado Profissional - da Faculdade de Medicina de Botucatu da Universidade Estadual Paulista "Júlio de Mesquita Filho", como parte dos requisitos para obtenção do título de Mestre em Enfermagem

\section{Botucatu}

2010 
FICHA CATALOGRÁFICA ELABORADA PELA SEÇÃO TÉCNICA DE AQUISIÇÃO E TRATAMENTO DA INFORMAÇÃO

DIVISÃO TÉCNICA DE BIBLIOTECA E DOCUMENTAÇÃO - CAMPUS DE BOTUCATU - UNESP BIBLIOTECÁRIA RESPONSÁVEL: Selma Maria de Jesus

Dal Pogetto, Maíra Rodrigues Baldin.

Prevalência das doenças sexualmente transmissíveis em mulheres

profissionais do sexo do Município de Botucatu/SP / Maíra Rodrigues Baldin.

- Botucatu : [s.n.], 2010.

Dissertação (mestrado) - Enfermagem - Faculdade de Medicina de Botucatu, Universidade Estadual Paulista, 2010.

Orientadora: Cristina Maria Garcia de Lima Parada

Assunto CAPES: 40405001

1. Doenças sexualmente transmissíveis $\quad 2$. Enfermagem

CDD 616.951

Palavras-chave: Enfermagem; Infecção; Prevalência; Saúde da mulher 


\title{
Prevalência das Doenças Sexualmente Transmissíveis em Mulheres Profissionais do Sexo do Município de Botucatu/SP
}

\author{
Mestranda: Maíra Rodrigues Baldin Dal Pogetto Dal Pogetto \\ Orientadora: Profa Dra Cristina Maria Garcia de Lima Parada

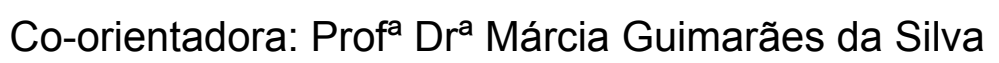

\begin{abstract}
Dissertação apresentada ao Programa de PósGraduação em Enfermagem - Mestrado Profissional - da Faculdade de Medicina de Botucatu da Universidade Estadual Paulista "Júlio de Mesquita Filho", como parte dos requisitos para obtenção do título de Mestre em Enfermagem
\end{abstract}

\section{Banca Examinadora:}

\section{Prof $^{a}$ Adj Cristina Maria Garcia de Lima Parada}

Faculdade de Medicina de Botucatu da Universidade Estadual Paulista "Júlio de Mesquita Filho"

\section{Prof. Dr. Mauro Romero Leal Passos}

Local Universidade Federal Fluminense

Profa. Dra. Maria Antonieta de Barros Leite Carvalhaes

Faculdade de Medicina de Botucatu da Universidade Estadual Paulista "Júlio de Mesquita Filho" 
Trabalho realizado nos Departamentos de Enfermagem e Patologia da Faculdade de Medicina de Botucatu e no Instituto de Biociências da Universidade Estadual Paulista "Júlio de Mesquita Filho", com participação de técnicos do Programa de DST/aids da Secretaria Municipal de Saúde de Botucatu e com suporte financeiro da Fundação de Amparo à Pesquisa do Estado de São Paulo (FAPESP, Processo 2008/58177-5) 


\section{Dedico esta dissertação}

\section{Primeiramente aos}

mens exemplos de vida, Alir e Jurema, que estiveram ao mew lado me encorajando nas horas dificeis e me aplaudindo nos momentos de glóría. Obrigada por serem meus pais e fonte de inspiração, apoio e ensino diário.

Ao meu marido Henrique, companheiro querido, por acrescentar razão e beleza aos meus dias, encorajando-me a prosseguir na execução desta dissertação, por partithar comigo e sacrificar muitos momentos que poderíamos ter desfrutado juntos, mas sempre incentivou, sempre apoioue, $\sigma$ methor de tudo, sempre me cobrow para que eu continuasse e concluisse mais esta etapa, sendo minha mais importante fonte de apoio intelectual e afetivo, sem os quais certamente este trabalho não chegaria ao fim. Obrigada por me ensinar que um relacionamento só se constrói em cima de bases sólidas e por fazer parte da minha vida, por ser um homem integro, um profissional exemplar e um amigo sincero.

"Sua existência é minha festa interior"

À minha irmã Samira, por todo apoí, carinho e amor, especialmente por me suportar pacientemente. Obrigada por estar sempre ao meu lado e depositar em mim a confiança para todas as horas.

"Agradeço a Deus por ter me dado a oportunidade de estar no mundo e me amparar nos momentos dificeis, me dar força interior para superar as dificuldades, mostrar os caminhos nas horas incertas e me suprir em todas as minhas necessidades" 
Agradecimentos Especiais

Agradecimentos Especiais 
À minha orientadora Prof. ${ }^{a}$ Dr. ${ }^{a}$ Cristina Maria Garcia de Lima Parada

Por ser uma interlocutora disposta a oferecer estimulose,

principalmente, a percorrer novos caminhos, ouvir com interesse e ânimo todas as questões, dividas e problemas que surgiam durante este processo. Por ser paciente e generosa e pela coragem de ousar trabalhar com novas ideias.

Por sua amizade, principalmente, pela compreensão silenciosa nos momentos dificeis pelos quais passei, permitindo que meu tempo interno fluisse, respeitosamente.

A sua disponibilidade irrestrita, empenho, dedicação, sabedoria, compreensão e, acima de tudo, exigência, creio que deram norte a este trabalho, facilitando $\sigma$ alcance de sens objetivos.

À minha co-orientadora Prof. ${ }^{a}$ Dr. ${ }^{a}$ Márcia Guimarães da Sítva

Também minha professora desde a graduação, por ter despertado em mim o interesse deste trabalho e me acolher tão bem. Gostaria de ratificar a sua competência e participação que foi fundamental para a realização deste trabalho.

\section{Pela alegria de trabalharmos juntas por serem exemplos de profissionais.}


Agradecimentos

Agradecimentos 
Agradeço a todas as pessoas que me ajudaram, apoiarame incentivaram na concretização desse trabalho.

Às agentes do Programa Municipal DST/Aids (Vivi, Micheti, Viviane e Liriam) agradeço profundamente por tornarem possivel a realização deste trabalho sendo prestativas, dedicadas e competentes.

À companheira e amiga Larissa Doddi, nos divertimos muito juntas em lugares inusitados!!!

À Secretaria Municipal de Saide de Botucatu pelo apoio para $\sigma$ desenvolvimento deste trabalho, em especial a enfermeira Rosana kron que atendew a todas as minhas solicitaçöes prontamente.

Às auxiliares de enfermagem Fabiana e Elisama, minhas companheiras de trabalho: gestos de carinho, dedicação, atenção e delicadeza fazem-nos perceber quanto algumas pessoas são especiais na forma de ser e como são bem-vindas as suas ações.

À equipe do Jardim Iolanda pela compreensão relativa à minha ausência temporáría e por me proporcionar um crescimento não só profissional, mas também pessoal, em especial aos mens companheiros e amigos, Oscar e Lucele que sempre estiveram ao meu lado dando força e apoio, muito obrigada!

À minha amiga Telma, pela sinceridade de nossa amizade acima de qualquer outra coisa, companheirismo, dedicação e sábios conselhos, sua presença foi muito importante. 
À minha amiga-irmã Edwa, por sua força, entusiasmoe otimismo contagiantes, por sempre torcer por mim! À minha amiga Fernanda, pela ajuda nas coletas dos dados e sempre fazer sugestöes oportunas.

Aos professores Mauro, Elvira e Maria Antonieta que proporcionaram discussões e sugestöes em busca da melhoria deste trabalho.

À Aline pela disposição, paciêncía e sorriso acolhedor è Heloisa pela digitação do banco de dados (Pós-Graduação do Departamento de Enfermagem).

Às meninas do laboratório do Departamento de Patologia pelo preparo de meio e análises dos materiais.

Ao professor José Eduardo Corrente pela análise estatistica.

Às bibliotecárias Meire e Selma pela revisão das referências bibliográficas e elaboração da ficha catalográfica.

Ao Laboratório da Faculdade de Medicina - UNESP, pelas análises sorológicas, em especial a Dra Nádia dos Reis Carvalho.

À FAPESP pelo financiamento do projeto.

"Eugosto do que eupenso, en gosto do que eu faço, às vezes não faço bem feito e me embaraço, tropeço feio mais depois acerto $\sigma$ passo". 
Epigrafe 


\section{A Idade de Ser Feliz}

Existe somente uma idade para a gente ser feliz, somente uma época na vida de cada pessoa em que é possivel sonhar e fazer planos e ter energia bastante para realizá-las a despeito de todas as dificuldades e obstáculos.

Uma só idade para a gente se encantar com a vída e víver apaixonadamente e desfrutar tudo com toda intensidade sem medo, nem culpa de sentir prazer.

Fase dourada em que a gente pode criar e recriar a vida, a nossa própría imagem e semelhança evestir-se com todas as cores e experimentar todos os sabores e entregar-se a todos os amores sem preconceito nem pudor.

Tempo de entusiasmo e coragem em que todo o desafio é mais um convite à luta que a gente enfrenta com toda disposição de tentar algo NOVO, de NOVO e de NOVO, e quantas vezes for preciso.

Essa idade tão fugaz na vida da gente chama-se PRESENTE

e tem a duração do instante que passa.

(Desconhecido) 
LISTA DE TABELAS 
Tabela 1. Variáveis sociodemográficas e antecedentes obstétricos e de imunização relacionados às PS $(n=102)$ estudadas. Botucatu, 2009

Tabela 2. Antecedentes ginecológicos das PS $(n=102)$ estudadas. Botucatu, 2009

Tabela 3. Queixa ginecológica e características, de acordo com as PS estudadas. Botucatu, 2009.

Tabela 4. Fatores comportamentais das PS $(n=102)$ estudadas. Botucatu, 2009

Tabela 5. Achados ginecológicos encontrados durante exame especular das PS estudadas. Botucatu, 2009

Tabela 6. Ocorrência de DST, tipagem do HPV, imunidade para Hepatite B e resultado da CO das PS $(n=102)$ estudadas. Botucatu, 2009.

Tabela 7. Associação entre DST e idade e variáveis ginecológicas das PS estudadas ( $n=102)$. Botucatu, 2009.

Tabela 8. Associação entre DST e achados clínicos das PS estudadas ( $n=102)$. Botucatu, 2009.

Tabela 9. Associação entre DST e variáveis comportamentais das PS estudadas ( $n=102)$. Botucatu, 2009.

Tabela 10. Associação entre HPV e idade e variáveis ginecológicas das PS estudadas ( $n=102)$. Botucatu, 2009.

Tabela 11. Associação entre HPV e achados clínicos das PS estudadas ( $n=102)$. Botucatu, 2009.

Tabela 12. Associação entre HPV e variáveis comportamentais das PS estudadas $(n=102)$. Botucatu, 2009. 
RESUMO

SUMMARY 22

1. INTRODUÇÃO _ 23

1.1. Profissionais do Sexo: construção social, preconceito e legislação _ 29

1.2. Prevalência das Doenças Sexualmente Transmissíveis no Brasil e no mundo

2. OBJETIVOS 46

2.1. Objetivo geral 47

2.2. Objetivos específicos__ 47

3. MÉTODO 48

3.1. Desenho do Estudo e Local de Realização ___ 49

3.2. População de Estudo __ 51

3.3. Coleta de conteúdo vaginal, secreção cervical e sangue ___ 51

3.4. Variáveis Estudadas __ 53

3.5. Procedimentos Técnicos Relacionados aos Exames Realizados $\quad 55$

3.5.1. Pesquisa de CT e HPV: extração do DNA com solução CTAB_— 55

3.5.2. Pesquisa de Neisseria gonorrhoeae __ 58

3.5.3. Pesquisa de Trichomonas vaginalis — 58

3.5.4. Citologia oncótica tríplice___ 59

3.5.5. Sorologias _ 59

3.5.5.1. Pesquisa de Sífilis _ 60

3.5.5.2. Pesquisa do vírus da Hepatite B 60

3.5.5.3. Pesquisa do HIV _ 60

3.6. Análise dos Dados __ 61

3.7. Procedimentos Éticos _ 61

4. RESULTADOS 62

5. DISCUSSÃO__ 78

6. CONCLUSÕES___ 95

7. REFERÊNCIAS _ 98

8. ANEXOS 117

8.1. Anexo 1: Instrumento para coleta de dados ___ 118

8.2. Anexo 2: Aprovação do Comitê de Ética em Pesquisa___ 120

8.3. Anexo 3: Termo de Consentimento Livre Esclarecido __ 121 
Resumo-DST em profissionais do sexo 


\section{RESUMO}

Mudanças sóciossexuais têm alterado o perfil das doenças sexualmente transmissíveis, ampliando a necessidade de seu rastreamento, especialmente onde existe concentração de pessoas ou grupos com comportamentos de risco, para que a detecção dessas doenças e seu tratamento imediato se traduzam na redução dos problemas causados. As profissionais do sexo apresentam a característica singular de manterem atividade sexual intensa, com vários coitos por dia, acrescida do uso de substâncias químicas locais e microtraumatismos vaginais, 0 que as deixa vulneráveis às doenças sexualmente transmissíveis. Objetivo geral: identificar a prevalência de doenças sexualmente transmissíveis entre profissionais do sexo do município de Botucatu/SP e verificar a associação com variáveis sociodemográficas e comportamentais. Método: trata-se de estudo de prevalência populacional. Foram incluídas no estudo 102 profissionais do sexo, os dados foram colhidos durante o ano de 2008 e a propedêutica de atendimento das mulheres incluía a coleta de sangue, de conteúdo vaginal e de secreção cervical para detecção das seguintes doenças sexualmente transmissíveis: hepatite $B$; sífilis; aids; tricomoníase; infecção clamidiana, gonorreia e a presença de papilomavírus humano. Resultados: a média de idade das participantes do estudo foi 26,1 anos, sendo que a maioria tinha nove ou mais anos de aprovação escolar $(53,0 \%)$, era solteira $(71,6 \%)$, usava contraceptivo $(92,2 \%)$, negava história de doença sexualmente transmissível prévia $(77,5 \%)$ e referiu a primeira relação sexual antes dos 15 anos (59,8\%). A prática de sexo oral foi citada por $90,2 \%$ das mulheres e $37,3 \%$ delas referiram praticar sexo anal. Em relação às medidas de prevenção, $99 \%$ das profissionais do sexo relataram fazer uso do preservativo no trabalho e somente $26,3 \%$ das mulheres que tinham parceiro fixo relataram seu uso neste caso. O consumo de tabaco, álcool e drogas ilícitas foi elevado: $68,6 \%, 84,3 \%$ e $42,2 \%$, respectivamente. A citologia oncótica foi normal para $95 \%$ das mulheres, já que apenas cinco delas apresentaram algum tipo de alteração celular no exame. Estavam imunizadas contra a Hepatite B $66,7 \%$ das mulheres. A prevalência de doenças sexualmente transmissíveis foi de $71,6 \%$. Considerados isoladamente e em associação, apresentaram as maiores prevalências o HPV $(67,7 \%)$ e a infecção clamidiana (20,5\%). A tipagem do HPV evidenciou a presença de genótipos oncogênicos. A prevalência de sífilis foi de 4,0\%. Nenhum caso de hepatite B ou gonorreia foi identificado. Conclusões: A população estudada era majoritariamente de mulheres adultas jovens, com escolaridade semelhante à média geral da população brasileira. Hábitos como tabagismo, uso de álcool e de drogas ilícitas foram frequentes. Não houve qualquer associação entre DST, sinais e sintomas ginecológicos referidos e variáveis sociodemográficas e comportamentais relativas às profissionais do sexo estudadas. Em síntese, a prevalência de DST no grupo estudado foi elevada, pois aproximadamente dois terços das mulheres apresentavam alguma doença deste tipo.

Descritores: Infecção; Saúde da Mulher; Prevalência; Enfermagem 
Summary - DST em profissionais do sexo 


\section{SUMMARY}

Socio-sexual changes have altered the profile of sexually transmitted diseases (STD) and increased the need for their tracking, particularly in places where there is a concentration of individuals with a risk behavior, so that the detection of such diseases and their immediate treatment can be translated into the reduction of resulting problems. Sex professionals (SP) have the singular characteristic of maintaining intense sexual activity, with various intercourses per day, which is added to the use of topical chemical substances and vaginal microtrauma and makes them vulnerable to STD. Aim: To identify the prevalence of STD among SP the city of Botucatu/SP and evaluate the association with sociodemographic and behavioral variables. Method: This is a population prevalence study. One hundred and two SP were included; data were collected in 2008, and the propedeutics of the women's care included the collection of blood, vaginal content and cervical secretion for detection of the following sexually transmitted diseases: hepatitis $B$; syphilis; AIDS; trichomoniasis; Chlamydia infection, gonorrhea and the presence of the human papillomavirus (HPV). Results: The participants' mean age was 26.1 years. Most of them had attended school for nine years or longer $(53.0 \%)$, were single $(71,6 \%)$, used contraceptives $(92.2 \%)$, denied having a history of previous STD $(77.5 \%)$ and reported to have had their first sexual relationship before they were 15 years old $(59.8 \%)$. Oral sex practice was mentioned by $90.2 \%$ of the women, and $37.3 \%$ of them reported to have anal sex. As regards prevention measures, $99 \%$ of the sex professionals reported to use condoms, and only $26.3 \%$ of the women who had a permanent partner reported its use in this case. The use of tobacco, alcohol and illegal drugs was high: $68.6 \%, 84.3 \%$ and $42.2 \%$, respectively. Oncotic cytology was normal for $95 \%$ of the women, since only five of them tested positive for some type of cellular alteration. $66.7 \%$ of the women had been immunized against Hepatitis B. The prevalence of STD was of $71.6 \%$. When considered isolatedly and in association, HPV $(67.7 \%)$ and Chlamydia infection $(20.5 \%)$ showed the highest prevalences. HPV typing showed the presence of oncogenic genotypes. Syphilis prevalence was of $4.0 \%$. No hepatitis B or gonorrhea cases were identified. Conclusions: The studied population consisted mostly of young adult women, with similar schooling to that of the average Brazilian population. Habits such as smoking, use of alcohol and illegal drugs were frequent. There was no association between STD, reported signs and symptoms and sociodemographic and behavioral variables related to the SP studied. In summary, the prevalence of STD in the studied group was high, since approximately two thirds of the women showed a disease of this type.

Key words: Infection; Women's Health; Prevalence; Nursing. 
1. INTRODUÇÃO 
Em diversos contextos em todo o mundo, e de maneira especialmente relevante nos países em desenvolvimento, as Doenças Sexualmente Transmissíveis (DST) constituem um dos principais determinantes da carga de doença das populações. As diferenças evidenciadas na prevalência, incidência e morbidade das DST podem ser compreendidas em função da disposição biológica em adquirir certas infecções/doenças, dos diferentes comportamentos sexuais que determinam aumento ou redução no risco de adquirir tais infecções e das dimensões culturais e sociais onde estão inseridos homens e mulheres (BASTOS et al., 2008 a).

Fatores demográficos também podem influenciar a ocorrência de DST, especialmente o grande número de jovens sexualmente ativos, mudanças socioculturais relacionadas à migração urbana, aumento do nível de prostituição e múltiplas parcerias sexuais, entre outros (FERREIRA et al., 2001; MAYAUD e MABEY, 2004).

Estudo realizado pela American Social Health Association (ASHA) investigou 1.155 adultos no ano de 2004, entre 18 e 35 anos, avaliando os seus conhecimentos e atitudes frente às DST. Mostrou que 93\% das pessoas acreditam que os seus parceiros sexuais atuais ou recentes não têm nenhuma DST, somente um, em cada três pesquisados, conversa com o parceiro a respeito de DST e menos da metade deles aborda o tema DST durante consulta médica. Disseram estar bem informados sobre os riscos associados ao sexo $63 \%$ e entre os adultos solteiros, $71 \%$ não usam nenhuma proteção quando fazem sexo oral, $42 \%$, no sexo anal e $23 \%$ tiveram sexo vaginal sem proteção (FOX, 2004).

Devido a diversas características, as DST podem evoluir por tempo prolongado de forma assintomática, fazendo com que na expressão de Eng e Butller, 1997, constituam "epidemia oculta", apenas perceptível na sua real extensão e gravidade por meio de estudos de base populacional (BASTOS et al., 2008 a).

É imprescindível que serviços de saúde, não somente os especializados na área incorporem a sua prática ações de prevenção e assistência às 
populações mais vulneráveis, de forma a assegurar sua institucionalização e consequente sustentabilidade, promovendo políticas intersetoriais para 0 sucesso de ações resolutivas (BRASIL, 2002).

Determinados órgãos registram dados sobre doenças em geral, como o Sistema de Informação dos Agravos de Notificação. Entretanto, os dados armazenados não abrangem a totalidade das DST, pois apenas a infecção pelo vírus HIV em gestantes e crianças, sífilis congênita e em gestantes e a aids são notificadas no Brasil. Compulsoriamente, desde 1982 foram identificados 54.965 casos de DST, dos quais 10.337 entre jovens de 13 a 19 anos e 44.628 entre adultos jovens, de 20 a 24 anos. Conforme apontam dados da Organização Mundial de Saúde (OMS), ocorrem no Brasil cerca de 12 milhões de DST ao ano e, segundo estimativa, cerca de 200 mil casos/ano são subnotificados, visto que $70 \%$ dos acometidos não recorrem diretamente aos serviços de saúde, pois buscam formas alternativas de cura (AQUINO et al., 2008).

No Brasil, embora campanhas educativas promovidas pelos órgãos federais, estaduais e municipais responsáveis pela saúde pública, enfatizem a prevenção, nos últimos 10 anos tem se verificado um aumento na incidência das DST, sobretudo em adolescentes e adultos jovens, demonstrando a mudança do comportamento sexual nesta população, com destaque para o surgimento da prostituição infanto-juvenil, exigindo controle mais rigoroso dos casos diagnosticados e dos contatos sexuais, bem como educação sexual voltada para os jovens e adolescentes (CASTRO et al.,2000).

Até o final de 2007, cerca de 3 milhões de pessoas viviam com HIV no continente americano. $\mathrm{Na}$ sua mais recente atualização epidemiológica, realizada em 2007, a UNAIDS (Joint United Nations Programme on HIVIAIDS) e a OMS estimaram que na América Latina e região do Caribe a proporção de infecção por grupo de risco foi de $26 \%$ entre homens que fazem sexo com homens; $19 \%$ entre usuários de drogas injetáveis (UDI); 13\% clientes de profissionais do sexo (PS); $4 \%$ em PS feminino e 38\% em outros grupos não especificados (GARCIA-CALLEJA et al., 2009). 
As DST são o maior problema de saúde pública entre mulheres, especialmente em países em desenvolvimento (SHETAWALA et al., 2009) e as desigualdades de gênero reforçam esta vulnerabilidade ampliada às mulheres (BASTOS et al., 2008a). As PS são as que apresentam maior risco para o desenvolvimento dessas doenças, trazendo diversos danos à saúde da mulher. Pesquisas recentes indicam que as DST ulcerativas e não ulcerativas podem ser cofatores para o HIV, fazendo com que o entendimento da prevalência dessas doenças na população interfira positivamente no planejamento de ações em Saúde Pública (SHETAWALA et al., 2009).

A aids, a princípio, enquadrava-se no conceito de grupos de risco. A partir dos anos 1980, porém, os casos de aids na população em geral aumentaram significativamente e, desse modo, a sociedade esqueceu tal conceito. Em decorrência de pressões externas de uma sociedade machista, na qual prevaleciam as desigualdades de gênero, com oferta de melhores empregos e educação para o sexo masculino, a mulher teve, ao longo dos anos, menos acesso a informações relacionadas às doenças vinculadas ao sexo (AQUINO et al., 2008).

Desde então, as mulheres tornaram-se alvos potenciais para a aquisição da doença e, consequentemente, diminuiu a disparidade entre os casos em homens e mulheres. Em virtude de carregar papel histórico vinculado a fatores biológicos, sociais e individuais, o ser-mulher apresenta maior vulnerabilidade em relação ao ser-homem (SCHAURICH e PADOIN, 2004).

Especificamente quanto à infecção pelo Vírus da Imunodeficiência Humana (HIV), as mulheres são mais suscetíveis, devido às mudanças hormonais, fisiológicas, ecologia da microbiota vaginal e maior prevalência de outras DST (QUINN, 2005); as regras de pareamento sexual e afetivo, que colocam em interação, habitualmente, homens mais velhos e mulheres mais jovens (GREGSON, 2002) e aos constrangimentos à adoção e manutenção das medidas de proteção sexual por parte das mulheres, inseridas em contextos de franca desigualdade de gênero, quando não de violência (FRANÇA JUNIOR et al., 2008). 
Diversas intervenções que visam às PS, associando o diagnóstico e tratamento das DST com a promoção do uso de preservativo, foram conduzidas nos países em desenvolvimento e têm provado sua eficácia na redução da incidência do HIV/aids e/ou taxas de DST entre estes grupos denominados de alto risco (SABIDÓ et al., 2009).

Estudos sugerem que as ofertas de assistência em DST podem ser viáveis e eficazes em ambientes de atenção primária. Além disso, seu controle é um elemento-chave, como parte essencial no pacote da saúde (SABIDÓ et al., 2009). No entanto, a integração da prevenção em DST e serviços de assistência em contextos de saúde é um desafio no controle dessas doenças (MAYAUD e MABEY, 2004).

Historicamente o sistema de saúde não incorpora a atenção às populações mais vulneráveis, como as PS, caracterizadas como de difícil acesso e com necessidades muito particulares. Com o aumento das ações de prevenção em DST/aids, o acesso destes segmentos aos serviços tem se ampliado, aliado a um forte estímulo para que essa população mais vulnerável procure os serviços de saúde (BRASIL, 2002).

Na sociedade brasileira, a sexualidade feminina está atrelada à condição biológica com fins reprodutivos e associada à tradicional estrutura familiar e, portanto, à maternidade. Assim, a prostituição é vista como atividade contrária às regras sociais, pois a busca pelo prazer irrestrito é o principal motivo da procura pela clientela. Além disso, as mulheres expressam sua sexualidade de forma explícita, em desrespeito aos limites impostos pela sociedade conservadora (AQUINO et al., 2008).

Manter relação sexual com vários homens, não escolher o parceiro e cobrar pelos serviços constitui prática milenar, que tradicionalmente tem subvertido o exercício controlado da sexualidade por instituições sociais. Tentativas de controle foram realizadas no passado, variando da satanização, isto é, o controle exercido pelas instituições religiosas, passando pela proibição expressa em códigos civis e chegando aos dias atuais com demanda por sua 
legalização como atividade profissional (BRASIL, 2002; GUIMARÃES e MERCHÁN-HAMANN, 2005).

A prostituição não consiste apenas em relação de troca entre sexo e dinheiro, mas também se pode trocar relações sexuais por favorecimento profissional, bens materiais e informações. De modo geral, a figura da prostituta remete à doença e sempre esteve vinculada à transmissão das DST, sobretudo em face da multiplicidade de parceiros (AQUINO et al., 2008). Verifica-se, ainda, que a prostituição é considerada pela sociedade como degradação moral e, sendo o sexo sua matéria- prima de trabalho, fica explícita a necessidade de medidas preventivas.

Profissional do sexo está inserida na Classificação Brasileira de Ocupações, documento que descreve as características das ocupações de acordo com o mercado de trabalho (BRASIL, 2009) e, assim, não é ilegal no Brasil. Contudo, subterfúgios, como o atentado ao pudor ou o escândalo público, têm sido utilizados como álibis para o enquadramento legal deste exercício. Diante deste fato, não se pode perder de vista as questões específicas que envolvem os diferentes sujeitos inseridos na cena do comércio sexual, como homens, mulheres, crianças e adolescentes (GUIMARÃES e MERCHÁN-HAMANN, 2005).

Para o êxito das ações de promoção à saúde, as PS do sexo devem ser consideradas sujeitos ativos, cabendo aos serviços de saúde buscar estratégias que promovam a adoção de comportamentos protetores, reduzindo situações de riscos e vulnerabilidade, contrapondo-as aos grupos nodais, constituídos por pessoas que fazem sexo sem proteção e com múltiplos parceiros (BOTELHO, 2003).

O sucesso internacional da resposta brasileira de enfrentamento ao HIV/aids e demais DST tem sido reconhecido, em decorrência da política de acesso universal à prevenção, ao diagnóstico e tratamento e da qualidade das informações disponíveis, sobretudo de estudos e pesquisas de várias áreas do conhecimento, evidenciando o subsídio para diversas estratégias governamentais nesse campo, o que se mostra extremamente relevante. Uma 
parcela significativa desses novos conhecimentos é gerada por profissionais de saúde dedicados à investigação em serviço, resultando em produtos e processos inovadores de interesse do Sistema Único de Saúde - SUS (POSSAS, 2007).

Outra tendência de investigações nacionais neste campo está relacionada a estudos comportamentais, que possibilitam a elaboração de cenários e melhor delineamento de tendências, tornando-se insumo essencial e indispensável à formulação de políticas voltadas à promoção da saúde e prevenção primária em DST/aids (CHEQUER, 2007).

O Programa Nacional de DST/aids, no contexto da epidemia, inclui as PS como um dos coletivos com necessidades específicas. Vale destacar que as ações junto a essa população, somada às pesquisas realizadas em nível nacional, vêm tentando ampliar o conhecimento sobre a realidade da prostituição feminina no país (GUIMARÃES e MERCHÁN-HAMANN, 2005).

Diante do exposto, justificam-se a realização de estudos que contribuam com a construção de novas iniciativas e parcerias na assistência a populações mais vulneráveis, especialmente as profissionais do sexo.

\subsection{Profissionais do Sexo: construção social, preconceito e legislação}

Por datar de tempos imemoriais, a prostituição facilmente adquire caráter natural, fazendo-nos prescindir de análises ou explicações mais sofisticadas. Apesar de constituir-se em prática milenar, debates sobre o tema têm permanecido restritos ao campo discursivo repressor e à criminalidade. No entanto, a legitimidade da profissão exige reflexão, e não apenas voltada a processos legais para sua inserção como mais uma categoria no sistema formal de trabalho (GUIMARÃES e MERCHÁN-HAMANN, 2005).

No início da epidemia HIVIAIDS, as prostitutas foram alvo de ações governamentais, que ora desejavam regulamentar a profissão, ora 
implantavam a ideia de abolição destas. O objetivo era controlar a prostituição, e até mesmo impedir o exercício pleno dos direitos das prostitutas, as quais foram consideradas culpadas por disseminar o HIV. Há tempos, vários países vêm observando as vantagens e desvantagens da regulamentação, proibição ou tolerância da prostituição. Porém, as perspectivas adotadas são incoerentes, uma vez que muitos países reconhecem a indústria do sexo, mas tornam ilegais todos os aspectos relacionados a ela, como a gerência desse trabalho (AQUINO et al., 2008).

No Brasil, o movimento das PS começou em 1979, no centro da cidade de São Paulo, na região conhecida como Boca do Lixo. Nesta época, as mulheres estavam sendo presas, agredidas e torturadas indiscriminadamente sob ordem e supervisão de policiais. O resultado deste cenário foi a morte de dois travestis e de uma mulher grávida, motivando a organização de passeata que mobilizou, inclusive, a sociedade civil e artistas famosos (BRASIL, 2002).

Vários anos se passaram até que, em julho de 1987, realizou-se na cidade do Rio de Janeiro (RJ), o primeiro Encontro Nacional de Prostitutas, que teve cobertura da mídia brasileira e internacional, tornado possível iniciar a formação da Rede Brasileira de PS, com sede neste Estado, assim como promover a criação de associações regionais a serem implantadas no restante do país. Participam desta rede 17 associações registradas em cartório e 65 grupos. O movimento é bastante dinâmico e estão surgindo novas associações, núcleos e grupos nas mais remotas cidades do país (BRASIL, 2002).

Um vínculo metafórico entre a prostituição e a transmissão de DST foi construído, em decorrência de práticas repressivas exercidas pelo Estado e efetivadas pelas autoridades de saúde, com o reforço de instituições policiais (GUIMARÃES e MERCHÁN-HAMANN, 2005). Deste modo, as DST justificaram a repressão, tendo como base discursiva a medicina higienista, que fundamentava seus pressupostos na busca do bem-estar da população (CARRARA, 1994). 
Com relação à epidemia de aids no Brasil, seu surgimento entendido como fenômeno associado a grupos de risco, coincide com o período de grande mobilização e início da luta pela conquista dos direitos civis e políticos das PS. O princípio político do movimento se deu a partir da autorrepresentação e autodeterminação, buscando a legalização da profissão como prioridade na agenda política (SERAFIM et al., 2002).

O debate sobre a legalização da prostituição está sendo colocado para a sociedade desde a apresentação do Projeto de Lei 98/2003 ao Congresso Nacional. O objetivo deste projeto é assegurar as condições de remuneração dos serviços prestados, como direito à carteira assinada, aposentadoria e assistência médico-hospitalar, buscando garantir os direitos das PS (GUIMARÃES e MERCHÁN-HAMANN, 2005).

$\mathrm{O}$ ato de prostituir-se, embora não seja considerado crime, revela-se como prática criminalizada, já que seu conteúdo se encontra imerso em contravenção, uma vez que o Código Penal prevê punição a todo aquele que contribui, incentiva, ou retira algum proveito do negócio sexual. Assim, no Brasil a situação é controversa, pois tudo o que se refere à gerência deste trabalho é ilegal, mas, ser prostituta e prostituir-se não o são. Isso dificulta a organização das PS por direitos políticos e segurança profissional (BRASIL, 2002).

O conhecimento sobre a realidade das PS pode permitir o entendimento da cena da prostituição não mais como o locus do mal necessário em relação a sua causalidade, mas sim como espaço onde se estabelecem diferentes códigos de vivência e conivência, bem como de emoções e afetividade (GUIMARÃES e MERCHÁN-HAMANN, 2005).

Compreender a prostituição como fenômeno social, complexo, multifacetado e heterogêneo é indispensável, pois ele é produto da conjunção de fatores sociais, econômicos, culturais e pessoais que inviabilizam a construção de um modelo explicativo único, criando estereótipos que auxiliam setores conservadores da sociedade a lidar com a questão (BRASIL, 2002).

Nessa perspectiva, em que pesam as dificuldades oriundas do estigma para a vida dessas mulheres, há que se pensar na riqueza de códigos ou 
classificações existentes na cena da prostituição. É ali que as PS organizam a forma de interação para enfrentar o que lhes é posto, visando ao exercício de sua profissão (NAUSSBAUM, 2002).

Com vistas à quebra de estigmas e preconceitos, deve-se pensar em uma nova política institucional, lutando pela eliminação de todas as leis específicas sobre prostituição, acreditando que as leis que a regem devem ser as mesmas que regem a todos os outros cidadãos, sem discriminação, anulando-se a posição de vítima e entrando em cena a pessoa/profissional, com direitos e deveres, responsável pela sua opção de vida (BRASIL, 2002).

\subsection{Prevalência das Doenças Sexualmente Transmissíveis no Brasil e no mundo}

As DST pela sua transcendência, vulnerabilidade, magnitude e factibilidade de controle, devem ser priorizadas enquanto agravos de saúde pública, sendo consideradas ações básicas a interrupção da cadeia de transmissão e a prevenção de novas ocorrências (BRASIL, 2006a).

Nos últimos anos, principalmente após o início da epidemia de aids, as DST readquiriram importância como problema de saúde pública. Dentro do contexto da atenção às DST em nosso país, existem fatos negativos, como a escassez de dados epidemiológicos, a discriminação de seus portadores nos vários níveis do sistema de saúde, a pequena acessibilidade de populações prioritárias, como as PS e a inadequação do atendimento, resultando em segregação e exposição a situações de constrangimento e em irregularidade na disponibilização de medicamentos específicos, fatos que contribuem para o descrédito dos serviços de saúde (BRASIL, 2006a).

As DST são consideradas atualmente o principal facilitador da transmissão sexual do HIV. Grande parte das pessoas infectadas desconhece seu estado de portador, o que constitui um elo importante na cadeia de transmissão, ajudando a perpetuar o ciclo de maneira ainda mais silenciosa. 
Outro fator extremamente relevante é a falta de informação ou dificuldade de acesso aos serviços de saúde, o que resulta muitas vezes na opção pelo tratamento em farmácias ou a automedicação, encobrindo-se sua verdadeira prevalência e impedindo a interrupção na cadeia de transmissão (BRASIL, 2006b).

As DST atingem silenciosamente milhões de pessoas em todo mundo. Dentre aquelas passíveis de cura, no ano de 1999, a Organização Mundial de Saúde (OMS) estimou a ocorrência de 340 milhões de casos novos no mundo, na faixa etária entre 15 e 49 anos, sendo que no Brasil esta estimativa foi de aproximadamente 12 milhões de casos novos/ano. Nos países em desenvolvimento, as DST não curáveis, como herpes genital (HSV-2), Papiloma Vírus Humano (HPV), Hepatite B e HIV, respondem por $17 \%$ das perdas econômicas com o binômio saúde-doença (PINTO, 2007).

O controle das DST é tarefa árdua, por questões culturais e de gênero, relacionadas aos comportamentos sexuais, aos altos índices de infecções assintomáticas em mulheres e à dificuldade de acesso aos testes para diagnóstico laboratorial, muitos deles de elevado custo (LINHARES et al., 2004). Porém, após o reconhecimento da transmissão sexual do vírus HIV e a identificação do papel das DST ulcerativas ou não como fator de risco para sua transmissibilidade e de outras doenças, evidenciou-se a necessidade de ampliar o painel de investigação para diagnóstico e tratamento precoce dos casos.

Em estudo realizado em 2005, com mulheres PS chinesas, 86,5\% delas já tinham ouvido falar em HIV/aids, mas seus conhecimentos foram relativamente pobres sobre o assunto (DING et al., 2005), reforçando a concepção de que educação, triagem e tratamento das DST podem ser uma eficaz intervenção em saúde pública para reduzir a transmissão do HIV (WANG et al., 2009). Quando perguntado a essas mulheres sobre seu risco pessoal de ser infectada pelo vírus HIV, $81 \%$ responderam que não havia nenhuma possibilidade ou "não sei" (DING et al., 2005). Na África, outro estudo indagou sobre o conhecimento das PS sobre HIV e $85 \%$ responderam ter algum 
conhecimento, mas 60\% não utilizavam medidas de proteção (HARIJAONA et al., 2009).

Além de agirem como cofator para a aquisição e transmissão do HIV, exercendo papel fundamental na dinâmica de sua transmissão em todo o mundo (BOILY e ANDERSON, 1996; QUINN, 1996), alguns vírus de transmissão sexual desempenham também importante papel na ocorrência de cânceres secundários. Nesse sentido, o HPV está associado a diversos cânceres, com destaque para os de colo de útero e de ânus e, como recentemente evidenciado, das amígdalas e outras regiões da cabeça e pescoço e o vírus da hepatite $\mathrm{B}(\mathrm{HBV})$ pode conduzir a quadros de cirrose, insuficiência hepática e carcinoma hepático (HOBBS et al., 2006).

A infecção clamidiana tem incidência variada no Brasil. Estudos realizados em grupos populacionais diversos e utilizando metodologias variadas, demonstram uma oscilação entre 2,1\% e 31,5\% (MARQUES e MENEZES, 2005).

A Coordenação do Programa Nacional de DST/aids do Ministério da Saúde estima a ocorrência de 1.967 .200 casos novos de Chlamydia trachomatis (CT) a cada ano, verificando-se uma incidência de 3,5\% no sexo feminino e 2,3\% no masculino. As estimativas do Centro de Controle de Doenças dos Estados Unidos da América (CDC-EUA), mostram que esta infecção está disseminada e existem mais casos novos dela do que de qualquer outra DST, inclusive sífilis, gonorréia, HPV, herpes e aids (PASSOS et al., 2003) Estudo entre adolescentes encontrou amostra positiva para CT entre meninos assintomáticos de 5,3\%, revelando ser o parceiro masculino um importante reservatório para as infecções que ocorrem no sexo feminino (GAYDOS et al., 1998).

Em outros estudos, as prevalências obtidas variaram de 2,4\% (EGGETKRUSE et al., 2003), 4,2\% (COOK et al., 2002), 5,5\% (FOLCH et al., 2009), 8,6\% (Shields et al., 2004), 10\% (GILLE e KLAPP, 2007), 12\% (HARIJAONA et al., 2009) e 37,4\% (LEE et al., 2006), sendo essa infecção mais frequente em 
mulheres (SHIELDS et al., 2004) e associada à doença inflamatória pélvica (DAYAN, 2006).

Idade inferior a 25 anos, início precoce da atividade sexual, multiplicidade de parceiros sexuais, não uso de preservativo nas relações sexuais, uso de contraceptivos hormonais orais por mulheres jovens, nuliparidade, uso de ducha vaginal, presença de ectopia cervical, hábito de fumar, passado de DST e baixo nível educacional, são fatores de risco que se associam à infecção por CT (MARQUES e MENEZES, 2005).

A infecção clamidiana é assintomática em $70 \%$ das mulheres e pode ser detectada no colo uterino, uretra, ductos e glândulas de Bartholin, cavidade uterina, tubas e mucosa retal (FRIAS et al., 2001; MIRANDA et al., 2003), assim, esse microorganismo pode ser considerado bem adaptado ao ser humano, uma vez que consegue multiplicar-se sem causar respostas exacerbadas do organismo, daí as dificuldades para o seu diagnóstico (BRASIL, 1999; WORLD HEALTH ORGANIZATION, 2001; FRIAS et al., 2001).

O diagnóstico clínico, muito impreciso pela falta de sinais e sintomas na maioria dos casos, é obtido laboratorialmente, pesquisando-se a CT em cultura de células, imunofluorescência direta, ELISA e reação em cadeia da polimerase (FRIAS et al., 2001; MIRANDA et al. 2003). Essa infecção é reconhecida como uma das mais frequentes DST de origem bacteriana no mundo (MANAVI, 2006). A CT é um parasita intracelular obrigatório, com genoma pequeno, membrana externa semelhante à de outras bactérias Gramnegativas e deficiente na produção de ATP endógeno (SCHACHTER, 1999). Apresenta ciclo de desenvolvimento bifásico e, por essa razão, existem duas formas celulares, os corpúsculos elementar e reticular (ANDREWS et al., 2006). Sua virulência mantém relação com seu ciclo de desenvolvimento celular, o qual inclui as fases de internalização, proliferação/diferenciação e saída (SCHACHTER, 1999).

Nos serviços públicos brasileiros, os locais que oferecem sistematicamente a pesquisa da CT são raros. Nos serviços privados, normalmente esta pesquisa se dá em casos sintomáticos ou quando um dos 
parceiros sexuais está acometido. Mesmo nessas situações, a pesquisa da CT ainda não faz parte da rotina da maioria dos ginecologistas, urologistas ou médicos que atendem DST, apesar da sua importância e possível relação com o câncer de colo uterino (BRASIL, 1999; CODES et al., 2002; CODES et al., 2006).

A associação da CT com Neisseria gonorrhoeae (NG) é frequente e deve fazer parte da investigação, considerando a gravidade das complicações que essas infecções podem provocar (FRIAS et al., 2001; MIRANDA et al. 2003).

A NG é um diplococo Gram-negativo, não flagelado, não formador de esporos, anaeróbio facultativo e que na bacterioscopia corada pelo método de Gram é visualizado com duas estruturas reniformes justapostas, quase sempre agrupadas, no citoplasma de neutrófilos (TRABULSI, 2005). Dados sobre a frequência desse microrganismo são escassos no Brasil. São poucos os estudos avaliando essa cervicite, sendo os dados nacionais inconsistentes. Esta infecção, no entanto, é prevenível e/ou tratável e o prognóstico depende da precocidade da instituição do tratamento. Atualmente, sua importância aumentou muito, por ser facilitadora da infecção pelo HIV (RAMOS et al., 2003).

A gonorreia figura como um dos mais antigos estados mórbidos da humanidade e com a utilização dos antimicrobianos em sua terapêutica no início da década de 1930, a resistência a esses fármacos desenvolveu-se rapidamente, evidenciando que uma boa estratégia de combate e controle de determinada morbidade bacteriana deve prever um programa de vigilância epidemiológica estadiando o comportamento de sensibilidade dos agentes etiológicos, entre outros procedimentos (BELDA JúNIOR et al., 2002).

A NG também é transmitida sexualmente e pode ser assintomática, já que entre $30 \%$ a $80 \%$ das mulheres com esta cervicite não apresentam qualquer sintomatologia. Com frequência, a prevalência e a incidência dessa infecção são mais altas entre as adolescentes, mesmo quando possuem parceiro único. Assim, a escolha do parceiro e o comportamento deste podem 
ser elementos mais importantes do que o comportamento pessoal de risco, no que diz respeito à alta prevalência desta DST entre as mulheres (CODES Et al., 2006).

A gonorreia e outras DST têm taxas elevadas em populações específicas. Estudo com trabalhadoras do sexo, homens e transgêneros, em São Francisco, Califórnia, relatou as seguintes taxas: gonorreia $(12,4 \%)$, infecção clamidiana $(6,8 \%)$, sífilis $(1,8 \%)$ e herpes $(34,3 \%)$ (COHAN et al., 2006). Entre mulheres PS, alguns autores relatam taxa de $22 \%$ no Senegal (LAURENT et al., 2003) e na China, 36,8\% (XU et al., 2008). Após intervenção, também na China, a prevalência de gonorreia diminuiu de $26 \%$ para $4 \%$ (ROU et al., 2007). No Brasil, estudo realizado em seis capitais em 2005, evidenciou taxa de $1,5 \%$ entre gestantes, $0,9 \%$ entre homens trabalhadores da indústria e $7,4 \%$ entre indivíduos atendidos em clínicas de DST, sendo 18,5\% em homens e 3,3\% em mulheres (BRASIL, 2008b).

Entre PS peruanas, recrutadas nas ruas ou em bordéis, a prevalência de CT foi de $22 \%$ e de NG $14 \%$, utilizando-se amostras de urina para detecção destes micro-organismos. Essas mulheres tinham mais de 10 parceiros por semana e trabalhavam com o comércio sexual há mais de cinco anos em bordéis. Houve associação entre idade e infecção, sendo que as adolescentes apresentaram maior risco. A maioria delas relatou não saber se estava em situação de risco e não houve associação significativa entre autopercepção de risco e prevalência de DST. Os autores, considerando a elevada taxa de infecção, a falta de conhecimento sobre as DST/HIV/aids, a avaliação de risco para DST e outros comportamentos de risco predominantes nesta população, sugerem a necessidade de programas de intervenção nesta população (PARIS et al., 1999). Outros estudos encontraram as seguintes prevalências de NG: 0,5\% na Espanha (FOLCH et al., 2009) e na Índia as prevalências variaram de acordo com o local de trabalho das PS: 5,4\% entre as trabalhadoras em bordéis e 2,6\% entre aquelas que trabalhavam na rua (BUZDUGAN et al., 2009). 
A infecção genital pelo HPV é a DST de origem viral mais frequentemente diagnosticada no mundo, acometendo cerca de $30 \%$ da população ativa, prevalência esta que varia de $8,7 \%$ a $72 \%$, dependendo da população e do método diagnóstico empregado (STRAND et al., 1993; OKESOLA e FAWOLE, 2000; SHIN et al., 2004; TABORA et al., 2005; GAJEWSKA et al., 2005). Alguns grupos, como portadores de HIV, indivíduos com antecedentes de tratamento para HPV e profissionais do sexo, têm maior incidência e prevalência (MAGI et al., 2006).

Entre PS coreanas, a presença do HPV foi de $83,5 \%$, sendo que os principais genótipos de alto risco do HPV foram 16, 18, 56 e 58 e os principais genótipos de baixo risco foram 6 e 11 (YUN et al., 2008).

As vias de transmissão do HPV podem ser sexual, não sexual (familiar ou nosocomial por fômites) ou materna-fetal, esta última podendo ser gestacional, intra e periparto. Porém, a via sexual representa a grande maioria dos casos. Com relação à via não sexual, é provável que o HPV, assim como as verrugas cutâneas, possa ser transmitido por "fômites" (toalhas e roupas íntimas, entre outros) e, também, pelo instrumental ginecológico, quando não esterilizado adequadamente (PEREYRA e PARELLADA, 2003). Segundo esses autores, existe associação entre idade do início de atividade sexual, número de parceiros e maior prevalência de infecção pelo HPV, fatores estes freqüentemente presentes entre mulheres PS.

Os HPVs são vírus DNA de dupla hélice circular, pertencentes à família Papovaviridae. Estão descritos mais de 120 tipos que infectam homens e mulheres, com diferentes repercussões clínicas (GRCE et al., 2000; GUO et al. 2006). O estudo dos genótipos de HPV alavancou a possibilidade de pesquisas científicas e de triagem do risco de oncogênese nos pacientes portadores de infecção genital por este vírus, temática extensivamente investigada nos últimos anos (CASTLE et al., 2006; GARGIULO et al., 2007; KULMALA et al., 2007).

Considerando o modo similar de transmissão, vários trabalhos sugerem que o HPV e a C. trachomatis têm papel central no desenvolvimento de lesões 
precursoras do câncer cervical (TAMIN et al., 2002; GOLIJOW et al., 2005). A infecção por CT é um cofator do HPV no desenvolvimento da neoplasia intraepitelial cervical (NIC), possivelmente pela modulação da imunidade do hospedeiro e/ou presença de inflamação crônica (TAMIN et al., 2002). Sabe-se, porém, que a presença do HPV isoladamente não é suficiente para a carcinogênese cervical e que outras DST podem aumentar o risco de desenvolvimento de lesões precursoras ou de carcinoma invasor, em conjunto com a infecção pelo HPV (PAAVONEN e LEHNTINEM, 1999).

A tricomoníase vaginal (TV) é uma DST causada pelo Trichomonas vaginalis, protozoário flagelado, que atinge rapidamente o parasitismo com sucesso em um ambiente hostil, através de vários mecanismos pelos quais estabelece sua patogenicidade e também sua capacidade de invadir o sistema imune do hospedeiro. Pode apresentar ampla variedade de manifestações clínicas, desde quadro assintomático até uma severa vaginite.

A OMS estima prevalência mundial superior a 170 milhões de casos de infecção por TV anualmente e, com isso, a tricomoníase, junto com as infecções por clamídia, gonorreia e sífilis, representa uma clássica DST curável e que está longe de ser um problema de saúde pública em via de solução (PASSOS, 2006). Na Europa, é responsável por $41 \%$ dos casos de vaginite (MACIEL et al., 2004). No Rio de Janeiro, Brasil, estudo com 112 mulheres com queixas de corrimento vaginal, diagnosticou, por meio de citologia oncótica, 9 casos (8\%) de tricomoníase (PASSOS et al., 2002).

Alguns estudos mostram a correlação do TV com a infecção pelo HIV, com predisposição à doença inflamatória pélvica, câncer cervical e infertilidade (RIVERO et al., 2002; FICHOROVA, 2009) Para seu diagnóstico é necessário o exame microscópico a fresco do conteúdo vaginal ou a cultura em meio de Diamonds, considerado padrão-ouro (RADONJIC et al., 2006).

Diversos estudos realizados com mulheres PS e com diferentes metodologias demonstram variadas prevalências de TV. No Paraná, Brasil, encontrou-se prevalência de 3,9\% (CORREA et al., 2008); na Guatemala, estudo realizado entre 2005 e 2008, após intervenção, identificou que a 
prevalência diminuiu de 6,8\% em 2005 para 4,8\% em 2008 (SABIDÓ et al., 2009); na China, dependendo do meio diagnóstico, a prevalência variou de $13,6 \%$ a $14,4 \%$, quando se utilizou exame a fresco ou cultura de Whittington, respectivamente (THAKOR et al., 2004); em Dakar, Senegal, encontrou-se 22,4\% (Laurent et al., 2003) e em Madagascar, na África, 32\% (HARIJAONA et al., 2009). Em Niterói, Brasil, a taxa entre 124 mulheres acompanhadas pela Estratégia Saúde da Família foi de 5,6\% (PASSOS et al., 2007b).

Algumas DST não estão relacionadas ao desenvolvimento de infecções genitais, embora sejam igualmente relevantes. É o caso da aids e da Hepatite B.

Reconhecida oficialmente como doença infecciosa transmissível pelo CDC em 1981, a aids desde então se constitui num grande desafio para a saúde pública. Desde 1994 há relatos de que a epidemia poderia ser adquirida por qualquer pessoa, uma vez que os comportamentos de risco apresentam-se na sociedade como um todo (GIR et al., 2005).

A infecção pelo HIV e a aids constituem fenômeno global, dinâmico e instável, resultante das profundas desigualdades existentes na sociedade brasileira. Sua propagação revela uma epidemia de diversas dimensões, que está sofrendo transformações epidemiológicas significativas. Se no início limitava-se aos grandes centros urbanos e atingia marcadamente a população masculina, atualmente caracteriza-se pelos processos de heterossexualização, feminização, interiorização e pauperização (BRITO et al., 2001). Estima-se que esta epidemia cresce nove vezes mais entre as mulheres, configurando-se o cuidado feminino problema de saúde pública (AMARO, 2005).

No Estado de São Paulo, do ano de 1994 até a introdução dos antirretrovirais na rede pública de saúde, em 1997, a aids configurou-se como primeira causa de morte entre mulheres de 20 a 35 anos de idade. A razão de casos masculinos e femininos vem diminuindo rapidamente, estando atualmente numa proporção de 2:1. Assim, é imprescindível considerar que a vulnerabilidade das mulheres à epidemia de HIV é decorrente do conjunto das características macropolíticas, econômicas e socioculturais que reforçam ou 
diluem seu risco individual (FIGUEIREDO e AYRES, 2002), sendo importante a adoção de estratégias de prevenção mais efetivas voltadas a esse grupo (SILVEIRA et al., 2002).

Desde o início dessa epidemia, as PS apresentam alta prevalência de infecção por HIV e, por este motivo, muitas vezes têm sido responsabilizadas pela sua disseminação (SILVA et al., 2007). Este grupo está especialmente vulnerável a adquirir o HIV (GIRALDO et al., 2005) e, neste sentido, o frequente desequilíbrio da microbiota vaginal a que estão sujeitas pode ser fator relevante. Considerando que as mulheres que apresentam alteração da flora vaginal podem tornar-se mais vulneráveis à aquisição do HIV, fica fácil entender que o equilíbrio do meio vaginal reveste-se de especial importância na proteção do indivíduo contra este tipo de DST.

Em estudo realizado com PS da cidade de Santos, a prevalência do HIV variou em função da saúde sexual, do uso de substâncias psicoativas e das práticas sexuais. A prevalência entre as mulheres com sorologia positiva para sífilis foi de $21 \%$; para aquelas com cicatriz sorológica, $16 \%$, e entre as que se declararam usuárias de cocaína, crack ou drogas injetáveis, 11\%, 17\% e 37\%, respectivamente (SILVA et al., 2007). Na China, encontrou-se taxa de 0,3\% do vírus HIV, utilizando-se para diagnóstico exame realizado do fluido oral, atribuindo a baixa prevalência ao reduzido consumo de drogas injetáveis: 0,8\% (DING et al., 2005). Na Espanha, a prevalência entre PS foi de 1,8\% (FOLCH et al., 2009) e no Senegal foi 6,0\% (LAURENT et al., 2003).

A Hepatite B é uma doença infecciosa do fígado causada pelo vírus da hepatite B. É o maior problema de saúde pública mundial, sendo que atualmente mais de 350 milhões de pessoas estão cronicamente infectadas pelo vírus da hepatite $B$, o qual é transmitido diretamente através do sexo inseguro e sangue contaminado, sendo 50 a 100 vezes mais contagioso do que o vírus HIV (BAARS et al., 2009).

As primeiras provas de que a hepatite B poderia ser transmitida pela via sexual remonta o início dos anos 70 do século passado, com o vírus isolado da saliva, vagina e sêmen, sendo frequentemente detectado em pacientes 
atendidos em clínicas de DST. Em estudo realizado em população portadora do HIV, a prevalência encontrada foi de 40,9\%, evidenciando semelhanças dos fatores envolvidos na transmissão deste vírus e do HIV (CHAVEZ et al., 2003). Situação semelhante foi identificada em estudo realizado em Ribeirão Preto/SP, com 401 indivíduos infectados pelo HIV, onde a prevalência global dos marcadores para a Hepatite B foi 40,9\% (SOUZA et al., 2004).

Ao avaliar-se a soroprevalência da hepatite B na América Latina, constatou-se que o Brasil é o único país que apresentou associação entre alta soroprevalência e baixo nível socioeconômico, sendo que as maiores vias de transmissão foram a sexual, o estilo de vida e comportamentos que oferecem maior risco, como uso de drogas injetáveis e relações sexuais sem uso de preservativo (CHAVEZ et al., 2003).

Os estudos relativos à aids, iniciados a partir de 1980, constituíram fato decisivo para os trabalhadores do sexo serem investigados com mais frequência para Hepatite $B$, devido à semelhança dos mecanismos de transmissão e, consequentemente, informações acerca do comportamento e aspectos biológicos relacionados com a transmissão desta infecção. No Brasil, as investigações sobre a Hepatite B e PS são escassas, prejudicando o conhecimento sobre a situação epidemiológica neste grupo populacional (PASSOS e FIQUEIREDO, 2004; PASSOS, 2007a).

Apesar da disponibilidade de vacina segura e eficaz contra hepatite B por mais de duas décadas, a incidência global da doença continua grande (FORBI et al., 2008). Em estudo realizado na Holanda, investigou-se a cobertura vacinal e o conhecimento de 259 PS sobre o programa de imunização gratuita, sendo que $79 \%$ das mulheres relataram a consciência da oportunidade de obter a vacinação contra hepatite B e $63 \%$ relataram ser vacinadas contra essa doença, demonstrando que informações e intervenções podem mudar o quadro atual da doença, devendo ser otimizadas campanhas de vacinação, principalmente para populações em situações de risco (BAARS et al., 2009). 
Na Nigéria, onde estudos demonstram que a hepatite $B$ é endêmica, a prevalência obtida desta doença entre 720 mulheres PS foi de $17,1 \%$, sendo que neste país as PS não são submetidas a controle preventivo para infecção da hepatite $B$. Os autores concluem o estudo recomendando que a vacinação seja considerada fundamental entre este grupo (FORBI et al., 2009).

A transmissão do vírus da hepatite B se faz por via parenteral e, sobretudo, pela via sexual, sendo considerada uma DST. Dessa forma, pode ser transmitida através de solução de continuidade (pele e mucosas), relações sexuais desprotegidas e por via parenteral (compartilhamento de seringas e agulhas, tatuagens, colocação de piercing, intervenções odontológicas e/ou cirúrgicas); por transmissão vertical (mãe-filho); pelo aleitamento materno e por acidentes perfurocortantes. A cronificação da doença ocorre em aproximadamente $5 \%$ a $10 \%$ dos adultos infectados (BRASIL, 2008a).

Os sintomas da hepatite $\mathrm{B}$, quando presentes, são inespecíficos, predominando fadiga, mal-estar geral e sintomas digestivos. Somente 20 a $40 \%$ dos casos têm história prévia de hepatite aguda sintomática. Em uma parcela dos casos crônicos, após anos de evolução, pode aparecer cirrose, com surgimento de icterícia, edema, ascite, varizes de esôfago e alterações hematológicas. A hepatite B crônica pode também evoluir para hepatocarcinoma sem passar pelo estágio de cirrose (BRASIL, 2008a).

Certamente as pesquisas sorológicas entre PS devem incluir a sífilis, seja para rastreamento, seja para diagnóstico. A sífilis é causada pelo Treponema pallidum, transmitido pelo contato íntimo entre parceiros sexuais, por meio de exposição parenteral, sangue ou instrumentos contaminados e disseminação hematogênica transplacentária. No Brasil, tem-se grande dificuldade de estimar a prevalência da sífilis, pela falta de uniformização diagnóstica. Porém, dados obtidos entre gestantes, indicam incidência entre $1,5 \%$ e $5,6 \%$ (BRASIL, 2006 b).

A sífilis ainda é um grande desafio para a saúde pública no Brasil. Apesar de sua história natural ser conhecida, a avaliação complementar diagnóstica estar disponível, com elevada sensibilidade e custos baixos, ter 
tratamento eficaz, com custo reduzido e grande experiência de uso, sua prevalência ainda é alta. Além disso, no caso da sífilis congênita, a população alvo das intervenções frequenta os serviços de saúde em diferentes momentos de sua vida. No caso da sífilis adquirida, as ações de abordagem sindrômica na rede de serviços públicos de saúde representam estratégia importante para a cobertura à sua atenção, além das outras DST (BRASIL, 2006 b).

Na China, em estudo realizado com 362 PS, encontrou-se associação entre a presença de sífilis e o uso inconsistente do preservativo com clientes, menor escolaridade e infecção pelo vírus HIV, sendo a prevalência desta doença de 11\% (LU et al., 2009). Estudo realizado com 100 PS em Madagascar, África, encontrou $11 \%$ de prevalência para sífilis (HARIJAONA et al., 2009). Na Índia, entre trabalhadoras em bordéis, encontrou-se prevalência de $3,5 \%$ e entre as trabalhadoras na rua $6,7 \%$. No Senegal, a prevalência foi de $23,8 \%$ (LAURENT et al., 2003).

As profissionais do sexo apresentam característica singular de manterem atividade sexual intensa, com grande quantidade de coitos por dia, acrescida do risco decorrente do uso de substâncias químicas locais e de eventuais microtraumatismos vaginais, com provável perturbação do ecossistema vaginal (GIRALDO et al., 2005). Assim, representam uma população de alto risco para as DST, não apenas pela intensa prática sexual, mas também por situações a ela associadas, como o consumo de drogas ilícitas e de bebidas alcoólicas, a exposição a prisões, o baixo nível educacional e a marginalização socioeconômica.

Em contrapartida, devido ao estigma a que são expostas, as PS têm recebido pouca atenção por parte dos órgãos de saúde e pesquisadores no Brasil, resultando na carência de informações que permitam um melhor conhecimento de aspectos ligados aos riscos a que são submetidas, essenciais para orientação de programas preventivos (PASSOS e FIQUEIREDO, 2004; PASSOS, 2007a).

O controle efetivo das DST, virais, parasitológicas e bacterianas, continua sendo um problema, principalmente na América Latina, pois apesar do 
desenvolvimento tecnológico, as estimativas continuam crescendo exponencialmente (BENZAKEN et al., 2007). Serviços de rastreamento de DST devem ser oferecidos em locais onde exista concentração de grupos de risco para que a detecção dessas doenças e o seu tratamento imediato se traduzam na redução dos problemas por elas causados à comunidade (CODES et al, 2006).

Pelo exposto, dois aspectos relativos às DST merecem ser ressaltados: 1- sua elevada prevalência entre mulheres, em geral, aponta para a necessidade de expansão dos métodos de detecção e 2- ainda são relativamente escassos estudos brasileiros de prevalência entre as populações consideradas de risco, o que poderia contribuir com a identificação de estratégias de intervenção mais adequadas, fato que justifica a realização desta investigação, voltada ao estudo das DST em PS. 
2. OBJETIVOS 


\subsection{Objetivo geral}

Identificar a prevalência de DST entre profissionais do sexo do município de Botucatu e verificar a associação destas a fatores de risco sociodemográficos e comportamentais.

\subsection{Objetivos específicos}

- Descrever as características sociodemográficas, os antecedentes ginecológicos, obstétricos, sexuais e de DST da população incluída no estudo;

- Descrever, na população de estudo, sinais e sintomas atuais relacionados às DST e suas características quanto aos hábitos de vida e comportamento sexual de risco e de proteção às DST;

- Identificar a prevalência das DST entre as profissionais do sexo a partir de exames considerados padrão-ouro;

- Identificar as possíveis associações entre DST e sinais e sintomas ginecológicos referidos pelas profissionais do sexo incluídas no estudo;

- Identificar possíveis associações entre DST e variáveis sociodemográficas e comportamentais relativas à população estudada. 
3. MÉTODO 


\subsection{Desenho do Estudo e Local de Realização}

Trata-se de estudo epidemiológico transversal, de vigilância populacional, voltado à identificação da prevalência de DST na população feminina de profissionais do sexo de Botucatu, município de médio porte, localizado na região central do Estado de São Paulo, com população estimada de 120.800 habitantes e área de unidade territorial de $1.483 \mathrm{Km}^{2}$ (IBGE, 2007). O serviço público de atenção básica de Botucatu é constituído por Policlínicas, Centros Municipais de Saúde, Centros de Saúde Escola e Unidades de Saúde da Família (Figura 1).

Ressalta-se que em Botucatu o combate à epidemia de aids é considerado prioritário, tendo sido implantado o programa municipal de DST/aids em 2002. A equipe de trabalho é composta por uma coordenadora e quatro agentes estratégicos de prevenção. Conforme proposto pelo programa estadual, o município busca realizar ações voltadas à diminuição da vulnerabilidade da população em relação às DST/HIV/aids, à melhoria da qualidade de vida das pessoas afetadas e à redução do preconceito, da discriminação e dos demais impactos sociais negativos das DST/HIV/aids, através de políticas públicas pautadas pela ética e compromisso com a promoção da saúde e da cidadania, em consonância com os princípios do SUS.

Os agentes estratégicos de prevenção atuam junto à coordenação do programa, identificando o território onde vivem diversos grupos populacionais vulneráveis e fatores que contribuem para a exposição da comunidade frente ao HIV/aids e a outras DST.

Especificamente com relação às PS, o Programa prevê a visita mensal a todos os locais de trabalho cadastrados, para entrega de preservativo, orientações voltadas à promoção da saúde e encaminhamentos em casos de identificação de problemas para as Unidades de Saúde. Como ações programáticas, realizam-se campanhas para coleta de citologia oncótica tríplice, vacinação contra hepatite B e coleta de exames sorológicos para 
identificação de DST. Em momentos especiais, como no Dia Mundial da Luta Contra a Aids, realizam-se ações voltadas ao rastreamento e diagnóstico desta doença neste grupo de mulheres.

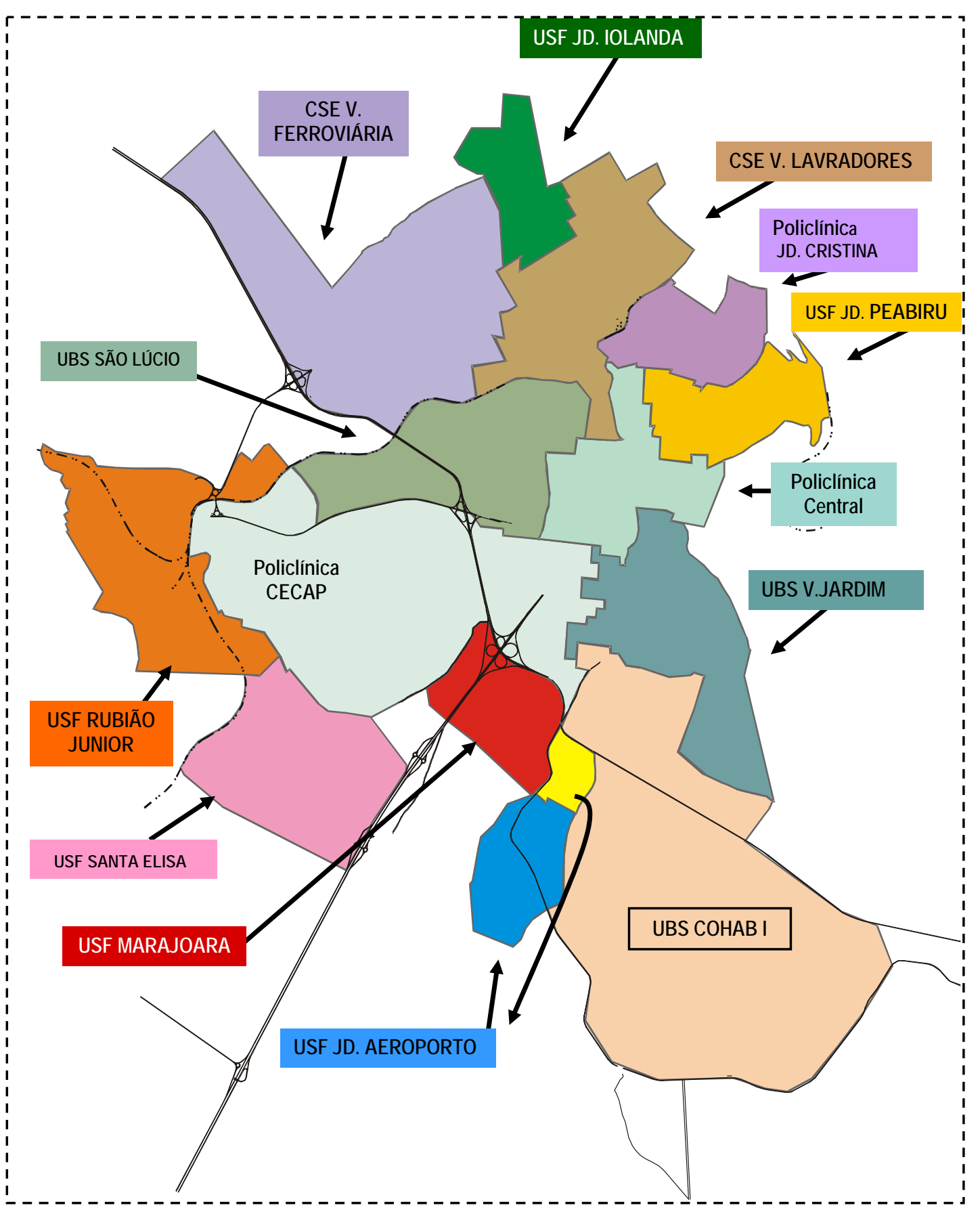

Fonte: Secretaria Municipal de Saúde de Botucatu (Modificado).

Figura 1- Mapa com as áreas de abrangência das Unidades Básicas de Saúde e de Saúde da Família de Botucatu, 2007. 


\subsection{População de Estudo}

A população de mulheres PS do município estudado muda de local de trabalho frequentemente, o que permite caracterizá-la como flutuante. Por essa razão, para definição do grupo de estudo, dois critérios foram adotados: 1definição do período de coleta de dados, entre agosto de 2008 e março de 2009 e 2- realização de pelo menos três visitas em cada um dos seis locais de permanência das mulheres, dos quais três eram casas, três prostíbulos e duas chácaras. Assim, foram identificadas 107 profissionais do sexo, sendo incluídas no estudo 102 (95,3\%) e excluídas cinco (4,7\%): duas devido à recusa na coleta de sangue periférico para os exames sorológicos e três devido ao extravio do resultado do exame de citologia oncótica.

\subsection{Coleta de conteúdo vaginal, secreção cervical e sangue}

As coletas de conteúdo vaginal, secreção cervical e sangue foram realizadas nos locais onde as PS exercem a sua profissão e são acompanhadas pelos Agentes Estratégicos de Prevenção do Programa Municipal DST/aids.

Inicialmente, solicitava-se espaço físico, geralmente um quarto, para montagem da sala de coleta com mesa ginecológica, foco de luz e mesa auxiliar, além de todos os materiais necessários para a coleta. Em seguida, a mestranda abordava as PS, informando sobre a realização do trabalho, convidando-as a participar do estudo e realizando o Aconselhamento pré-teste em DST/aids. Após o consentimento das mesmas, quatro agentes estratégicas do Programa DST/aids previamente capacitadas faziam a entrevista para coleta de dados, garantindo-se privacidade e anonimato das mulheres participantes do estudo. Durante a entrevista, utilizou-se instrumento próprio, construído especificamente para o estudo, com 38 questões relativas a dados socioeconômicos, comportamentais e antecedentes de imunização, 
ginecológicos, obstétricos e sexuais (Anexo 1). Considerou-se que as informações obtidas pelas agentes estratégicas seriam mais fidedignas, devido ao vínculo que possuem com as PS.

Após a entrevista, a mulher era direcionada para a coleta de sangue periférico $(10 \mathrm{ml})$, através de punção venosa, sendo o material acondicionado em tubos de ensaio estéreis, Vacuntainer (Beckton Dickinson, Rutherford, NJ, USA) ${ }^{\circledR}$. Três auxiliares de enfermagem capacitados revezaram-se nesta atividade. Posteriormente, as amostras de sangue coletadas para diagnóstico de sífilis e Hepatite B eram encaminhadas ao Laboratório Clínico e para diagnóstico do HIV ao Hemocentro do Hospital das Clínicas da Faculdade de Medicina de Botucatu.

Em seguida, a PS era encaminhada para exame ginecológico, também realizado pela pós-graduanda. Utilizou-se o espéculo bi-valvo de Collins descartável, esterilizado e isento de qualquer lubrificante. Após esse procedimento, foram anotadas as características macroscópicas do conteúdo vaginal, seguindo-se a mensuração do $\mathrm{pH}$ com fita $\mathrm{Merck}^{\circledR}$, graduada entre quatro e sete, comprimida contra o terço médio da parede vaginal lateral durante um minuto, procedendo-se à leitura de acordo com instruções do fabricante. Depois, coletou-se conteúdo da parede lateral vaginal com zaragatoa estéril e foram adicionadas duas gotas de $\mathrm{KOH} \mathrm{10 \%} \mathrm{para} \mathrm{realização}$ do whiff test. Coletou-se, então, com espátula de Ayre, conteúdo do fundo de saco vaginal, semeado em meio líquido de Diamonds para pesquisa de Trichomonas vaginalis, sendo o material coletado mantido em temperatura entre 36 e $37^{\circ} \mathrm{C}$ até a chegada no Laboratório de Imunologia da Reprodução Humana do Departamento de Patologia da Faculdade de Medicina de Botucatu, da Universidade Estadual Paulista, onde foi acondicionado em estufa a $37^{\circ} \mathrm{C}$.

A secreção cervical para pesquisa de Chlamydia trachomatis, Neisseria gonorroheae e Papilomavírus Humano foi colhida com cytobrush. O raspado cervical para pesquisa de $C$. trachomatis e HPV foi acondicionado em tubo Falcon de $15 \mathrm{~mL}$ com $1000 \mu \mathrm{L}$ da solução de Tris-HCl 50mM pH 8,5 / EDTA 
$1 \mathrm{mM} \mathrm{pH} 8,0$ (TE) e armazenado a $-20^{\circ} \mathrm{C}$ até o momento do processamento no Laboratório de Imunologia da Reprodução Humana do Departamento de Patologia da Faculdade de Medicina de Botucatu. A presença de $C$. trachomatis na secreção cervical foi avaliada pela técnica de Reação em Cadeia da Polimerase (PCR). Para o HPV, foram empregadas as técnicas de PCR e tipagem por PCR multiplex. Para pesquisa de $N$. gonorrhoeae, a secreção cervical foi semeada em meio de Thayer Martin, sendo as placas acondicionadas em jarra de anaerobiose e encaminhadas para 0 processamento no Laboratório de Bacteriologia do Departamento de Microbiologia e Imunologia do Instituto de Biociências da Universidade Estadual Paulista, também em Botucatu.

Citologia Oncótica Tríplice (COT) foi colhida em lâmina de extremidade fosca, dividida em três partes, para realização de esfregaço contendo células do fundo vaginal, região escamo-colunar e endocérvice. O material foi fixado e transportado ao Laboratório de Citopatologia do Departamento de Patologia da Faculdade de Medicina de Botucatu.

O transporte de todo o material coletado foi realizado pela pesquisadora, no máximo três horas após a coleta, ao término do período de trabalho.

\subsection{Variáveis Estudadas}

Neste estudo, foram incluídas variáveis sociodemográficas; antecedentes obstétricos, ginecológicos e de imunização; queixa e achados ao exame ginecológico e fatores comportamentais, conforme segue:

- Sociodemográficas: idade (anos), escolaridade (nenhuma, fundamental, médio, universitário), estado civil (casada, solteira, união estável, divorciada/separada);

- Antecedentes obstétricos: número de partos (nenhum, um, dois, três, quatro, cinco, seis ou mais), número de abortos (nenhum, um, dois, três, quatro, cinco, seis ou mais); 
- Imunização: vacina contra hepatite B (sim, não, não sabe);

- Antecedentes ginecológicos: método contraceptivo (não usa, hormonal oral, hormonal injetável, dispositivo intrauterino, preservativo masculino, preservativo feminino, laqueadura, outro), menarca (10 a 15 anos, 16 anos ou mais), coitarca (10 a 15 anos, 16 a 21 anos, 22 a 27 anos, acima de 27 anos), DST (sim, não), tipo de DST, ano da última coleta de COT (antes de 2000, 2001, 2002, 2003, 2004, 2005, 2006, 2007, 2008), sangramento após relação sexual (sim, não);

- Queixa ginecológica: corrimento vaginal (sim, não), tempo (menos de sete dias, entre oito e trinta dias, mais de trinta dias, não percebe corrimento), aspecto (fluido, pastoso, bifásico, bolhoso, não percebe corrimento), cor (amarelo, branco, esverdeado, acinzentado, não percebe corrimento), odor (sim, não, às vezes, não percebe corrimento), prurido (não, sim, às vezes, não percebe corrimento), sintomas urinários (sim, não) tipo de sintoma urinário;

- Fatores comportamentais: sexo oral (sim, não), sexo anal (sim, não), ducha vaginal (sim, não), tampão vaginal (sim, não), preservativo no trabalho (sim, não), preservativo com parceiro fixo (sim, não, não tem parceiro fixo), número de parceiros na última semana (até cinco, seis a 11, 12 a 17, mais de 17), horas passadas desde a última relação sexual (até 24 , de 25 a 48, de 49 a 72, mais de 72), uso de antibiótico no último mês (sim, não) tipo de antibiótico utilizado, fuma (sim, não) número de cigarros por dia, usou drogas (sim, não), tipo de droga que usou (maconha, cocaína, crack, outras, não usou), uso atual de drogas (sim, não), tipo de droga que usa (maconha, cocaína, crack, outras, não usa), ingestão de álcool (sim, não);

- Achados ginecológicos ao exame: corrimento vaginal (sim, não), aspecto (fluido, pastoso, bifásico, outros), cor (amarelo, branco, acinzentado, outros), whiff-test (presente, ausente, duvidoso), $\mathrm{pH}$ vaginal $(>=4,5 \mathrm{e}$ $<4,5)$, localização da junção escamo-colunar $(0,-1,-2,-3)$. 


\section{Resultados dos exames realizados}

- Doenças sexualmente transmissíveis: hepatite $B$ (reagente, não reagente), sífilis (reagente, não reagente), anti-HIV (reagente, não reagente), CT (positiva, negativa), TV (positivo, negativo), NG (positiva, negativa), HPV (positivo, negativo), genótipos em caso de HPV positivo $(6 / 11,16,18,33$ e 45);

- Resultado da COT: negativo para neoplasia, lesão intraepitelial de baixo grau, lesão intra-epitelial de alto grau, células escamosas atípicas de significado indeterminado (possivelmente não neoplásicas), células escamosas atípicas de significado indeterminado (não se pode afastar lesão intraepitelial de alto grau).

\subsection{Procedimentos Técnicos Relacionados aos Exames Realizados}

\subsubsection{Pesquisa de CT e HPV: extração do DNA com solução CTAB (cetyltrimethylammonium bromide)}

No momento do processamento, após descongelamento do material, à secreção cervical foi adicionada proteinase $\mathrm{K}$ na concentração final de 400 $\mu \mathrm{g} / \mu \mathrm{l}$. As amostras foram incubadas a $56^{\circ} \mathrm{C}$ durante 3 horas para a digestão do material e, após esse período, a proteinase $\mathrm{K}$ foi inativada por aquecimento a $96^{\circ} \mathrm{C}$ durante 7 minutos.

Após a digestão do material, foram adicionados $100 \mu \mathrm{l}$ de uma solução de $\mathrm{NaCl} 5 \mathrm{M}$. Em seguida, $100 \mu$ da solução $\mathrm{CTAB} / \mathrm{NaCl}$ pré-aquecida a $65^{\circ} \mathrm{C}$ foi adicionada, com posterior incubação por 10 minutos a $65^{\circ} \mathrm{C}$. Após a incubação foi acrescentado $750 \mu \mathrm{l}$ de clorofórmio - álcool isoamílico 24:1 centrifugado em seguida por 5 minutos 13.000 rpm à temperatura ambiente. $O$ sobrenadante foi então transferido para novo tubo e adicionado $450 \mu \mathrm{l}$ de 
etanol absoluto a $-20^{\circ} \mathrm{C}$ com posterior incubação por 10 minutos nessa mesma temperatura. Em seguida, o material foi novamente centrifugado por 15 minutos, $13.000 \mathrm{rpm}$ a $4^{\circ} \mathrm{C}$, o sobrenadante descartado e acrescentado $450 \mu \mathrm{l}$ de etanol $70 \%$ a temperatura ambiente. Após centrifugação por 15 minutos, $13.000 \mathrm{rpm}$ a $4^{\circ} \mathrm{C}$ e descarte do sobrenadante, as amostras foram colocadas em estufa a $56^{\circ} \mathrm{C}$ por 15 minutos e em seguida ressuspensas em $50 \mu \mathrm{l}$ de tampão TE para posterior utilização na detecção do DNA através das técnicas de PCR e tipagem por PCR multiplex.

Para amplificação do Ácido Nucleico (PCR), inicialmente, em sala de pré-PCR previamente esterilizada por luz ultravioleta durante 15 minutos, foram preparados todos os master mixes, em volume final de $25 \mu \mathrm{L}$, composto por 2,5 $\mu \mathrm{L}$ de PCR Buffer 10x (Invitrogen); 2,0 $\mu \mathrm{L}$ de $\mathrm{MgCl}_{2}$; 0,5 $\mu \mathrm{L}$ DNTP mix 20mM; $0,25 \mu \mathrm{L}$ de Taq DNA Polimerase (Platinum, Invitrogen); $1,25 \mu \mathrm{L}$ de cada primer na concentração de $10 \mu \mathrm{M} ; 15,25 \mu \mathrm{L}$ de água Milli-Q autoclavada (Milli Q Plus, Milipore) e $2 \mu \mathrm{L}$ de cada amostra pesquisada. As incubações foram realizadas em termociclador Eppendorf Mastercycle Personal.

Para pesquisa de $C$. trachomatis, foram utilizados os primers PCT1 e PCT2 (CASTLE et al., 2006), empregando-se os parâmetros de $95^{\circ} \mathrm{C}$ durante 1 minuto para desnaturação, $55^{\circ} \mathrm{C}$ durante 1 minuto para anelamento dos primers e $72^{\circ} \mathrm{C}$ por 1 minuto e 30 segundos para extensão, seguido de mais 39 ciclos idênticos ao descrito, e extensão final a $72^{\circ} \mathrm{C}$ por 5 minutos. Em todas as reações realizadas, foi utilizado um controle negativo, através da substituição do ácido nucléico por água Milli-Q autoclavada e um controle positivo contendo DNA extraído de células McCoy infectadas por $C$. trachomatis.

Para pesquisa de HPV foram utilizados os primers GP5+ e GP6+ (DE RODA HUSMAN et al., 1995) empregando-se os parâmetros de $95^{\circ} \mathrm{C}$ durante 5 minutos e $95^{\circ} \mathrm{C}$ durante 45 segundos para desnaturação, $47,7^{\circ} \mathrm{C}$ durante 45 segundos para anelamento dos primers e $72^{\circ} \mathrm{C}$ durante 1 minuto para polimerização, seguido de mais 44 ciclos idênticos ao descrito. Finalizando, a temperatura de extensão final será de $72^{\circ} \mathrm{C}$ por 7 minutos e resfriamento a $4^{\circ} \mathrm{C}$. Em todas as reações realizadas, foi utilizado um controle negativo, através da 
substituição do ácido nucléico por água Milli-Q, e um controle positivo contendo DNA de HPV extraído de células HeLa.

A extração do DNA das amostras estudadas foi verificada pela amplificação do gene constitutivo da $\beta$-globina empregando-se os primers PCO4 e GH20 e os parâmetros previamente descritos (GOLIJOW et al., 2005). Para todas as análises, foram consideradas apenas as amostras que foram positivas para $\beta$-globina.

Os produtos de PCR foram submetidos à eletroforese em gel de agarose 1,5\% (Invitrogen) preparada em tampão Tris-Ácido Bórico-EDTA (TBE) 1X e corada com Brometo de Etídio (Gibco BRL). O tamanho dos produtos amplificados foram comparados com o padrão de 50 pb e 100 pb (GE Healthcare) e visualizados sob transiluminação ultravioleta.

Para a determinação dos tipos virais presentes nas amostras que apresentaram positividade para DNA de HPV foi empregada a técnica de PCR multiplex. Foram utilizados primers específicos para os tipos 6/11, 16, 18 (VAN DEN BRULE et al., 1990). As reações foram realizadas em tubos pra PCR de $0,2 \mathrm{~mL}$ em volumes totais de $20 \mu \mathrm{L}$, contendo $0,6 \mu \mathrm{L}$ de cada primer na concentração de $10 \mu \mathrm{M}, 10 \mu \mathrm{L}$ de GoTaq $^{\circledR}$ Green Master Mix (Promega), 4,4 $\mu \mathrm{L}$ de água Milli-Q autoclavada e $2 \mu \mathrm{L}$ da amostra de DNA. Os parâmetros utilizados foram $94^{\circ} \mathrm{C}$ durante 5 minutos e $94^{\circ} \mathrm{C}$ durante 1 minuto para desnaturação, $53,5^{\circ} \mathrm{C}$ durante 30 segundos para anelamento dos primers e $72^{\circ} \mathrm{C}$ durante 1 minuto para polimerização, seguido de mais 37 ciclos idênticos ao descrito. Finalizando, a temperatura de extensão final foi de $72^{\circ} \mathrm{C}$ por 7 minutos e resfriamento a $4^{\circ} \mathrm{C}$.

Também foi realizada a pesquisa de HPV33 através de PCR primerespecífico (VAN DEN BRULE et al., 1990). Em cada reação, foram utilizados $0,6 \mu \mathrm{L}$ de cada primer na concentração de $10 \mu \mathrm{M}, 10 \mu \mathrm{L}$ de $\mathrm{GoTaq}^{\circledR}$ Green $^{\circ}$ Master Mix (Promega), 6,8 $\mu \mathrm{L}$ de água Milli-Q autoclavada e $2 \mu \mathrm{L}$ da amostra de DNA. Os parâmetros utilizados foram $94^{\circ} \mathrm{C}$ durante 4 minutos e $94^{\circ} \mathrm{C}$ durante 1 minuto para desnaturação, $45^{\circ} \mathrm{C}$ durante 1 minuto para anelamento dos primers e $72^{\circ} \mathrm{C}$ durante 1 minuto para polimerização, seguido de mais 37 ciclos 
idênticos ao descrito. Finalizando, a temperatura de extensão final foi de $72^{\circ} \mathrm{C}$ por 7 minutos e resfriamento a $4^{\circ} \mathrm{C}$.

Em todas as reações realizadas, foi utilizado um controle negativo, através da substituição do ácido nucléico por água Milli-Q, e um controle positivo contendo clones de DNA de HPV específicos para cada um dos tipos virais estudados.

\subsubsection{Pesquisa de Neisseria gonorrhoeae}

Foi utilizada a semeadura direta no meio de cultura específica, com incubação entre $35^{\circ} \mathrm{C}$ a $37^{\circ} \mathrm{C}$, em atmosfera de $\mathrm{CO}_{2}$, imediatamente após a coleta da amostra. O citobrush era espraiado no ágar Thayer Martin (acrescido de $3 \mathrm{mg} / \mathrm{ml}$ de vancomicina, $7,5 \mathrm{mg} / \mathrm{ml}$ de colistina, $13,5 \mathrm{mg} / \mathrm{ml}$ de nistatina e 5 $\mathrm{mg} / \mathrm{ml}$ de trimetropim, além do suplemento de nutrientes Vitox, Oxoid) e a placa era colocada em jarra de anaerobiose, numa atmosfera enriquecida com $\mathrm{CO}_{2}$, que era obtida com o auxílio de uma vela. No tempo máximo de 5 horas, a jarra era colocada em estufa de $\mathrm{CO}_{2}$ a $37^{\circ} \mathrm{C}$, por até 72 horas. Se não houvesse crescimento após esse período, a cultura era considerada negativa. Se ocorressem colônias características, eram realizados testes presuntivos como coloração pelo método de Gram (diplococos Gram negativos), catalase a 3\% (positiva) e prova de superoxol (peróxido de hidrogênio a 30\%). Testes confirmatórios incluem verificação da produção de ácido a partir da glicose, maltose, lactose, sacarose e frutose, além da redução de $\mathrm{NO}_{3}$ (KONEMAN et al. 2001; JANDA e GAYDOS 2007).

\subsubsection{Pesquisa de Trichomonas vaginalis}

A pesquisa de TV foi realizada em meio líquido de Diamonds, seguida de incubação à temperatura de $37^{\circ}$ e leitura diária no período de 5 dias. 


\subsubsection{Citologia oncótica tríplice}

As lâminas encaminhadas ao Laboratório de Citopatologia foram colocadas em berço de coloração e mergulhadas em álcool 95\% overnight. Em seguida, passaram pela etapa de hidratação, colocadas em cubas de álcool em concentrações decrescentes e preparadas para receberem o corante nuclear Hematoxilina de Harris, durante um minuto ou mais, dependendo da necessidade. Após esse procedimento, as lâminas foram lavadas em água corrente e mergulhadas em cubas de álcool em concentrações crescentes, para receberem a contracoloração citoplasmática, que corresponde aos corantes Orange G e EA/36. Após estas etapas, as lâminas sofreram processo de desidratação, sendo mergulhadas em cubas com álcool absoluto e diafanização, sendo mergulhadas em cubas contendo xilol. Após esta última etapa, as lâminas estavam prontas para serem montadas com lamínula e resina sintética. Como resultado do processo de coloração, as células eosinofílicas apresentam citoplasma vermelho, laranja ou róseo; as células cianofílicas, citoplasma azul ou esverdeado e o núcleo apresentam coloração azul, violeta escuro ou marrom. As lâminas foram examinadas por citotécnicos e médicos citopatologistas, de acordo com o Sistema Bethesda (SALOMOND et al., 2002).

\subsubsection{Sorologias}

As amostras de sangue periférico coletadas foram enviadas ao laboratório clínico e hemocentro da FMB, onde sofreram centrifugação durante 10 minutos a 2000/rpm para obtenção do soro. Em seguida, foram realizados os exames específicos. 


\subsubsection{Pesquisa de Sífilis}

Como triagem, a pesquisa do Treponema pallidum foi feita através do teste de floculação Veneral Disease Reseach Laboratry (VDRL), do laboratório Wiener lab $^{\circledR}$ (suspensão antigênica estabilizada para realizar a prova VDRL modificada - USR - de detecção de sífilis, segundo orientações do fabricante). O teste confirmatório do Treponema pallidum foi feito através da técnica de ELISA.

\subsubsection{Pesquisa do vírus da Hepatite B}

\section{Anti-HBs}

Foi usado o AxSYM AUSAB, imunoensaio enzimático por micropartículas (MEIA), para determinação quantitativa do Anticorpo para o Antígeno de Superfície do vírus da hepatite B (anti-HBs) em soro ou plasma humanos, no equipamento AXSYM system, da marca Abbott Laboratórios do Brasil LTDA ${ }^{\circledR}$, segundo orientações do fabricante.

\section{HBsAg}

Foi usado o ensaio ARCHITECT HBsAg, imunoensaio quimioluminescente por micropartículas (CMIA) para a determinação quantitativa de Antígeno de Superfície da Hepatite B (HBsAg) em soro e plasma humano, no equipamento AXSYM system, da marca Abbott Laboratórios do Brasil LTDA ${ }^{\circledR}$, segundo orientações do fabricante.

\subsubsection{Pesquisa do HIV}

Foi usado o ensaio MUREX HIV-1.2.0 enzimaimunoensaio para detecção de anticorpos contra o vírus da imunodeficiência humana tipos 1 (HIV-1, HIV-1 grupo O) e o HIV 2 em soro ou plasma humano, da marca Abbott Laboratórios do Brasil LTDA ${ }^{\circledR}$, segundo orientações do fabricante. 


\subsection{Análise dos Dados}

Foi construído banco de dados no sistema Excel, o qual permitiu o intercâmbio de informações com o software estatístico Epiinfo. Toda digitação foi realizada por mestranda da área de bioestatística e a consistência dos dados foi checada para verificação e comparação da distribuição de frequências em questões associadas, com correção dos erros identificados.

Para o estudo de associações, foi criada no Banco de Dados a variável presença de DST (sim, não). A análise estatística foi realizada a partir do teste qui quadrado $\left(x^{2}\right)$, fixando nível de significância $\alpha=0.05$, com o cálculo dos respectivos odds ratio e intervalo de confiança (IC 95\%).

\subsection{Procedimentos Éticos}

Este estudo foi avaliado e aprovado pelo Comitê de Ética em Pesquisa (CEP) da Faculdade de Medicina de Botucatu da Universidade Estadual Paulista "Júlio de Mesquita Filho" e respeitou todas as orientações para pesquisas envolvendo seres humanos (Anexo 2). As mulheres que concordaram em participar do mesmo assinaram Termo de Consentimento Livre e Esclarecido para Participação em Estudo Científico (Anexo 3).

Os resultados dos exames realizados foram informados às profissionais do sexo pela própria autora, todas as PS que tiveram DST diagnosticada neste estudo foram imediatamente tratadas ou encaminhadas para tratamento e aquelas que não eram vacinadas contra hepatite B foram orientadas a fazê-lo. 
4. RESULTADOS 
A caracterização das 102 PS estudadas evidencia que a média de idade foi 26,1 anos ( $\pm 6,8$ anos). A maioria delas relatou, no momento do estudo, ter o ensino médio incompleto ou completo $(53,0 \%)$ e ser solteira $(71,6 \%)$. Do total de mulheres, $54,0 \%$ relataram não ter filhos ou ter filho único. A história de abortamento esteve presente em $36,2 \%$ dos casos. Com relação à imunização contra Hepatite B, 29,4\% das mulheres não estavam imunizadas (Tabela 1).

Tabela 1. Variáveis sociodemográficas e antecedentes obstétricos e de imunização das profissionais do sexo $(n=102)$ estudadas. Botucatu, 2009.

\begin{tabular}{lcc}
\hline Variáveis & $\mathbf{N}^{\mathbf{0}}$ & $\%$ \\
\hline Escolaridade & 11 & 10,7 \\
0 a 4 anos & 37 & 36,3 \\
5 a 8 anos & 24 & 23,5 \\
9 a 10 anos & 30 & 29,5 \\
11 anos ou mais & & \\
Estado civil & 73 & 71,6 \\
Solteira & 13 & 12,7 \\
União Estável & 8 & 7,8 \\
Divorciada/Separada & 8 & 7,8 \\
Casada & & \\
Número de Partos & 27 & 26,5 \\
Nenhum & 28 & 27,5 \\
1 & 18 & 17,6 \\
2 & 17 & 16,7 \\
3 & 12 & 11,8 \\
4 ou mais & & \\
Número de Abortos & 65 & 63,8 \\
Nenhum & 24 & 23,5 \\
1 & 9 & 8,8 \\
2 & 3 & 2,9 \\
3 & 1 & 1,0 \\
4 & & \\
Vacina contra Hepatite B & 68 & 66,7 \\
Sim & 30 & 29,4 \\
Não & 4 & 3,9 \\
Não sabe informar & & \\
\hline
\end{tabular}


A maioria das mulheres teve a primeira menstruação e a primeira relação sexual (coitarca) antes dos 15 anos de idade: 94,2\% e 59,8\%, respectivamente. Em relação ao uso de método contraceptivo, 94 mulheres $(92,2 \%)$ faziam uso e, entre essas, as escolhas mais frequentemente relatadas foram preservativo masculino (38,3\%) e anticoncepcional hormonal associado à preservativo masculino ou feminino (30,9\%). Nenhuma PS relatou fazer uso somente do preservativo feminino. Com relação aos antecedentes de DST, foi relatado por 23 mulheres (22,5\%), sendo a doença mais referida o condiloma acuminado $(37,5 \%)$, seguido da sífilis $(16,7 \%)$ e herpes genital $(16,7 \%)$. Nunca tinham realizado o exame preventivo do câncer do colo do útero $8,8 \%$ das mulheres e, entre aquelas que haviam realizado este exame, 63,4\% referiram tê-lo feito entre os anos de 2007 2008. A maior parte das mulheres $(87,3 \%)$ negou história de sangramento vaginal após relação sexual (Tabela 2). 
Tabela 2. Antecedentes ginecológicos das profissionais do sexo $(n=102)$ estudadas. Botucatu, 2009.

\begin{tabular}{lcc}
\hline Relatos & $\mathbf{N}^{\mathbf{0}}$ & $\mathbf{\%}$ \\
\hline Menarca (idade) & & \\
Até os 15 anos & 64,1 \\
Depois dos 15 anos & 6 & 5,9 \\
Coitarca (idade) & & \\
Até os 15 anos & 61 & 59,8 \\
Após os 15 anos & 41 & 40,2 \\
Uso de método contraceptivo & & \\
Sim & 94 & 92,2 \\
Não & 8 & 7,8 \\
Método contraceptivo usado (n=94) & \\
Preservativo masculino & 36 & 38,3 \\
Hormonal (oral ou injetável) e barreira & 29 & 30,9 \\
Hormonal (oral ou injetável) & 22 & 23,5 \\
Laqueadura & 5 & 5,3 \\
Preservativo feminino ou masculino & 1 & 1,0 \\
Dispositivo intra-uterino & 1 & 1,0 \\
Antecedentes de DST & & \\
Sim & 23 & 22,5 \\
Não & 79 & 77,5 \\
DST prévia (n=24) & & \\
Condiloma acuminado & 9 & 37,5 \\
Sífilis & 4 & 16,7 \\
Herpes genital & 4 & 16,7 \\
Outras (Hepatites B/C, TV, chato, cancro duro e associações) & 6 & 25,0 \\
História de coleta de Citologia Oncótica (CO) & & \\
Sim & 93 & 91,2 \\
Não & 9 & 8,8 \\
Ano da última coleta de CO (n=93) & & \\
2007 ou 2008 & 59 & 63,4 \\
2006 ou antes & 32 & 34,4 \\
Não sabe informar & 2 & 2,2 \\
História de sangramento após relação sexual & 13 & 12,7 \\
Sim & 89 & 87,3 \\
Não &
\end{tabular}


A queixa de corrimento vaginal esteve presente em $60,8 \%$ das entrevistadas, com as seguintes características: duração a menos de 30 dias da entrevista $(58,1 \%)$; de aspecto pastoso $(54,8 \%)$; com coloração branca $(66,1 \%)$; sem odor $(66,1 \%)$ ou prurido $(69,4 \%)$. Apresentaram queixa urinária 28 mulheres $(27,5 \%)$, em todos os casos disúria (Tabela 3 ).

Tabela 3. Queixa ginecológica e características, de acordo com as profissionais do sexo estudadas. Botucatu, 2009.

\section{Relatos \\ Corrimento $(\mathrm{n}=102)$}

$\mathrm{N}^{\circ} \%$

Sim

6260,8

Não

4039,2

Tempo de evolução $(n=62)$

Menos de 30 dias

3658,1

Mais de 30 dias

2641,9

Aspecto $(\mathrm{n}=62)$

Pastoso

3454,8

Fluído

1829,0

Outros (bifásico ou bolhoso)

1016,1

Cor $(n=62)$

Branco

Amarelo

1625,8

Outras (acinzentado, esverdeado e branco/amarelado)

$4 \quad 6,5$

Não sabe informar

11,6

Odor $(n=62)$

Sim

Não

Prurido $(n=62)$

Sim

1930,6

Não

Queixas urinárias $(n=102)$

Sim (disúria) 
Com relação aos hábitos comportamentais, todas as mulheres praticam sexo vaginal, $90,2 \%$ referiram praticar sexo oral e $37,3 \%$ sexo anal. A ducha vaginal é realizada por $64,7 \%$ delas e $50,0 \%$ usam tampão vaginal. Referiram uso de preservativo no trabalho $99,0 \%$ das PS, contudo, apenas $26,3 \%$ fazem uso do preservativo com parceiro fixo. Quanto ao número de parceiros nos sete dias que antecederam a inclusão no estudo, $72,5 \%$ das entrevistadas referiram até cinco parceiros. São tabagistas $68,6 \%$ das mulheres, $84,3 \%$ consomem álcool e 42,2\% drogas ilícitas (Tabela 4).

Tabela 4. Fatores comportamentais das profissionais do sexo $(n=102)$ estudadas. Botucatu, 2009

\begin{tabular}{lcc}
\hline Variáveis & $\mathrm{N}^{\circ}$ & $\%$ \\
\hline Sexo oral & 92 & 90,2 \\
Sim & 10 & 9,8 \\
Não & & \\
Sexo anal & 38 & 37,3 \\
Sim & 64 & 62,7 \\
Não & & \\
Ducha vaginal & 66 & 64,7 \\
Sim & 36 & 35,3 \\
Não & & \\
Tampão vaginal & 51 & 50,0 \\
Sim & 51 & 50,0 \\
Não & & \\
Uso de preservativo no trabalho & 101 & 99,0 \\
Sim & 1 & 1,0 \\
Não & & \\
Parceiro fixo* & 80 & 78,4 \\
Sim & 22 & 21,6 \\
Não & & \\
\hline
\end{tabular}


Tabela 4. Fatores comportamentais das profissionais do sexo $(n=102)$ estudadas. Botucatu, 2009 - Continuação.

\begin{tabular}{|c|c|c|}
\hline Variáveis & $\mathrm{N}^{\circ}$ & $\%$ \\
\hline \multicolumn{3}{|l|}{$\begin{array}{l}\text { Uso de preservativo (masculino ou feminino) com parceiro fixo } \\
(n=80)\end{array}$} \\
\hline $\operatorname{Sim}$ & 21 & 26,3 \\
\hline Não & 59 & 73,8 \\
\hline \multicolumn{3}{|l|}{ Número de parceiros nos últimos 7 dias } \\
\hline Nenhum & 2 & 2,0 \\
\hline Até 5 & 74 & 72,5 \\
\hline Mais de 5 & 26 & 25,5 \\
\hline \multicolumn{3}{|l|}{ Tabagismo } \\
\hline Sim & 70 & 68,6 \\
\hline Não & 32 & 31,4 \\
\hline \multicolumn{3}{|l|}{ Cigarros por dia $(n=70)$} \\
\hline Até 25 & 50 & 71,4 \\
\hline Mais de 25 & 20 & 28,6 \\
\hline \multicolumn{3}{|l|}{ Uso de álcool no trabalho } \\
\hline Sim & 86 & 84,3 \\
\hline Não & 16 & 15,7 \\
\hline \multicolumn{3}{|l|}{ História de uso de drogas ilícitas } \\
\hline $\operatorname{Sim}$ & 62 & 60,8 \\
\hline Não & 40 & 39,2 \\
\hline \multicolumn{3}{|l|}{ Tipo de droga que usou $(n=62)$} \\
\hline Maconha & 14 & 22,6 \\
\hline Cocaína & 14 & 22,6 \\
\hline Crack & 1 & 1,6 \\
\hline $\begin{array}{l}\text { Associações (maconha, cocaína, crack, lança-perfume, cola de sapateiro e } \\
\text { solventes) } \\
\text { Uso atual de drogas ilícitas }\end{array}$ & 33 & 53,2 \\
\hline $\operatorname{Sim}$ & 43 & 42,2 \\
\hline Não & 59 & 57,8 \\
\hline \multicolumn{3}{|l|}{ Tipo de droga que faz uso $(n=43)$} \\
\hline Cocaína & 13 & 30,2 \\
\hline Maconha & 9 & 20,9 \\
\hline Crack & 3 & 7,0 \\
\hline Associações (maconha, cocaína e crack) & 18 & 41,9 \\
\hline
\end{tabular}

* Relação sexual com envolvimento pessoal ou compromisso: namoro, noivado ou "caso" (amantes), sem qualquer forma de pagamento. 
Achados ginecológicos do exame especular evidenciaram que 55,0\% das mulheres tinham conteúdo vaginal, com as seguintes características: aspecto fluido $(58,9 \%)$ e de cor branca $(82,1 \%)$; teste das aminas positivo ou duvidoso $(56,9 \%), \mathrm{pH}$ vaginal alterado $(70,6 \%)$, sem ectopia $(74,5 \%)$, colo uterino friável ou sangrante à coleta $(10,8 \%)$ e com sinais de DST em $2,0 \%$ dos casos, sempre sugerindo condiloma acuminado (Tabela 5).

Tabela 5. Achados ginecológicos encontrados durante exame especular das profissionais do sexo estudadas. Botucatu, 2009.

\begin{tabular}{lcc}
\hline Variáveis & $\mathrm{N}^{\circ}$ & $\%$ \\
\hline Conteúdo vaginal (n=102) & 56 & 55,0 \\
Sim & 46 & 45,0 \\
Não & & \\
Aspecto do conteúdo vaginal (n=56) & 33 & 58,9 \\
Fluído & 17 & 30,4 \\
Pastoso & 6 & 10,7 \\
Outros (bifásico ou bolhoso) & & \\
Coloração do conteúdo vaginal (n=56) & 46 & 82,1 \\
Branco & 6 & 10,7 \\
Amarelo & 4 & 7,2 \\
Outros (marrom ou transparente) & & \\
Teste das aminas ou whiff test & 58 & 56,9 \\
Positivo/Duvidoso & 44 & 43,1 \\
Negativo & & \\
Aferição do PH vaginal & 72 & 70,6 \\
$>4,5$ & 30 & 29,4 \\
$<4,5$ & & \\
Ectopia & 26 & 25,5 \\
Sim & 76 & 74,5 \\
Não & & \\
Colo uterino friável ou sangrante & 11 & 10,8 \\
Sim & 91 & 89,2 \\
Não & & \\
Sinais sugestivos de DST & 2 & 2,0 \\
Sim (condiloma acuminado) & 100 & 98,0 \\
Não & & \\
\hline & &
\end{tabular}


A prevalência de DST nas profissionais do sexo analisadas foi de $71,6 \%$, sendo que, isoladamente, o HPV foi o agente mais frequente $(45,1 \%)$ e, considerando-se as associações, C. trachomatis e HPV (15,6\%). Não foi diagnosticado nenhum caso de infecção por Neisseria gonorrhoeae e nem de hepatite B. O HIV foi detectado em $1,0 \%$ das profissionais do sexo (Tabela 6).

Tabela 6. Ocorrência de DST, tipagem do HPV, imunidade para hepatite B e resultado da citologia oncótica tríplice das profissionais do sexo estudadas. Botucatu, 2009

\begin{tabular}{|c|c|c|}
\hline Variáveis & $N^{0}$ & $\%$ \\
\hline \multicolumn{3}{|l|}{ DST $(n=102)$} \\
\hline Sim & 73 & 71,6 \\
\hline Não & 29 & 28,4 \\
\hline \multicolumn{3}{|l|}{ Prevalência das DST $(n=102)$} \\
\hline Papiloma vírus humano (HPV) & 46 & 45,1 \\
\hline Chlamydia trachomatis (CT) & 3 & 2,9 \\
\hline Sífilis & 1 & 1,0 \\
\hline \multicolumn{3}{|l|}{ Infecções Mistas } \\
\hline $\mathrm{CT}+\mathrm{HPV}$ & 16 & 15,6 \\
\hline Trichomanas vaginalis (TV) + HPV & 2 & 2,0 \\
\hline Sífilis + HPV & 2 & 2,0 \\
\hline $\mathrm{TV}+\mathrm{CT}+\mathrm{HPV}$ & 1 & 1,0 \\
\hline Sífilis + HPV + CT & 1 & 1,0 \\
\hline HIV + HPV & 1 & 1,0 \\
\hline \multicolumn{3}{|l|}{ HPV (n=102) } \\
\hline Sim & 69 & 67,6 \\
\hline Não & 33 & 32,4 \\
\hline \multicolumn{3}{|l|}{ Genótipos do HPV (n=69) } \\
\hline 18 & 17 & 24,6 \\
\hline 33 & 6 & 8,7 \\
\hline 18 e 33 & 4 & 5,8 \\
\hline $6 / 11,18$ e 33 & 4 & 5,8 \\
\hline $6 / 11$ e 33 & 2 & 2,9 \\
\hline 16,18 e 33 & 1 & 1,4 \\
\hline 16 e 33 & 1 & 1,4 \\
\hline Outros* & 34 & 49,3 \\
\hline
\end{tabular}


Tabela 6. Ocorrência de DST, tipagem do HPV, imunidade para hepatite B e resultado da citologia oncótica tríplice das profissionais do sexo estudadas. Botucatu, 2009 - Continuação.

\begin{tabular}{|c|c|c|}
\hline Variáveis & $\mathbf{N}^{0}$ & $\%$ \\
\hline \multicolumn{3}{|l|}{ Vacinação para Hepatite B (n=102) } \\
\hline Sim & 48 & 47,0 \\
\hline Não & 54 & 53,0 \\
\hline \multicolumn{3}{|l|}{ Resultado da COT (n=102) } \\
\hline Negativo para neoplasia & 97 & 95,0 \\
\hline Lesão intraepitelial de baixo grau & 2 & 2,0 \\
\hline Lesão intraepitelial de alto grau & 1 & 1,0 \\
\hline $\begin{array}{l}\text { Células escamosas atípicas de significado indeterminado } \\
\text { (possivelmente não neoplásicas) }\end{array}$ & 1 & 1,0 \\
\hline $\begin{array}{l}\text { Células escamosas atípicas de significado indeterminado } \\
\text { (não se pode afastar lesão intraepitelial de alto grau) }\end{array}$ & 1 & 1,0 \\
\hline
\end{tabular}

À citopatologia, duas PS (2,0\%) apresentaram diagnóstico de lesão intraepitelial de baixo grau e apenas um diagnóstico de lesão intraepitelial de alto grau foi estabelecido. Ainda neste grupo de mulheres, dois casos de células atípicas de significado indeterminado foram diagnosticados, sendo um caso possivelmente não neoplásico e outro em que não foi possível afastar lesão de alto grau (Tabela 6).

Buscaram-se associações entre DST e idade, variáveis ginecológicas, comportamentais e achados clínicos (Tabelas 7 a 9). 
Tabela 7. Associação entre DST e idade/variáveis ginecológicas das profissionais do sexo estudadas $(n=102)$. Botucatu, 2009.

\begin{tabular}{|c|c|c|c|c|c|c|c|c|}
\hline \multicolumn{9}{|c|}{ DST } \\
\hline $\begin{array}{l}\text { Variáveis } \\
\text { Ginecológicas }\end{array}$ & Sim & $\%$ & Não & $\%$ & Total & $\%$ & $\begin{array}{c}\mathrm{p} \\
\text { valor }\end{array}$ & OR (IC 95\%) \\
\hline Idade & & & & & & & 0,3434 & $1,5(0,63-3,73)$ \\
\hline Até 26 anos & 50 & 74,6 & 17 & 25,4 & 67 & 100,0 & & \\
\hline Acima de 26 anos & 23 & 65,7 & 12 & 34,3 & 35 & 100,0 & & \\
\hline Coitarca até 15 a & & & & & & & 0,8779 & $1,8(0,44-2,56)$ \\
\hline Sim & 44 & 72,1 & 17 & 27,9 & 61 & 100,0 & & \\
\hline Não & 29 & 70,7 & 12 & 29,3 & 41 & 100,0 & & \\
\hline História de DST & & & & & & & 0,7770 & $1,2(0,40-3,32)$ \\
\hline Sim & 17 & 73,9 & 6 & 26,1 & 23 & 100,0 & & \\
\hline Não & 56 & 70,9 & 23 & 29,1 & 79 & 100,0 & & \\
\hline Sangramento* & & & & & & & 0,2642 & $2,4(0,49-11,54)$ \\
\hline Sim & 11 & 84,6 & 2 & 15,4 & 13 & 100,0 & & \\
\hline Não & 62 & 69,7 & 27 & 30,3 & 89 & 100,0 & & \\
\hline Corrimento & & & & & & & 0,7778 & $1,1(0,47-2,72)$ \\
\hline Sim & 45 & 72,6 & 17 & 27,4 & 62 & 100,0 & & \\
\hline Não & 28 & 70,0 & 12 & 30,0 & 40 & 100,0 & & \\
\hline Disúria & & & & & & & 0,9846 & $1,0(0,37-2,59)$ \\
\hline Sim & 20 & 71,4 & 8 & 28,6 & 28 & 100,0 & & \\
\hline Não & 53 & 71,6 & 21 & 28,4 & 74 & 100,0 & & \\
\hline Anticoncepcional & & & & & & & 0,5536 & $1,6(0,34-7,04)$ \\
\hline Sim & 68 & 72,3 & 26 & 27,7 & 94 & 100,0 & & \\
\hline Não & 5 & 62,5 & 3 & 37,5 & 8 & 100,0 & & \\
\hline COT & & & & & & & 0,6654 & $0,7(0,13-3,57)$ \\
\hline Sim & 66 & 71,0 & 27 & 29,0 & 93 & 100,0 & & \\
\hline Não & 7 & 77,8 & 2 & 22,2 & 9 & 100,0 & & \\
\hline
\end{tabular}

Não houve associação estatisticamente significativa entre DST, idade e variáveis ginecológicas das PS (Tabela 7). 
Tabela 8. Associação entre DST e achados clínicos das profissionais do sexo estudadas ( $n=102)$. Botucatu, 2009.

\begin{tabular}{lcccccccc}
\hline & & \multicolumn{7}{c}{ DST } \\
$\begin{array}{l}\text { Achados } \\
\text { clínicos }\end{array}$ & Sim & $\%$ & Não & $\%$ & Total & $\%$ & p valor & OR (IC 95\%) \\
\hline Colo friável & & & & & & & 0,9281 & $1,1(0,3-4,3)$ \\
Sim & 8 & 72,7 & 3 & 27,3 & 11 & 100,0 & & \\
Não & 65 & 71,4 & 26 & 28,6 & 91 & 100,0 & & \\
Ectopia & & & & & & & 0,0875 & $2,7(0,8-8,7)$ \\
Sim & 22 & 84,6 & 4 & 15,4 & 26 & 100,0 & & \\
Não & 51 & 67,1 & 25 & 32,9 & 76 & 100,0 & & \\
Conteúdo & & & & & & & 0,0836 & $2,1(0,9-5,1)$ \\
vaginal & & & & & & & & \\
Sim & 44 & 78,6 & 12 & 21,4 & 56 & 100,0 & & \\
Não & 29 & 63,0 & 17 & 37,0 & 46 & 100,0 & & \\
pH & & & & & & & 0,2339 & $1,7(0,7-4,3)$ \\
Sim & 54 & 75,0 & 18 & 25,0 & 72 & 100,0 & & \\
Não & 19 & 63,3 & 11 & 36,7 & 30 & 100,0 & & \\
Whiff test & & & & & & & 0,5034 & $0,7(0,3-1,8)$ \\
Sim & 40 & 69,0 & 18 & 31,0 & 58 & 100,0 & & \\
Não & 33 & 75,0 & 11 & 25,0 & 44 & 100,0 & & \\
\hline
\end{tabular}

Não houve associação estatisticamente significativa entre DST e achados clínicos das PS (Tabela 8). 
Tabela 9. Associação entre DST e variáveis comportamentais das PS estudadas $(n=102)$. Botucatu, 2009.

\begin{tabular}{|c|c|c|c|c|c|c|c|c|}
\hline \multicolumn{9}{|c|}{ DST } \\
\hline $\begin{array}{l}\text { Variáveis } \\
\text { comportamentais }\end{array}$ & Sim & $\%$ & Não & $\%$ & Total & $\%$ & $\begin{array}{c}\mathrm{p} \\
\text { valor }\end{array}$ & OR (IC 95\%) \\
\hline Sexo oral & & & & & & & 0,9078 & $1,0(0,26-4,53)$ \\
\hline Sim & 66 & 71,7 & 26 & 28,3 & 92 & 100,0 & & \\
\hline Não & 7 & 70,0 & 3 & 30,0 & 10 & 100,0 & & \\
\hline Sexo anal & & & & & & & 0,4127 & $1,5(0,58-3,65)$ \\
\hline Sim & 29 & 76,3 & 9 & 23,7 & 38 & 100,0 & & \\
\hline Não & 44 & 68,8 & 20 & 31,3 & 64 & 100,0 & & \\
\hline Ducha vaginal & & & & & & & 0,2041 & $1,8(0,73-4,27)$ \\
\hline Sim & 50 & 75,8 & 16 & 24,2 & 66 & 100,0 & & \\
\hline Não & 23 & 63,9 & 13 & 36,1 & 36 & 100,0 & & \\
\hline Tampão vaginal & & & & & & & 0,2724 & $0,6(0,25-1,46)$ \\
\hline Sim & 34 & 66,7 & 17 & 33,3 & 51 & 100,0 & & \\
\hline Não & 39 & 76,5 & 12 & 32,5 & 51 & 100,0 & & \\
\hline Tabagismo & & & & & & & 0,6696 & $1,2(0,48-3,04)$ \\
\hline Sim & 51 & 72,9 & 19 & 27,1 & 70 & 100,0 & & \\
\hline Não & 22 & 68,8 & 10 & 31,3 & 32 & 100,0 & & \\
\hline Uso de álcool & & & & & & & 0,7854 & $1,8(0,36-3,73)$ \\
\hline Sim & 62 & 72,1 & 24 & 27,9 & 86 & 100,0 & & \\
\hline Não & 11 & 68,8 & 5 & 31,3 & 16 & 100,0 & & \\
\hline $\begin{array}{l}\text { História de uso de } \\
\text { drogas }\end{array}$ & & & & & & & 0,2374 & $1,7(0,70-4,03)$ \\
\hline Sim & 47 & 75,8 & 15 & 24,2 & 62 & 100,0 & & \\
\hline Não & 26 & 65,0 & 14 & 35,0 & 40 & 100,0 & & \\
\hline Uso de drogas & & & & & & & 0,9201 & $1,0(0,43-2,50)$ \\
\hline Sim & 31 & 72,1 & 12 & 27,9 & 43 & 100,0 & & \\
\hline Não & 42 & 71,2 & 17 & 28,8 & 59 & 100,0 & & \\
\hline Parceiro fixo & & & & & & & 0,6908 & $1,2(0,44-3,42)$ \\
\hline Sim & 58 & 72,5 & 22 & 27,5 & 80 & 100,0 & & \\
\hline Não & 15 & 68,2 & 7 & 31,8 & 22 & 100,0 & & \\
\hline
\end{tabular}

Não houve associação estatisticamente significativa entre DST e variáveis comportamentais das PS (Tabela 9). 
Considerando-se a elevada prevalência do HPV, buscaram-se suas associações com a idade da PS, variáveis ginecológicas, comportamentais e achados clínicos (Tabelas 10 a 12).

Tabela 10. Associação entre HPV e idade e variáveis ginecológicas das PS estudadas $(n=102)$. Botucatu, 2009

\begin{tabular}{|c|c|c|c|c|c|c|c|c|}
\hline \multicolumn{9}{|c|}{ HPV } \\
\hline $\begin{array}{l}\text { Variáveis } \\
\text { Ginecológicas }\end{array}$ & Sim & $\%$ & Não & $\%$ & Total & $\%$ & $\begin{array}{c}\mathrm{p} \\
\text { valor }\end{array}$ & OR (IC 95\%) \\
\hline Idade & & & & & & & 0,2327 & $1,7(0,71-3,98)$ \\
\hline Até 26 anos & 48 & 71,6 & 19 & 28,4 & 67 & 100,0 & & \\
\hline Acima de 26 anos & 21 & 60,0 & 14 & 40,0 & 35 & 100,0 & & \\
\hline Coitarca até 15 a & & & & & & & 0,7509 & $1,1(0,49-2,66)$ \\
\hline Sim & 42 & 68,9 & 19 & 31,1 & 61 & 100,0 & & \\
\hline Não & 27 & 65,9 & 14 & 34,1 & 41 & 100,0 & & \\
\hline História de DST & & & & & & & 0,3231 & $1,1(0,41-3,06)$ \\
\hline Sim & 16 & 69,6 & 7 & 30,4 & 23 & 100,0 & & \\
\hline Não & 53 & 67,1 & 26 & 32,9 & 79 & 100,0 & & \\
\hline Sangramento* & & & & & & & 0,1615 & $2,9(0,61-14,10)$ \\
\hline Sim & 11 & 84,6 & 2 & 15,4 & 13 & 100,0 & & \\
\hline Não & 58 & 65,2 & 31 & 34,8 & 89 & 100,0 & & \\
\hline Corrimento & & & & & & & 0,9769 & $1,0(0,43-2,36)$ \\
\hline Sim & 42 & 67,7 & 20 & 32,3 & 62 & 100,0 & & \\
\hline Não & 27 & 67,5 & 13 & 32,5 & 40 & 100,0 & & \\
\hline Disúria & & & & & & & 0,6553 & $0,8(0,32-2,02)$ \\
\hline Sim & 18 & 64,3 & 10 & 35,7 & 28 & 100,0 & & \\
\hline Não & 51 & 68,9 & 23 & 31,1 & 74 & 100,0 & & \\
\hline Anticoncepcional & & & & & & & 0,7458 & $1,3(0,28-5,71)$ \\
\hline Sim & 64 & 68,1 & 30 & 31,9 & 94 & 100,0 & & \\
\hline Não & 5 & 62,5 & 3 & 37,5 & 8 & 100,0 & & \\
\hline COT & & & & & & & 0,4962 & $0,6(0,11-2,91)$ \\
\hline Sim & 62 & 66,7 & 31 & 33,3 & 93 & 100,0 & & \\
\hline Não & 7 & 77,8 & 2 & 22,2 & 9 & 100,0 & & \\
\hline
\end{tabular}

*Após relação sexual.

Não houve associação estatisticamente significativa entre HPV, idade e variáveis ginecológicas das PS (Tabela 10). 
Tabela 11. Associação entre HPV e achados clínicos das profissionais do sexo estudadas $(n=102)$. Botucatu, 2009.

\begin{tabular}{|c|c|c|c|c|c|c|c|c|}
\hline \multicolumn{9}{|c|}{ HPV } \\
\hline $\begin{array}{l}\text { Achados } \\
\text { clínicos }\end{array}$ & Sim & $\%$ & Não & $\%$ & Total & $\%$ & $\begin{array}{c}\mathrm{p} \\
\text { valor }\end{array}$ & OR (IC 95\%) \\
\hline Colo friável & & & & & & & 0,7633 & $0,8(0,22-3,01)$ \\
\hline Sim & 7 & 63,6 & 4 & 36,4 & 11 & 100,0 & & \\
\hline Não & 62 & 68,1 & 29 & 31,9 & 91 & 100,0 & & \\
\hline Ectopia & & & & & & & 0,4929 & $1,4(0,52-3,78)$ \\
\hline Sim & 19 & 73,1 & 7 & 26,9 & 26 & 100,0 & & \\
\hline Não & 50 & 65,8 & 26 & 34,2 & 76 & 100,0 & & \\
\hline $\begin{array}{l}\text { Conteúdo } \\
\text { vaginal }\end{array}$ & & & & & & & 0,1848 & $1,7(0,76-4,05)$ \\
\hline Sim & 41 & 73,2 & 15 & 26,8 & 56 & 100,0 & & \\
\hline Não & 28 & 60,9 & 18 & 39,1 & 46 & 100,0 & & \\
\hline pH & & & & & & & 0,2856 & $1,6(0,66-3,94)$ \\
\hline Sim & 51 & 70,8 & 21 & 29,2 & 72 & 100,0 & & \\
\hline Não & 18 & 60,0 & 12 & 40,0 & 30 & 100,0 & & \\
\hline \multicolumn{9}{|l|}{ Whiff test } \\
\hline Sim & 38 & 65,5 & 20 & 34,5 & 58 & 100,0 & 0,5975 & $0,8(0,34-1,85)$ \\
\hline Não & 31 & 70,5 & 13 & 29,5 & 44 & 100,0 & & \\
\hline
\end{tabular}

Não houve associação estatisticamente significativa entre HPV e achados clínicos das PS (Tabela 11). 
Tabela 12. Associação entre HPV e variáveis comportamentais das profissionais do sexo estudadas $(n=102)$. Botucatu, 2009.

\begin{tabular}{|c|c|c|c|c|c|c|c|c|}
\hline \multicolumn{9}{|c|}{ HPV } \\
\hline $\begin{array}{l}\text { Variáveis } \\
\text { comportamentais }\end{array}$ & Sim & $\%$ & Não & $\%$ & Total & $\%$ & $\begin{array}{c}\mathrm{p} \\
\text { valor }\end{array}$ & OR (IC 95\%) \\
\hline Sexo oral & & & & & & & 0,8670 & $0,9(0,21-3,66)$ \\
\hline Sim & 62 & 67,4 & 30 & 32,6 & 92 & 100,0 & & \\
\hline Não & 7 & 70,0 & 3 & 30,0 & 10 & 100,0 & & \\
\hline Sexo anal & & & & & & & 0,5710 & $1,3(0,53-3,07)$ \\
\hline Sim & 27 & 71,1 & 11 & 28,9 & 38 & 100,0 & & \\
\hline Não & 42 & 65,6 & 22 & 34,4 & 64 & 100,0 & & \\
\hline Ducha vaginal & & & & & & & 0,5490 & $1,3(0,55-3,06)$ \\
\hline Sim & 46 & 69,7 & 20 & 30,3 & 66 & 100,0 & & \\
\hline Não & 23 & 63,9 & 13 & 36,1 & 36 & 100,0 & & \\
\hline Tampão vaginal & & & & & & & 0,1384 & $0,5(0,22-1,23)$ \\
\hline Sim & 31 & 60,8 & 20 & 39,2 & 51 & 100,0 & & \\
\hline Não & 38 & 74,5 & 13 & 25,5 & 51 & 100,0 & & \\
\hline Tabagismo & & & & & & & 0,7678 & $1,1(0,47-2,77)$ \\
\hline Sim & 48 & 68,6 & 22 & 31,4 & 70 & 100,0 & & \\
\hline Não & 21 & 65,6 & 11 & 34,4 & 32 & 100,0 & & \\
\hline Uso de álcool & & & & & & & 0,9181 & $0,9(0,29-2,97)$ \\
\hline Sim & 58 & 67,4 & 28 & 32,6 & 86 & 100,0 & & \\
\hline Não & 11 & 68,8 & 5 & 31,3 & 16 & 100,0 & & \\
\hline $\begin{array}{l}\text { História de uso de } \\
\text { drogas }\end{array}$ & & & & & & & 0,6462 & $1,2(0,52-2,83)$ \\
\hline Sim & 43 & 69,4 & 19 & 30,6 & 62 & 100,0 & & \\
\hline Não & 26 & 65,0 & 14 & 35,0 & 40 & 100,0 & & \\
\hline Uso de drogas & & & & & & & 0,6959 & $1,2(0,50-2,75)$ \\
\hline Sim & 30 & 69,8 & 13 & 30,2 & 43 & 100,0 & & \\
\hline Não & 39 & 66,1 & 20 & 33,9 & 59 & 100,0 & & \\
\hline Parceiro fixo & & & & & & & 0,6497 & $1,2(0,46-3,37)$ \\
\hline Sim & 55 & 68,8 & 25 & 31,3 & 80 & 100,0 & & \\
\hline Não & 14 & 63,6 & 8 & 36,4 & 22 & 100,0 & & \\
\hline
\end{tabular}

Não houve associação estatisticamente significativa entre HPV e variáveis comportamentais das PS (Tabela 12). 
5. DISCUSSÃO 
Este estudo apresenta dados locais detalhados sobre a população de mulheres profissionais do sexo de município de médio porte do interior paulista, especialmente quanto a aspectos sociodemográficos, antecedentes ginecológicos, obstétricos, sexuais e comportamentos de proteção e risco às DST, podendo constituir-se em referência para outros municípios e contribuir com a política de prevenção das DST no Estado de São Paulo. Porém, por tratar-se de estudo transversal, estando ausente o grupo de comparação, apenas algumas hipóteses podem ser levantadas para explicar a situação encontrada.

Muitas são as dificuldades enfrentadas pelos serviços de saúde para abordar as PS, pelo fato de viverem em estado de semiclandestinidade. Uma das maneiras de se atenuar esse problema é incorporando à pesquisa pessoas que tenham estabelecido vínculo de confiança com as potenciais participantes (PASSOS e FIGUEIREDO, 2004). Na presente investigação, isso foi viabilizado, já que todos os contatos necessários para organização da coleta de dados e a entrevista com as PS foram realizados com o apoio dos agentes de prevenção do Programa Municipal DST/aids, os quais possuem estreito vínculo com as PS e a pequena recusa em participar do estudo reflete isso.

A prostituição é uma profissão que lida diretamente com a sexualidade e, como em geral mulheres jovens despertam o interesse da população masculina, não é difícil encontrá-las trabalhando como $P S$, inclusive adolescentes (AQUINO et al., 2008). Neste estudo, a média de idade obtida (26,1 anos) é semelhante à encontrada em outras investigações desenvolvidas no Brasil (PIRES e MIRANDA, 1998; BENZAKEN et al., 2002; BENZAKEN et al., 2003; SILVA et al., 2007; CORREA et al., 2008) e no exterior (VAN DE HOEK et al.,1989; GOSSOP et al.,1995; ESTÉBANEZ et al.,1998) e diferente de estudos realizados na China, onde as médias de idade obtidas foram inferiores: 21,5 anos (LU et. al., 2009) e 23 anos (DING et al., 2009) e em Madagascar, 22 anos (HARIJAONA et al., 2009). Outros estudos relatam média de idade superior, em torno de 29 anos, no Senegal (LAURENT et al., 2003) e na Espanha (FOLCH et al., 2009). 
Com relação à escolaridade, a situação encontrada, em que 53,0\% das participantes do estudo apresentavam nove anos ou mais de aprovação escolar, é mais favorável que a encontrada em outras investigações brasileiras: em Ribeirão Preto/SP, $70,0 \%$ da população estudada tinha no máximo 8 anos de aprovação escolar (PASSOS e FIGUEIREDO, 2004). Na Cataluña, Espanha, 55,8\% das PS tinham educação primária (FOLCH et al., 2009), o mesmo sendo encontrado em Madagascar, África. Na China, a média de escolaridade foi de 7,3 anos, sendo que $64,4 \%$ das PS tinham ensino médio ou superior (DING et al., 2005). Em estudo realizado com PS no interior do Amazonas, Brasil, a média de anos de estudo foi de até 8 anos (BENZAKEN et al., 2003), enquanto no Senegal (LAURENT et al., 2003) e na Guatemala a maioria das PS eram analfabetas (SABIDÓ et al., 2009).

Em um Centro de Referência em DST/AIDS, 63,3\% das mulheres haviam completado o ensino fundamental (PIRES e MIRANDA, 1998), e em Umuarama/PR metade das participantes não havia completado o ensino fundamental (CORREA et al., 2008). Porém, situação obtida na presente investigação é semelhante à escolaridade das mulheres brasileiras, já que $50,5 \%$ da população feminina no país têm mais de 8 anos de aprovação escolar (IBGE, 2008).

Mais da metade das participantes $(59,8 \%)$ referiu ter iniciado vida sexual antes dos 15 anos de idade, mais precoce do que a idade encontrada em estudo desenvolvido em 2007, em que as primeiras relações sexuais haviam ocorrido entre 15 e 16 anos (SILVA et al., 2007). Estudo chinês evidenciou coitarca entre 15 e 19 anos para 61,4\% das PS (DING et al., 2005) e na Índia, $43,5 \%$ das mulheres referiram coitarca entre 16 e 20 anos (THAKOR et al., 2004). Revela-se aqui a percepção dos jovens sobre as fases da vida, sendo a juventude encarada como período de liberdade, propício para experimentação do prazer (AQUINO et al., 2008). A relevância do início precoce da atividade sexual em relação às DST/aids ainda é controversa, podendo ser apontada como fator de propagação e vulnerabilidade (BRASIL, 2006b; AQUINO et al., 2008) ou não (CORREA et al., 2008). 
A maioria das participantes desta investigação era solteira, o que está de acordo com outros estudos nacionais e internacionais (PIRES e MIRANDA, 1998; CORREA et al., 2008; AQUINO et al., 2008, LU et al., 2009; DING et al., 2005; HARIJAONA et al., 2009; SABIDÓ et al., 2009). Estudo realizado em Dakar, Senegal, encontrou a maioria das PS divorciadas (LAURENT et al., 2003).

Eram nulíparas 26,5\% das PS estudadas, número bastante inferior aos 55,0\% encontrado em PS de Umuarama, Paraná (CORREA et al., 2008); em Madagascar, identificaram-se 66\% de primíparas (HARIJAONA et al., 2009) e na Guatemala 83,3\% das mulheres tinham pelo menos um filho (SABIDÓ et al., 2009). Em relação ao número de abortos, $23,5 \%$ das PS desse estudo tiveram um episódio, valor semelhante ao encontrado em província do sudoeste da Guatemala: 23,4\% (SABIDÓ et al., 2009).

Entre as PS estudadas, 22,5\% tinham história de DST prévia, valor muito inferior ao encontrado na China (DING et al., 2005) e Guatemala (SABIDÓ et al., 2009), onde $49 \%$ e $52,1 \%$ das mulheres tiveram este relato, respectivamente. $\mathrm{Na}$ presente investigação, entre as DST mais citadas estavam: condiloma acuminado (37,5\%) e herpes genital $(16,7 \%)$, enquanto em estudo chinês, $10,8 \%$ das PS referiram verruga genital e $11,1 \%$ delas úlcera genital. (DING et al., 2005). A queixa de corrimento vaginal entre as participantes deste estudo, $60,8 \%$, foi superior aos $44,5 \%$ encontrados na Guatemala (SABIDÓ et al., 2009) e 46,2\% na China (DING et al., 2005).

Em estudo desenvolvido em município de grande porte do interior paulista, $48 \%$ das PS referiram número médio diário de parceiros igual ou superior a três (Passos \& Figueiredo, 2004) e em Manacapuru (AM), a média de clientes/dia referidos variou de um a três (BENZAKEN et al., 2003). No Senegal (LAURENT et al., 2003) e na China (LU et al., 2009; WANG et al., 2009), a média de clientes referidos foi mais baixa, variando de zero a três por semana, e de 2,8 a três clientes/semana, respectivamente. Nesta investigação, $72,5 \%$ das participantes apontaram até cinco parceiros por semana, enquanto 
em Madagascar $74 \%$ das PS referiram mais de 5 parceiros/dia (HARIJAONA et al., 2009).

A relevância em se conhecer o número de parceiros decorre do fato de sua possível associação às DST. Para o Ministério da Saúde do Brasil, ter mais de um parceiro sexual em três meses é fator de risco para aquisição de DST (BRASIL, 2006a).

Vários estudos têm mostrado que a ducha vaginal (água, água misturada com sal ou produtos comerciais, entre outros) é prática comum entre mulheres em todo o mundo (REED et al., 2001; FONCK et al., 2001). Há algumas evidências de que a ducha vaginal frequente pode aumentar a susceptibilidade de uma mulher a agentes sexualmente transmissíveis através da modificação da flora vaginal. Uma meta-análise revisando 13 estudos revelou que duchas frequentes pareciam estar altamente associadas à doença inflamatória pélvica (DIP) e modestamente associada à gravidez ectópica e câncer cervical (ZHANG et al., 1997).

A realização frequente de ducha vaginal também tem sido apontada como capaz de aumentar o risco de uma mulher contrair HIV. No entanto, dados sobre a prevalência desta prática e sua associação com o uso do preservativo e DST são limitados (WANG, et al., 2005). O presente estudo indica que o uso de ducha vaginal é prática comum das PS de Botucatu, visto que $64,7 \%$ delas referiram usá-la, prevalência semelhante à encontrada entre PS chinesas (WANG, et al., 2005), que referiram fazer uso por acreditarem em sua capacidade de prevenir DST/HIV/aids, expondo-as a risco ainda maior de contraírem DST. Deve-se destacar que o citado estudo chinês encontrou associação do uso de ducha vaginal com: diminuição do uso de preservativo e aumento de antecedentes de DST.

Ducha vaginal foi fator de risco para HIV entre as mulheres que trabalhavam nas ruas da China. Entre as PS portadoras do HIV, a maioria relatou fazer ducha vaginal com sabão, água e espermicida, havendo diferença significativa entre infecção por HIV, ducha e o tipo de produto utilizado (WANG et al., 2009). Em Botucatu, São Paulo, 64,7\% das PS relataram fazer uso de 
ducha, enquanto na China, $84,1 \%$ das mulheres PS usavam esse procedimento, apontando os autores a crescente substituição do uso do preservativo por esta prática (WANG et al., 2009)

Em relação à prática sexual, sexo oral $(90,2 \%)$ foi muito mais frequentemente referido que o anal $(37,3 \%)$, mesmo achado de pesquisa nacional onde essas práticas foram respectivamente citadas por $82,4 \%$ e 39,8\% das PS (GUIMARÃES e MERCHÁN-HAMANN, 2005). Neste último estudo, a região sudeste foi apontada como aquela em que o sexo oral é mais habitualmente desenvolvido (apenas $10,9 \%$ das prostitutas nunca o aceitam) e a região norte destacou-se com relação ao sexo anal (metade das PS não o negam). Na Espanha, estudo apontou que 10,3\% das PS faziam sexo anal (FOLCH et al., 2009). Destaca-se que no sexo anal há um elevado risco de transmissão de DST/HIV, devido à intensa vascularização local, passível de maiores microtraumatismos durante a penetração (NAUD et al., 2006). A taxa de infectividade pelo HIV durante o coito anal é de 0,1 a 0,3\% em mulheres (FREITAS, 2006).

Apesar de 99,0\% das mulheres terem afirmado usar preservativo com os clientes, muitas deixam de fazê-lo com parceiro fixo, o que as expõem à situação de maior vulnerabilidade: 80 PS participantes do estudo $(78,4 \%)$ relataram ter parceiro fixo e apenas $26,3 \%$ usavam preservativo nas relações sexuais com eles. No estudo de Ribeirão Preto, já citado, apesar da menor frequência de parceiro fixo, $28,4 \%$ das PS relataram tê-lo e não usar preservativo neste tipo de relação (PASSOS e FIGUEIREDO, 2004). Outros estudos chineses também apontam a pequena frequência de uso de preservativo com parceiros fixos: no sul da China, $71,2 \%$ das mulheres faziam uso inconsistente de preservativo nestas relações (LU et al., 2009) e em Kaiyuan City 84\% delas não usavam preservativo com parceiro fixo (WANG et al., 2009). Situação mais favorável foi obtida em Fortaleza, CE já que 56,2\% das PS que tinham parceiro fixo usavam preservativo com eles (AQUINO et al., 2008). Esses dados confirmam a afirmação de que o principal fator preditivo para o não uso de preservativo é a existência de um parceiro fixo (JIMÉNEZ et al., 2001), o que pode decorrer da confiança e do sentimento de que o uso do 
preservativo caracterizaria a relação sexual como comercial, fato indesejado quando se trata de parceiro com quem se mantém algum vínculo afetivo (PASSOS e FIGUEIREDO, 2004).

A importância do uso do preservativo é apontada por estudos chineses: mulheres PS que relataram não usar preservativo pelo menos duas vezes ao mês foram mais susceptíveis às DST, já que $64,1 \%$ delas apresentaram pelo menos um episódio, enquanto entre aquelas que relataram uso consistente ou raras relações sexuais sem ele, 30,0\% tiveram DST (DING et al., 2005). No mesmo país, estudo com 737 PS evidenciou redução de $70 \%$ na infecção pelo vírus HIV nas mulheres que faziam uso consistente do preservativo com clientes (WANG et al., 2009).

Merece ser destacado, ainda, que o valor obtido para o uso de preservativo no trabalho $(99,0 \%)$ é bastante superior ao de outros estudos com PS: $61,3 \%$ (CORREA et al., 2008), 42,7\% (CAMEJO et al., 2003) e 62,5\% (LU et al., 2009), assim como na população geral: $63 \%$ (PAIVA et al., 2002). Isso evidencia que as mulheres estudadas adotam medidas preventivas rotineiramente, mas apenas em seu trabalho, reforçando a afirmação de que, de modo geral, os comportamentos de prevenção às DST/aids pelas PS são mais frequentes nas relações sem envolvimento, ou seja, nos programas (OLTRAMARI e CAMARGO, 2004). A situação de Botucatu é melhor que a descrita em estudo realizado na China, onde $15 \%$ das mulheres relataram uso consistente do preservativo com seus clientes e $8,4 \%$, com os seus parceiros regulares (WANG, et al., 2005). Outro estudo, realizado com 196 mulheres PS, $23 \%$ relataram usar sempre preservativo e $58 \%$ delas com muita frequência (JIMÉNEZ DÍAZ et al., 2001). Na Indonésia, 69,9\% das PS referiram adotar o sexo seguro (FORD et al., 2000). Na Espanha, 95,5\% e $87,2 \%$ das PS referiram uso de preservativo com clientes no sexo vaginal e anal, respectivamente. Com parceiro estável, as prevalências foram muito inferiores: $12,4 \%$ e $17,4 \%$ para sexo vaginal e anal, respectivamente (FOLCH et al. 2009).

Ainda sobre o uso do preservativo, estudo realizado na Indonésia (BASUKIE et al., 2002) encontrou entre as principais razões para o não uso por 
PS o desconhecimento de seu papel protetor e a crença na redução do prazer. Por outro lado, intervenção realizada em Malawi, África, a partir de ações educativas, conseguiu incrementar o uso do insumo com clientes em 90,3\%, porém fracassou ao tentá-lo com o parceiro fixo (WALDEN et al., 1999).

No Japão, foram investigadas as tendências das DST, considerando-se os padrões de uso de preservativo entre mulheres PS. Coerentemente, evidenciou-se redução na prevalência das DST à medida que ocorreu aumento na frequência do uso do preservativo (TANAKA et al., 1998). Destaca-se estudo Chinês, onde as PS infectadas pelo vírus HIV não usavam o preservativo de forma consistente nem com clientes, nem com seus parceiros sexuais regulares, colocando ambos em risco de infecção (WANG et al., 2009). As razões para a não utilização do preservativo com clientes, nesse país, foram porque conheciam o cliente $(49,2 \%)$, gostavam do cliente $(48,6 \%)$, pela compensação financeira $(18,0 \%)$ ou para atender ao pedido destes, razão citada por $17,8 \%$ das mulheres (DING et al., 2005).

De modo geral, a confiança no parceiro está ligada ao grau de envolvimento no ato sexual e, por este motivo, com parceiro fixo, pode haver a sensação de um encontro sexual seguro, no qual a falta de confiança representada pelo uso do preservativo - abalaria a relação (AQUINO et al., 2008). Porém, sabe-se que ações preventivas não devem estar vinculadas à fidelidade, nem se deve associar a existência do parceiro fixo com relacionamento seguro.

No México, após a realização de intervenções focadas na identificação das motivações para praticar sexo seguro ou sexo de risco; identificação das barreiras e motivações para uso do preservativo, negociação de sexo seguro com clientes e suporte social, houve aumento significativo no uso do preservativo, sendo que as mulheres que melhoraram o conhecimento sobre HIV/aids aumentaram o uso deste com seus clientes (STRATHDEE et al., 2009).

Na Guatemala, o rastreio e tratamento regulares das DST/HIV/aids, combinado com a promoção do uso do preservativo e a prevenção de 
comportamentos de risco foi eficaz na redução do HIV e DST entre as PS que receberam intervenção voltada à prevenção, diagnóstico e tratamento. O uso de preservativo com clientes aumentou de $94,2 \%$ para $99,1 \%$ e com parceiro fixo, de 90,3\% para 97,2\% (SABIDÓ et al., 2009).

A elevada prevalência de uso de método contraceptivo deste estudo $(92,2 \%)$ foi semelhante à encontrada no norte do país em 2001 : $97,1 \%$ (BENZAKEN et al., 2003). Já a prevalência obtida para história pessoal de DST entre as mulheres estudadas $(22,5 \%)$ foi intermediária à encontrada em outras investigações nacionais: 50\% (PIRES e MIRANDA, 1998) e 16\% (AQUINO et al., 2008), sendo o condiloma acuminado a mais frequente DST citada (37,5\%), diferente da situação encontrada em Fortaleza, CE onde a gonorreia ou "esquentamento" foi citada por $61,5 \%$ das mulheres (AQUINO et al., 2008).

O consumo abusivo de álcool e drogas ilícitas constitui um dos principais problemas de saúde pública nas sociedades contemporâneas (REHM et al., 2006). Diversos estudos documentam a associação entre o consumo de álcool e drogas, como cocaína/crack e o uso inconsistente de preservativos (BASTOS et al., 2008 b). Na presente investigação, o uso de álcool no trabalho (sim, não) foi elevado, sendo referido por 86 mulheres $(84,3 \%)$. Porém, o fato de não ter sido melhor investigada a frequência e o número de doses ingeridas dificulta a comparação com outros estudos nacionais e internacionais. Em município do interior de São Paulo, 62,1\% das PS referiam ingerir bebida alcoólica diariamente ou pelo menos uma vez na semana (PASSOS e FIGUEIREDO, 2004) e, em recente estudo de Umuarama/PR, os índices de consumo foram ainda maiores, 94,7\% (CORREA et al., 2008). Na Espanha, o número médio de copos de bebida alcoólica por semana foi 3,5 (FOLCH et al., 2009).

Esses achados devem ser decorrentes do grande número de prostitutas que trabalham em boates e bares, pois se sabe que entre suas funções, impostas pelo dono do estabelecimento, está a indução dos clientes ao consumo de bebidas alcoólicas, fato que resulta em maior lucro. Também se aponta, como justificativa para o elevado consumo, o papel facilitador do álcool, tendo em vista seu efeito redutor de inibição, resultando no enfrentamento das 
dificuldades mais facilmente (PASSOS e FIGUEIREDO, 2004).

Em termos do impacto sobre a saúde pública e dos danos e riscos associados ao consumo de álcool e drogas, é mais realista e proveitoso pensar no abuso dessas substâncias de forma integrada, enquanto substâncias com ação sobre o psiquismo e o comportamento (Bastos et al., 2008b).

Além do álcool, outras drogas fazem parte do cotidiano das mulheres incluídas neste estudo. Tabagismo foi referido por 68,6\% delas, valor próximo ao obtido no Paraná: 64\% (CORREA et al., 2008); o uso de drogas ilícitas também foi frequente nesta população: $60,8 \%$ das PS referiram ter feito uso em algum momento de sua vida, sendo o uso associado citado por 53,2\% delas. Isoladamente, a maconha e a cocaína foram as mais citadas, ambas $22,6 \%$.

Houve referência ao uso drogas na atualidade por $42,2 \%$ das PS, frequentemente $(41,9 \%)$ de forma associada (maconha, cocaína e crack), seguida do uso isolado da cocaína $(30,2 \%)$, valores muito superiores aos obtidos na Guatemala, onde a prevalência do uso de cocaína foi 4,4\% e de crack 1,7\% (SABIDÓ et al., 2009). Estudo semelhante (CORREA et al., 2008), obteve que $50 \%$ da população estudada fazia uso de drogas, lícitas ou ilícitas, sendo comum a associação de drogas ilícitas ao tabaco (36\%), especialmente tabaco-cocaína-maconha (16\%). Destaca-se que alguns estudiosos têm discutido que para as PS o controle no uso de álcool e de outras substâncias psicoativas é aspecto fundamental para seu desempenho no trabalho (SIMON et al., 2002).

Na Espanha, investigou-se o uso de drogas por $400 \mathrm{PS}$, sendo que $24,5 \%$ referiram uso de droga nos últimos 6 meses e 1,3\% uso de droga injetável alguma vez na vida (FOLCH et al., 2009). Estudo realizado na Guatemala não encontrou nenhum relato de uso de droga injetável (SABIDÓ et al., 2009).

Na China, boa parte dos casos estimados de HIV (44,3\%) se dá entre os usuários de drogas injetáveis (MINISTRY OF HEALTH, PEOPLE'S REPUBLIC OF CHINA, UNAIDS, and WHO, 2006). Por outro lado, o uso de drogas injetáveis entre prostitutas é elevado em alguns países (ESTÉBANEZ et al., 
2000; TYNDALL et al., 2002; LAU et al., 2005; BREEN et al., 2005), mas em outros não (VERSTER et al., 2001; DING et al., 2005). Em Kaiuyan City, China, entre as PS usuárias de drogas injetáveis, 49,3\% eram portadoras do HIV, enquanto entre as não usuárias, a prevalência foi 19,6\%, de onde se conclui que o uso de drogas ilegais, especialmente o uso de drogas injetáveis, é fator de risco para a aquisição do HIV (WANG et al., 2009). No sul do país, também se encontraram maiores taxas de HIV entre as usuárias de drogas injetáveis (FOLCH et al., 2009)

Em Hanói, no Vietnã, estudo realizado com 37 profissionais do sexo buscou examinar as causas do aumento de infecção pelo HIV, aparecendo o uso de drogas injetáveis com muita frequência. As PS usuárias de drogas injetáveis foram apontadas como pertencentes ao grupo com maior comportamento de risco para a infecção pelo HIV podendo, potencialmente, servir como ponte através dos seus principais clientes para a população em geral (TRAN et al., 2004).

Em Yunnan, China, a infecção pelo HIV foi associada ao início precoce do uso de drogas injetáveis, antes dos 20 anos de idade. Apesar do conhecimento sobre a transmissão do HIV, a partilha de agulhas e o sexo desprotegido persistem nesta população, que possui elevada prevalência do HIV (YAO et al., 2009). Outro estudo chinês revelou que comportamentos sexuais de risco, como o não uso de preservativos com clientes, foram mais frequentemente encontrados em PS usuárias de drogas injetáveis do que entre PS não usuárias dessas drogas, mas não foram encontradas diferenças entre esses dois grupos quando se considerou o uso de preservativo com parceiros fixos (LAU et al., 2007).

Ressalta-se, ainda, que o uso de crack tem grande relevância para a transmissão das DST, inquestionavelmente, pelo fato de sua grande capacidade de produzir dependência. Do ponto de vista econômico, essa dependência torna a sua demanda inelástica em relação ao preço e à renda do usuário, diferentemente do tabaco e da maconha, cuja elasticidade de demanda se reflete na redução do consumo como resposta a esses fatores. 
Estas condições tornam as PS mais vulneráveis, muitas vezes aumentando o número e reduzindo o preço do programa (PASSOS e FIGUEIREDO, 2004).

Apesar da relevância da abordagem do uso de drogas lícitas ou ilícitas com as PS, a forma como os dados foram obtidos nesta investigação evidencia fragilidade para esse tipo de discussão, pois, além da inexistência de informação sobre o número de doses consumidas, anteriormente apontado, também não se investigou a via de administração, quando do uso de drogas ilícitas, questões que merecem ser mais bem abordadas com esse grupo de mulheres em estudos futuros.

Especificamente com relação ao resultado da citologia oncótica das PS, $5 \%$ delas apresentaram alterações importantes, como lesão de baixo grau e até lesões onde não se pôde afastar lesão de alto grau, aproximadamente metade do valor obtido em estudo de Vitória, ES, em que 9,4\% das PS se enquadravam na classe III do exame de Papanicolaou (PIRES e MIRANDA, 1998).

No momento do exame especular, $55 \%$ das participantes apresentavam conteúdo vaginal, valor inferior ao encontrado em 2002 em município do interior do norte do país: 98\% (BENZAKEN et al., 2002).

No presente estudo, a prevalência geral de DST obtida entre as PS estudadas foi elevada: $71,6 \%$, devendo ser destacada a ocorrência isolada ou em associação do HPV $(45,1 \%$ e $22,6 \%$, respectivamente) e de C. trachomatis (2,9\% e 17,6\%, respectivamente). Também merece destaque a prevalência geral, incluindo associações, de sífilis $(4,0 \%)$ e tricomoníase $(3,0 \%)$, a ocorrência de um caso de HIV (1,0\%) e a inexistência de gonorreia e Hepatite B na população estudada.

A comparação desses dados com os obtidos em outros estudos nacionais não é simples, devido à diversidade de exames diagnósticos existentes e ao fato de que muitos destes estudos não contemplam as mesmas DST incluídas na presente investigação, que se utilizou apenas de exames considerados padrão-ouro de diagnóstico. Para viabilizar a discussão, os dados obtidos serão comparados considerando-se a população feminina em geral e 
de PS ou outros grupos vulneráveis em particular, com outros estudos que também se utilizaram de exames padrão-ouro.

A prevalência de HPV $(67,7 \%)$ foi muito superior à encontrada em ambulatórios de ginecologia em São Paulo, 16\% (NONENMACHER et al., 2002) e na Paraíba, 18,3\% (FRANCO et al., 1995) e entre as PS da Indonésia, onde a prevalência encontrada foi 37,7\% (FORD et al., 2000). Considerando-se a genotipagem, 50,7\% das pacientes positivas para o HPV, apresentaram pelo menos um genótipo de alto risco oncogênico. A prevalência de HPV de elevado grau oncogênico obtida no presente estudo é similar à obtida no Japão, pois em estudo com 546 PS que visitaram clínica de DST, a prevalência do HPV de alto e intermediário risco oncogênico foi de 48,4\%, quando se usou captura híbrida (ISHI et al., 2000). Dados semelhantes ao de Botucatu foram encontrados com grupo de PS da Bélgica, onde 77,4\% foram positivas para um ou mais tipos de HPV, sendo 55,9\% para HPV de alto risco (MAK et al., 2004).

O câncer cervical é o mais frequentemente diagnosticado entre mulheres no Sul do Vietnã, onde sua incidência é uma das maiores observadas em todo o mundo. Entre 282 PS residentes nesta área, detectaram-se DNA do HPV em $85 \%$ delas, não variando a prevalência com a idade. Trinta e cinco genótipos de HPV foram detectados, sendo o 52 o tipo mais comum. Metade das mulheres HPV-positivas foram infectadas com tipos oncogênicos e $37 \%$ estavam infectados com genótipos múltiplos (HERNANDEZ e NGUYEN, 2008). No presente estudo, a frequência de genótipos oncogênicos foi similar à descrita em mulheres HIV positivas. Em relação aos genótipos múltiplos, foi encontrada prevalência de $17,3 \%$ entre os vírus tipados, frequência inferior à relatada por Hernandez e Nguyen (2008).

Neste estudo, 5,0\% das PS tiveram alguma alteração no exame citológico, valor bastante pequeno quando comparado com estudo belga, em que alterações celulares em PS somaram 21,1\%: 2,6\% tiveram diagnóstico de células glandulares atípicas de significado indeterminado ou células escamosas atípicas de significado indeterminado, 15,6\% tiveram diagnóstico de lesão intraepitelial escamosa de baixo grau e 2,9\% tiveram lesão intraepitelial de alto 
grau (MAK et al., 2004).

A CT teve prevalência de $20,5 \%$, valor próximo ao de estudos brasileiros realizados em ambulatório de ginecologia de Goiânia/GO (ARAÚJO et al., 2002) e em clínica de DST de Manaus (SANTOS et al., 2003): 19,6\% e 20,7\% respectivamente. Houve semelhança, também, com o resultado obtido com PS do Senegal (LAURENT et al., 2003) e foi diferente do índice encontrado em Bali, Indonésia: $41,3 \%$, onde as mulheres com maior número de parceiros apresentaram maior probabilidade de serem infectadas (FORD et al., 2000). Entre as mulheres PS indianas, a prevalência foi, porém, menor, sendo encontrados 7,8\% entre as trabalhadoras em bordéis (Buzdugan et al., 2009). $\mathrm{Na}$ Guatemala, após intervenção, a prevalência diminuiu de 10,7\% para 6,2\% (SABIDÓ et al., 2009), destacando-se que esta infecção tem sido associada com idade precoce na primeira relação sexual (HARIJAONA et al., 2009).

Com relação ao TV, o valor obtido $(3,0 \%)$ foi inferior ao encontrado em ambulatório de ginecologia de Brasília, no qual a prevalência foi 4,8\% (LOBO et al., 2003) e entre PS indianas, cuja prevalência foi 5,9\% (DIVEKAR et al., 2000). Na Indonésia, a prevalência de TV foi menor que a encontrada neste estudo 2,0\%, quando se utilizou para diagnóstico o exame a fresco do conteúdo vaginal (SHETHWALA et al., 2009). A presença de TV constituiu-se em fator de risco significativo para aquisição do HIV (VAN DEN HOEK et al., 2001), estando associado à idade, baixa escolaridade e infecções genitais (HARIJAONA et al., 2009).

A prevalência de sífilis deste estudo, 4,0\%, também foi muito menor que os 29,0\% obtidos em PS de São Paulo (ARAÚJO e FORTUNA, 1990) e a de 45,0\% obtida em estudo multicêntrico de 1995 (LURIE et al., 1995). Porém, em Umuarama/PR, em estudo de 2008, o valor obtido foi ainda menor: $2,7 \%$ (Correa et al., 2008). Na China (Lu et al., 2009), Índia (SHETHWALA et al., 2009) e Guatemala (SABIDÓ et al., 2009), estudos realizados com PS encontraram prevalência de $11,0 \%, 6,6 \%$ e 8,6\% após intervenção. Tem sido apontada a associação entre ser casada e grande número de gestações com infecção por sífilis (HARIJAONA et al., 2009). 
Obteve-se 1,0\% de prevalência de HIV, valor inferior ao obtido em estudo com PS de São Paulo (ARAÚJO et al., 1990), em Vitória/ES (MIRANDA et al., 1998), em estudo multicêntrico (LURIE et al., 1995), em Umuarama/PR (CORREA et al., 2008) e na China (LU et al., 2009): 11,0\%, 9,0\% 8,6\%, 2,7\% e 2,3\%, respectivamente. Porém, na Amazônia brasileira (BENZAKEN et al., 2002) e em Mandagascar (HARIJAONA et al., 2009), nenhuma PS estudada apresentou HIV e na Indonésia a prevalência obtida foi 0,2\% (FORD Et al., 2000).

Assim como em Madagascar (HARIJAONA et al., 2009), nenhum caso de gonorreia foi identificado nesta investigação quando se utilizou a cultura em meio de Tayer Martin para diagnóstico, sendo que a prevalência desta cervicite também é bastante variada na literatura científica: 6,4\% após intervenção com PS da Guatemala (SABIDO et al., 2009), 8,3\% em mulheres assintomáticas promíscuas de Ribeirão Preto (PASSOS Et al., 1994), 9,7\% em Mumbai, Índia (DIVERKAR et al., 2000), 16,9\% entre PS de Surat City, Índia (THAKOR et al., 2004) e 60,5\% entre PS da Indonésia (FORD et al., 2000). No mesmo estudo indiano, a gonorreia foi a DST de maior frequência isolada e a DST mais associada ao HIV (DIVEKAR et al., 2000), sendo também associada, a idade e escolaridade baixas na África (HARIJAONA et al., 2009).

Também não foi identificado nenhum caso de Hepatite $B$, sendo que em PS de São Paulo a prevalência foi de 9,0\% (ARAÚJO et al., 1990), em estudo multicêntrico desenvolvido em São Paulo, Santos e Campinas foi 39,0\% (LURIE et al., 1995) e no Paraná foi 2,7\% (CORREA et al., 2008). No Japão, quando se investigou a prevalência de anticorpos para o vírus da hepatite $\mathrm{B}$ e seu antígeno de superfície, a positividade em PS foi de 0,6\% e 23,4\%, respectivamente (ISHI et al., 2001). Outro estudo realizado com PS imigrantes em Madri, Espanha, encontrou prevalência de 3,5\% para AgHBS (GUTIÉRREZ et al., 2004) e 3,3\% na Índia (SHETHWALA et al., 2009).

A hipótese inicial do estudo, de elevadas taxas de DST entre PS associadas a variáveis sociodemográficas e comportamentais não se confirmou. Os dados foram exaustivamente explorados e nenhuma associação 
foi identificada, nem quando se considerou as DST em geral, nem para o HPV, mas prevalente DST identificada.

Sintetizando o quadro de prevalência discutido, pode-se afirmar que, de uma maneira geral, a elevada taxa entre as PS de Botucatu decorre da ocorrência de HPV, mas são escassos os estudos brasileiros comparáveis. As demais DST estão, de uma maneira geral, neste município, em situação melhor ou pelo menos igual à encontrada em diversas investigações, não apenas entre PS, mas também em outros grupos populacionais, mais ou menos vulneráveis, como presidiárias, frequentadoras de clínica de DST e de ambulatório de ginecologia.

Esse quadro não pode ser considerado favorável, já que dois terços das mulheres têm alguma DST. É especialmente preocupante a situação do HPV e da CT.

O fato de a infecção pelo HPV ser conhecida como uma das DST de maior prevalência e incidência no mundo (MAGl et al., 2006) não minimiza o problema, especialmente porque a prevalência de genótipos de alto risco foi elevada $(36,3 \%)$, havendo também $31,4 \%$ de genótipos não caracterizados neste estudo, em que não se pode descartar o risco elevado. A ausência de sintomatologia e de rastreamento rotineiro torna este um problema de saúde pública, pela elevada disseminação do vírus.

Com relação à $\mathrm{CT}$, o grande impacto nas mulheres está relacionado ao fato de facilitar a infecção pelo HIV (WASSERHEIT, 1992), à possibilidade de desencadear infecção ascendente do trato genital feminino, podendo levar a endometrite, salpingite, abscessos tubo-ováricos e peritonites, em diferentes graus, algumas vezes ocasionando a morte (CDC, 2002). Com freqüência, leva ao desenvolvimento de dor pélvica crônica, infertilidade e/ou esterilidade, com inegável dano à saúde reprodutiva das mulheres (BARLOW et al., 2001). Além disso, pode causar disfunção tubária, com consequente gravidez ectópica que, na ausência de diagnóstico e tratamento imediato, acarreta a morte materna (JONES et al., 2000). Ainda merece destaque que, uma vez adquirida, essa infecção pode persistir por vários meses, propiciando um longo período de 
disseminação, agravado pela ausência de rastreamento rotineiro e curso assintomático, podendo passar despercebida mesmo ao exame clínico (MARQUES e MENEZEs, 2005), o que também contribui para que essa infecção configure problema de saúde pública.

O desenho deste estudo não permite apresentar as razões para a atual situação das DST em PS de Botucatu, nem mesmo para a falta de associação entre DST e comportamentos de risco, como uso de álcool ou drogas ilícitas. Porém, pode-se levantar a hipótese de que a política de saúde voltada a este grupo, especialmente o trabalho de promoção à saúde, desenvolvido pelos agentes estratégicos, que têm muita proximidade das PS, pode estar ajudando a adoção de alguns comportamentos preventivos, como o uso de preservativo no trabalho e a coleta sistemática de colpocitologia oncótica, minimizando certos riscos.

Mesmo assim, devido à elevada prevalência das DST, algumas ações podem ser sugeridas com vistas à promoção da saúde individual desta população: estímulo à adoção de outras práticas saudáveis, como o uso de preservativo em todas as relações sexuais e não apenas no trabalho e a vacinação contra a Hepatite $B$. Também deve ser considerada a necessidade de garantir o acesso dessa população aos serviços públicos de saúde e a adequada capacitação dos profissionais para contato com esse grupo de mulheres, buscando conhecer sua realidade.

Estudo realizado em Benim mostrou que ao longo de 6 anos (19931999) a prevalência de algumas DST diminui como: HIV $53,3 \%$ para $40,6 \%$; sífilis $8,9 \%$ para $1,5 \%$; gonorreia $43,2 \%$ para $20,5 \%$ e $9,4 \%$ para $5,1 \%$ concluindo que intervenções produzem impacto (ALARY et al., 2002). 


\section{CONCLUSÕES}


Este estudo permitiu conhecer a elevada prevalência de DST em população de PS de município de médio porte do interior paulista, sendo relevante para subsidiar o planejamento de ações de saúde voltadas a este grupo. Pode, também, subsidiar a elaboração de diagnóstico do perfil das DST em grupos de maior vulnerabilidade no Estado de São Paulo e no Brasil, onde investigações sobre essa temática são ainda pouco freqüentes e contribuir com a quebra da cadeia de transmissão dessas doenças.

Em síntese, a população estudada era majoritariamente de mulheres adultas jovens e solteiras, com escolaridade semelhante à média geral da população brasileira. Hábitos como tabagismo, uso de álcool e de drogas ilícitas, foram frequentes. A prevalência de DST nas PS foi de 71,6\%, sendo que, isoladamente, o HPV foi o agente mais frequente e, considerando-se as associações, C. trachomatis e HPV. O HIV foi detectado em 1,0\%; a sífilis foi diagnosticada em 3,9\% e TV em 3,0\% das PS incluídas no estudo. Infecções por Neisseria gonorrhoeae e hepatite B não foram diagnosticadas. Não houve qualquer associação entre DST, sinais e sintomas ginecológicos referidos e variáveis sociodemográficas e comportamentais relativas às PS. À citologia cervical convencional, a prevalência de lesões precursoras do câncer do colo uterino foi baixa: $5 \%$

Considera-se que as instituições de saúde pública devam desenvolver ações voltadas à prevenção de DST na população em geral e de PS em especial, promover a detecção precoce dos casos e o tratamento adequado para esse grupo e seus parceiros. Apesar do papel essencial, o uso do preservativo não deve ser encarado como a única forma de intervenção, pois isso resultaria em efeito apenas imediato de redução de prevalência de DST, já que para obtenção progressiva de menores taxas outras medidas são necessárias, especialmente voltadas à promoção de melhores condições socioeconômicas e culturais das PS.

Frente aos resultados obtidos, sugere-se que os serviços de saúde municipais, seja no âmbito da atenção básica ou em programas específicos, se aproximem desta população, acolhendo-a e evitando os estigmas que 
tradicionalmente a acompanham. Conhecer seus comportamentos sexuais, condições de trabalho, situação financeira, práticas associadas (como uso de álcool e drogas ilícitas), experiências de vida, características sociodemográficas, razões para desenvolverem relações sexuais desprotegidas com clientes e parceiro fixo, entre outros, têm implicações importantes para o desenvolvimento de ações de promoção à saúde voltadas à realidade vivenciada pelas PS. Sabe-se, porém, que mudar comportamento é tarefa complexa e, para ocorrer, é necessário o reconhecimento, por parte das PS, da relevância de seu papel enquanto sujeito transformador de sua realidade, na busca de melhor qualidade de vida. 


\section{REFERÊNCIAS}


ALARY, M. et al. Decline in the prevalence of HIV and sexually transmitted diseases among female sex workers in Cotonou, Benin, 1993-1999. AIDS, v.16, n.3, p. 463-470, 2002.

AMARO, S.T.A. A questão da mulher e a Aids: novos olhares e novas tecnologias de prevenção. Saúde Soc., v.14, n.2, p.88-99, 2005.

ANDREWS, W.W. et al. Midpregnancy genitourinary tract infection with Chlamydia trachomatis: association with subsequent preterm delivery in women with bacterial vaginosis and Trichomonas vaginalis. Am. J. Obstet. Gynecol., v.194, n.2, p.493-500, 2006.

AQUINO, O.S. et al. Perfil sociodemográfico e comportamento sexual de prostitutas de Fortaleza - CE. Texto Contexto Enferm., v.17, n.3, p.427434, 2008.

ARAÚJO, C.A.; FORTUNA, E.S. Seropositivity to Chlamydia trachomatis in prostitutes: relationship to other sexually transmitted diseases (STDs). Braz. J. Med. Biol. Res., v.23, n.8, p.697-700, 1990.

ARAÚJO, R.S.C.; GUIMARÃES, B.E.M. Estudo da infecção genital por Chlamydia trachomatis em adolescentes e jovens do sexo feminino no distrito sanitário leste do município de Goiânia: Prevalência e fatores de risco. Rev. Bras. Ginecol. Obstet., v.24, n.7, p.492, 2002.

BARLOW, R. et al. The prevalence of Chlamydia trachomatis in fresh tissue specimens from patients with ectopic pregnancy or tubal factor infertility as determined by PCR and in-situ hybridization. J. Med. Microbiol., v.50, n.10, p.902-908, 2001.

BAARS, J.E. et al. Vaccination uptake and awareness of a free hepatitis B vaccination program among female commercial sex workers. Women's Health, v. 19, p.61-69, 2009.

BASTOS, F.I.; CUNHA, C.B.; HACKER, M.A. Sinais e sintomas associados às doenças sexualmente transmissíveis no Brasil, 2005. Rev. Saúde Pública, v.42, supl.1, p.98-108, 2008a. 
BASTOS, F.I.; CUNHA, C.B.; BERTONI, N. Uso de substâncias psicoativas e métodos contraceptivos pela população urbana brasileira, 2005. Rev. Saúde Pública, v.42, supl.1, p.118-126, 2008b.

BASUKIE, W.I. et al. Reasons for not using condoms among female sex workers in Indonesia. AIDS Educ. Prev., v.14, n.2, p.102-116, 2002.

BELDA JÚNIOR, W. et al. Atividade in vitro de cinco drogas antimicrobianas contra Neisseria gonorrhoeae. Na. Bras. Dermatol., v.77, n.6, p.661-667, 2002.

BENZAKEN, A.S. et al. O. Baixa prevalência de DST em profissionais do sexo no município de Manacapuru - interior do estado do Amazonas, Brasil. J. Bras. Doenças Sex. Transm., v.14, n.4, p.9-12, 2002.

BENZAKEN, A.S. et al. Percepção de risco de DST e mudanças no comportamento sexual das trabalhadoras do sexo do município de Manacapuru, do interior do amazonas, Brasil. Doenças Sex. Transm., v.15, n.2, p.9-14, 2003.

BENZAKEN, A.S. et al. Intervenção de base comunitária para a prevenção das DST/Aids na região amazônica. Brasil. Rev. Saúde Pública, v.41, n.2, p.118-126, 2007.

BOILY, M.C.; ANDERSON, R.M. Human immunodeficiency virus transmission and the role of other sexually transmitted diseases. Measures of association and study design. Sex. Transm. Dis., v.23, n.4, p.312-32, 1996.

BOTELHO, S.M.N. Prostituição de Adolescentes: uma imagem construída na adversidade da sociedade. 2003. 142 f. Dissertação (Mestrado) - Escola de Enfermagem, Universidade de São Paulo, Ribeirão Preto.

BRASIL. Ministério da Saúde. SPC-CNDST/Aids. Manual de controle de DST. 3. ed. Brasília(DF); 1999.[citado 20 Nov 2007]. Disponível em: http://www.acemfc.org.br/modelo1/down/manual_controle_dst.pdf. 
BRASIL. Ministério da Saúde. Secretaria de Políticas de Saúde. Coordenação Nacional de DST e Aids. Profissionais do sexo: documento referencial para ações de prevenção das DST e da aids. Brasília: Ministério da Saúde; 2002.

BRASIL. Ministério da Saúde. Secretaria de Vigilância em Saúde. Programa Nacional de DST e Aids. Manual de bolso das doenças sexualmente transmissíveis. Brasília: Ministério da Saúde, 2006a.

BRASIL. Ministério da Saúde. Secretaria de Atenção à Saúde. Departamento de Atenção Básica. HIVIAids, hepatites e outras DST. Ministério da Saúde, $2006 b$.

BRASIL. Ministério da Saúde. Secretaria de Vigilância em Saúde. Departamento de Vigilância Epidemiológica. Hepatites Virais: o Brasil está atento. 3. ed. Brasília: Ministério da Saúde, 2008a. 60p. (Série B. Textos Básicos de Saúde).

BRASIL. Ministério da Saúde. Secretaria de Vigilância em Saúde. Programa Nacional de DST e Aids. Prevalências e freqüências relativas de doenças sexualmente transmissíveis (DST) em populações selecionadas de seis capitais brasileiras, 2005. Brasília: Ministério da Saúde, 2008b. 224p. (Série G. Estatística e Informação em Saúde).

BRASIL. Ministério do Trabalho e Emprego. Classificação Brasileira de Ocupações. Brasília: Ministério do Trabalho.. Disponível em: <http://www.mtecbo.gov.br/busca/descricao.asp?codigo=5198-05>. Acesso em: 8 mar 2009.

BREEN, C.; ROXBURGH, A.; DEGENHARDT, L. Gender differences among regular injecting drug users in Sydney, Australia, 1996-2003. Drug Alcohol Rev., v.24, n.4, p.353-358, 2005.

BRITO, A.M.; CASTILHO, E.A.; SZWARCWALD, L. AIDS e infecção pelo HIV no Brasil: uma epidemia multifacetada. Rev. Soc. Bras. Med. Trop., v.34, p.207-217, 2001. 
BUZDUGAN, R. et al. Devising a female sex work typology using data from Karnataka, India. Int. J. Epidemiol., p.1-10, 2009.

CAMEJO, M.I.; MATA, G.; DIAZ, M. Prevalencia de hepatitis B, hepatitis C y sífilis en trabajadoras sexuales de Venezuela. Rev. Saúde Pública, v.37, n.3, p.339-344, 2003.

CARRARA, S. A Aids e a história das doenças venéreas no Brasil. In: Loyola, Maria Andréa (Org). Aids e sexualidade: o ponto de vista das ciências humanas. Rio de Janeiro: Relume - Dumará/UERJ, 1994. p.73-108.

CASTLE, P. et al. Pilot study of a commercialized human papillomavirus (HPV) genotyping assay: comparison of HPV risk group to cytology and histology. J. Clin. Microbiol., v.44, n.11, p.3915-3917, 2006.

CASTRO, R.C.C. et al. Detecção de Chlamydia trachomatis em homens militares com queixas clínicas de uretrite. J. Bras. Doenças Sex. Transm., v.12, supl.1, p.4- 11, 2000.

CDC Centers for Disease Control and Prevention. Guidelines for treatment of sexually transmitted diseases. Morb. Mortal. Wkly. Rep., v.51, p.1-80, 2002.

CHÁVEZ, J.H.; CAMPANA, S.G.; HASS, P. Panorama da hepatite B no Brasil e no Estado de Santa Catarina. Rev. Panam. Salud Publica, v.14, n.2, p.9196, 2003.

CHEQUER, P. Apresentação. Rev. Saúde Pública, v.42, supl.1, p.5-6, 2007.

CHEN, X.S. et al. Sexually transmitted infections among female sex workers in Yannan, China. AIDS Patient Care STDS, v.19, p.853-860, 2005.

CHOI, S.Y.; CHEUNG, Y.W.; CHEN, K. Gender and HIV risk behavior among intravenous drug users in Sichuan Province, China. Soc. Sci. Med., v.62, p.1672-1684, 2006. 
CODES, J.S. et al. Detecção de doenças sexualmente transmissíveis em clínica de planejamento familiar da rede pública no Brasil. Rev. Bras. Ginecol. Obstet., v.24, n.2, p.101-106, 2002.

CODES, J.S. et al. Detecção de doenças sexualmente transmissíveis em ambientes clínicos na Cidade de Salvador, Bahia, Brasil. Cad. Saúde Pública, v.22, n.2, p.325-334, 2006.

COHAN, D. et al. Sex worker health: San Francisco style. Sex. Transm. Infect., v.82, n.5, p.418-422, 2006.

COOK, R.L. et al. Prevalence of Chlamydia and gonorrhoea among a population of men who have sex with men. Sex. Transm. Infect., v.78, v.3, p.190-193, 2002.

CORREA, N.A.B.; MATUMOTO, F.H.; LONARDONI, M.V.C. Doenças sexualmente transmissíveis em mulheres profissionais do sexo, Umuarama, Estado do Paraná. RBAC, v.40, n.3, p.209-213, 2008.

DAYAN, L. Pelvic inflammatory disease. Aust. Fam. Physician, v.35, n.11, p.858-862, 2006.

DE RODA HUSMAN, A.M. et al. The use of general primers GP5 and GP6 elongated at their 3 ' ends with adjacent highly conserved sequences improves human papillomavirus detection by PCR. J. Gen. Virol., v.76, n.4, p.1057-1062, 1995.

DING, Y. et al. HIV infection and sexually transmitted diseases in female commercial sex workers in China. J. Acquir. Immune Defic. Syndr., v.38, n.3, p.314-319, 2005.

DIVEKAR, A.A. et al. Disease prevalence in women attending the STD clinic in Mumbai (formerly Bombay), India. Int. J. STD AIDS, v.11, n.1, p.45-48, 2000.

EGGERT-KRUSE, W. et al. Prevalence of Chlamydia trachomatis in subfertile couples. Fertil. Steril., v.80, n.3, p.660-663, 2003. 
ENG, T.R.; BUTLER, W.T. The Hidden epidemic: confronting sexually transmitted diseases. Washington, DC: National Academy Press; 1997.

ESTÉBANEZ, P. et al. A demographic and health survey of Spanish female sex workers: HIV prevalence and associated risk factors. J. Biosoc. Sci., v.30, n.3, p.365-79, 1998.

ESTEBANEZ, P.E. et al. Women, drugs and HIVIAIDS: Results of a multicentre European study. Int. J. Epidemiol., v.29, p.734-743, 2000.

FERREIRA, W. et al. A. Susceptibilidade de cepas de Neisseria gonorrhoeae aos antibióticos utilizados para o tratamento de uretrites e cervicites gonocócicas em ambulatório de DST de Manaus-Brasil. J. Bras. Doenças Sex. Transm., v.13, n.6, p.36-40, 2001.

FIGUEIREDO, R.; AYRES, J.R.C.M. Intervenção comunitária e redução da vulnerabilidade de mulheres às DST/ Aids em São Paulo, SP. Rev. Saúde Pública, v.36, n.4, p.96-107, 2002.

FICHOROVA, R.N. Impacto of $T$. vaginalis infection on innate immune responses and reproductive outcome. J. Reprod. Immunol., v.83, p.185189, 2009.

FOLCH, C. et al. Diferencias em lãs características sociales, conductas de riesgo y prevalencia de infección por El vírus de la inmunodeficiencia humana ei nfecciones de transmisión sexual entre trabajadoras del sexo españolas e inmigrantes em Cataluña. Med. Clin. (Barc)., v.132, n.10, p.385-388, 2009.

FONCK, K. et al. Sexually transmitted infections and vaginal douching in a population of female sex workers in Nairobi, Kenya. Sex. Transm. Infect., v.77, n.4, p.271-275, 2001.

FORBI, J.C. et al. High prevalence of hepatitis B virus among female sex workers in Nigeria. Rev. Inst. Med. Trop. S. Paulo, v.50, n.4, p.219-221, 2008. 
FORD, K. et al. AIDS and STD knowledge, condom use and HIVISTD infection among female sex workers in Bali, Indonesia. AIDS Care, v.12, n.5, p.523534, 2000.

FRANÇA JÚNIOR, I.; CALAZANS, G.; ZUCCHI, E.M. Grupo de Estudos em População, Sexualidade e Aids. Mudanças no âmbito da testagem anti-HIV no Brasil entre 1998 e 2005. Rev. Saúde Pública, v.42, supl.1, p.84-97, 2008.

FRANCO E.L. et al. Transmission of cervical human papilomavírus infection by sexual activity: differences between low and high oncogenic risk types. $\mathbf{J}$. Infect. Dis., v.172, n.3, p.756-63, 1995.

FREITAS, F.; MARMONTEL, M. Violência sexual contra a mulher. In: FREITAS, F. et al. Rotinas e Ginecologia. Porto Alegre: Artmed, 2006. p.287-289.

FRIAS, M.C.A.A. et al. Freqüência de Chlamydia trachomatis, Ureaplasma urealyticum e Mycoplasma hominis na endocérvice de mulheres no menacme. J. Bras. Doenças Sex. Transm., v.13, n.3, p.5-22, 2001.

GAJEWSKA, M. et al. The occurrence of genital types of human papillomavirus in normal pregnancy and in pregnant women with pregestational insulin dependent diabetes mellitus. Neuro. Endocrinol. Lett., v.26, n.6, p.766-770, 2005.

GARCIA-CALLEJA, J.M. et al. HIV Infection in the Americas: Improving Strategic Information to Improve Responde. J. Acquir. Inmune Defic. Syndr., v.51, supl.1, p.s1-s3, 2009.

GARGIULO, F. et al. Prevalence and distribution of single and multiple HPV infections in cytologically abnormal cervical samples from Italian women. Virus Res., v.125, n.2, p.176-182, 2007.

GAYDOS, C.A. et al. Chlamydia trachomatis infections in female military recruits. N. Engl. J. Med., v.339, n.11, p.739-744, 1998. 
GILLE, G.; KLAPP, C. Chlamydia trachomatis infections in teenagers. Haurarzt, v.58, n.1, p.31-37, 2007.

GIR, E. et al. O impacto da AIDS na prática de Enfermagem: um problema de Saúde Pública. J. Bras. Doenças Sex. Transm., v.17, n.1, p.39-43, 2005.

GIRALDO, P.C. et al. Influência da freqüência de coitos vaginais e da prática de duchas higiênicas sobre o equilíbrio da microbiota vaginal. Rev. Bras. Ginecol. Obstet., v.27, n.5, p.257-262, 2005.

GOLIJOW, C.D. et al. Chlamydia trachomatis and human papillomavirus infections in cervical disease in Argentine women. Gynecol. Oncol., v.96, n.1, p.181-186, 2005.

GOSSOP, M. et al. Female prostitutes in south London: use of heroin, cocaine and alcohol, and their relationship to health risk behaviours. AIDS Care, v.7, n.3, p.253-260, 1995.

GRCE, M. et al. Detection and typing of human papillomaviruses by means of polymerase chain reaction and fragment length polymorphism in male genital lesions. Anticancer Res., v.20, n.3B, p.2097-2102, 2000.

GREGSON, S. et al. Sexual mixing patterns and sex-differentials in teenage exposure to HIV infection in rural Zimbabwe. Lancet, v.359, n.9321, p.1896903, 2002.

GUIMARÃES, K.; MERCHÁN-HAMANN, E. Comercializando fantasias: a representação social da prostituição, dilemas da profissão e a construção da cidadania. Estud. Fem., v.13, n.3, p.320, 2005.

GUO, M. et al. Distribution and viral load of eight oncogenic types of human papillomavirus (HPV) and HPV 16 integration status in cervical intraepithelial neoplasia and carcinoma. Mod. Pathol., v.20, p.256-266, 2006.

GUTIÉRREZ, M. et al. Prevalence of HIV-1 non-B subtypes, syphilis, HTLV, and hepatitis $B$ and $C$ viruses among immigrant sex workers in Madrid, Spain. J. Med. Virol., v.74, n.4, p.521-7, 2004. 
HARIJAONA, V. et al. Prevalence of and risk factors for sexually-transmitted infections in hidden female sex workers. Méd. Mal. Infect., v.39, p.909-913, 2009.

HERNANDEZ, B.; NGUYEN, T.V. Cervical human papillomavirus infection among female sex workers in southern Vietnam. Infect. Agentes Cancer, v.3, n.7, 2008.

HOBBS, C.G. et al. Human papillomavirus and head and neck cancer: a systematic review and meta-analysis. Clin. Otolaryngol.,v.31, n.4,p.259266, 2006.

INSTITUTO BRASILEIRO DE GEOGRAFIA E ESTATISTICA - IBGE. Brasília: IBGE; 2007 Disponível em: <http://www.ibge.gov.br/cidadesat/default.php> [acesso 05 jul. 2009]..

INSTITUTO BRASILEIRO DE GEOGRAFIA E ESTATISTICA- IBGE. Brasília: IBGE; 2008 Disponível em: <http://www.ibge.gov.br/cidadesat/default.php> [acesso 18 out. 2009].

ISHI, K. et al. Prevalence of human papillomavirus, Chlamydia trachomatis, and Neisseria gonorrhoeae in commercial sex workers in Japan. Infect. Dis. Obstet. Gynecol., v.8, n.5-6, p.235-239, 2000.

ISHI, K. et al. Prevalence of Human Immunodeficiency Virus, Hepatitis B and Hepatitis C Virus Antibodies and Hepatitis B Antigen Among Commercial Sex Workers in Japan. Infect. Dis. Obstet. Gynecol., v.9, n.4, p.215-219, 2001.

JANDA, W.M: Murray, P.R. et al (Eds). Manual of clinical Microbiology. 9.ed. Washington: American Society of Microbiology Press, v.1, p.520- 601.

JIMÉNEZ, A.L. et al. Prevenção de doenças sexualmente transmissíveis em mulheres: associação com variáveis sócio-econômicas e demográficas. Cad. Saúde Pública, v.17, n.1, p.55-62, 2001. 
JIMÉNEZ DÍAZ, L. et al. Prevalence of sexually transmitted diseases and the use of the condom among sex workers. Ginecol. Obstet. Mex., v.69, p.310314, 2001.

JONES, C. et al. Urine screening for gonococcal and chlamydial infections at community-based organizations in a high-morbidity area. Sex. Transm. Dis.., v.27, n.3, p.146-51, 2000;.

KONEMAN, E.W. et al. Diagnótico Microbiológico. 5. ed. Rio de Janeiro: Medsi, 2001. 1465p.

KULMALA, S.M. et al. Type-specific persistence of high-risk human papillomavirus infections in the New Independent States of the former Soviet Union Cohort Study. Cancer Epidemiol. Biomarkers Prev., v.16, n.1, p.1722, 2007.

LAU, J.T. et al. Needle sharing and sex-related risk behaviours among drug users in Shenzhen, a city in Guangdong, Southern China. AIDS Care, v.17, n.2, p.166-181, 2005.

LAU, J.T. et al. Comparing prevalence of condom use among 15,379 female sex workers injecting or not injecting drugs in China. Sex. Transm. Dis., v.34, n.11, p.908-916, 2007.

LAURENT, C. et al. Prevalence of HIV and other sexually transmitted infections, and risk behaviours in unregistered sex workers in Dakar, Senegal. AIDS, v.14, n.12, p.1811-1816, 2003.

LEE, V.; TOBIN, J.M.; FOLEY, E. Relationship of cervical ectopy to chlamydia infection in young women. J. Farm. Plann. Reprod. Health Care, v.32, p.104-106, 2006.

LINHARES, I.M. et al. Manual de Orientação FEBRASGO DSTIAIDS. São Paulo: Ponto, 2004.

LOBO, T.T. et al. A comparative evaluation of the papanicolaou test for the diagnosis of trichomoniasis. Sex. Transm. Dis., v.30, n.9, p.694-699, 2003. 
LU, F. et al. Prevalence of HIV infection and predictors for syphilis infection among female sex workers in southern China. Southeast Asian J. Trop. Med. Public Health, v.40, n.2, p.263-272, 2009.

LURIE, P. et al. Socioeconomic status and risk of HIV-1, syphilis and hepatitis B infection among sex workers in São Paulo State, Brazil. AIDS, v.9, supl.1, p.3-17. 1995;

MACIEL, G.P.; TASCA, T.; DE CARLI, G.A. Aspectos Clínicos, patogênese e diagnóstico de Trichomonas vaginalis. J. Bras. Patol. Lab., v.40, n.3, p.152$60,2004$.

MAGI, J.C. et al. Prevalência de Papilomavírus Humano (HPV) anal, genital e oral, em ambulatório geral de Coloproctologia. Rev. Bras. Coloproct., v.26, n.3, p.233-238, 2006.

MAK, R.; VAN RENTERGHEM, L.; CUVELIER, C. Cervical smears and human papillomavirus typing in sex worker. Sex. Transm. Infect., v.80, n.2, p.118120, 2004.

MANAVI, K. A review on infection with Chlamydia trachomatis. Best Pract. Res. Clin. Obstet. Gynaecol., v.20, p.941-951, 2006.

MARQUES, C.A.S.; MENEZES, M.L.B. Infecção genital por Clamydia Trachomatis e esterilidade. J. Bras. Doenças Sex. Transm., v.17, n.1, p.6670, 2005;

MAYAUD, P.; MABEY, D. Approaches to the control of sexually transmited infections in eveloping countries: old problems and modern challenges. Sex. Transm. Infect., v.80, p.174-182, 2004.

MIRANDA, S.D. et al. Úlceras genitais na mulher. Rev. Ginecol. Obstet., v.9, n.1, p.46-53, 1998.

MIRANDA, A.E.; GADELHA, A.M.J.; PASSOS, M.R.L. Impacto da infecção pela Chlamydia trachomatis na saúde reprodutiva. J. Bras. Doenças Sex. Transm., v.15, n.1, p.53- 58, 2003. 
MINISTRY OF HEALTH. PEOPLE'S REPUBLIC OF CHINA. UNAIDS, AND WHO. Update on the HIVIAIDS Epidemic and Response in China. Beijing, China: National Center for AIDS Prevention and Control, 2006.

NAUD, $P$ et al. Doenças sexualmente transmissíveis. In: FREITAS, F. et al. Rotinas e Ginecologia. Porto Alegre: Artmed, 2006. p.127-49.

NAUSSBAUM, M. Pela razão ou preconceitos: ganhar dinheiro com o uso do corpo. In: Themis. Assessoria Jurídica. Direitos sexuais. Ed.Porto Alegre: Themis, 2002. p.13-55.

NONENMACHER, B. et al. Identificação do papilomavírus humano por biologia molecular em mulheres asintomáticas. Rev. Saúde Pública, v.36, n.1, p.95100, 2002.

OKESOLA, A.O.; FAWOLE, O.I. Prevalence of human papilloma virus genital infections in sexually transmitted diseases clinic attendees in Ibadan. West Afr. J. Med., v.19, p.195-9, 2000.

OLTRAMARI, L.C.; CAMARGO, B.V. Representações sociais de profissionais de sexo sobre prevenção de doenças sexualmente transmissíveis e contracepção. Psicol Teor Prat., v.6, n.2, p.75-87, 2004.

PAAVONEN, J.; LEHNTINEN, M. Interactions between Human papillomavirus and other sexually transmitted agents in the etiology of cervical cancer. Curr. Opin. Infect. Dis., v.12, p.67-71, 1999.

PAIVA, V. et al. Sexuality of women living with HIVIAIDS in São Paulo. Cad. Saúde. Pública, v.18, p.1609-1620, 2002.

PARIS, M. et al. Prevalence of Gonococcal and Chlamydial Infections in Commercial Sex Workers in a Peruvian Amazon City. Sex. Transm. Dis., v.26, n.2, p.103-107, 1999.

PASSOS, E.P. et al. Incidência de Clamydia trachomatis e Neisseria gonorrhoea em mulheres assintomáticas promíscuas e não-promíscuas. J. Bras. Ginecol., v.104, n.1/2, p.7-9, 1994. 
PASSOS, M.R.L et al. Um clássico e potente microbicida: a ação do hipoclorito de sódio em infecções vaginais. J. Bras. Doenças Sex. Transm., v.14, n.1, p.5-15, 2002.

PASSOS, M.R.L.; VARELLA, R.Q.; MIRANDA, A.E. Chlamydia trachomatis: a epidemia silenciosa. Separata. Rio de Janeiro: Phoenix Produções Editoriais, 2003.

PASSOS, A.D.C.; FIGUEIREDO, J.F.C. Fatores de risco para doenças sexualmente transmissíveis entre prostitutas e travestis de Ribeirão Preto (SP), Brasil. Pan. Am. J. Public Health., v.16, n.2, p.95-101, 2004.

PASSOS, M.R.L. Tricomoníase: uma epidemia negligenciada. J. Bras. Doenças Sex. Transm., v.18, n.3, p.159-160, 2006.

PASSOS, A.D.C. Hepatitis B among female sex workers in Ribeirão Preto - São Paulo, Brazil. Rev. Bras. Epidemiol., v.10, n.4, p.517-524, 2007a.

PASSOS, M.R.L. et al. Accuracy of a Self-Collection Kit for the Microbiological Study of the Vaginal Content. Braz. J. Infect. Dis., v.11, n.2, p.249-253, 2007b.

PEREYRA, E.A.G.; PARELLADA, C.I. Entendendo melhor a infecção pelo Papilomavírus Humano. São Paulo: Artmed, 2003.

FOX, M. People feel invincible against STDs. American Social Health Association, n.08, 03 mai 2004.

PINTO, V.M. Abordagem Sindrômica como estratégia de controle das Doenças Sexualmente Transmissíveis. In: PAULA, I.A.; GUIBU, I.A. DST/aids e rede básica: uma integração necessária. São Paulo: Secretaria de Estado da Saúde, 2007. p.97-109.

PIRES, I.C.; MIRANDA, A.E.B. Prevalência e fatores correlatos de infecção pelo HIV e Sífilis em prostitutas atendidas em Centro de Referência DST/AIDS. RBGO, v.20, n.3, p.151-154, 1998. 
POSSAS, C.A. Apresentação. Rev. Saúde Pública, v.41, supl.2, p.3, 2007.

QUINN, T.C.; OVERBAUGH, J. HIVIAIDS in women: an expanding epidemic. Science, v.308, n.5728, p.1582-1583, 2005.

QUINN, T.C. Association of sexually transmitted diseases and infection with the human immunodeficiency virus: biological cofactors and markers of behavioural interventions. Int. J. STD AIDS, v.7, supl.2, p.17-24, 1996.

RAMOS, M.C. et al. Estudo populacional de prevalência de Clamydia trachomatis e Neisseria gonorrhoeae por PCR em urina de mulheres residentes em vila popular atendida por serviço de saúde comunitária em Porto Alegre, Brasil. J. Bras. Doenças Sex. Transm., v.15, n.2, p.20- 25, 2003.

RADONJIC, I.V. et al. Diagnosis of Trichomonas vaginalis infection: The sensitivities and specificities of microscopy, culture and PCR assay. Eur. J. Obstet. Gynecol. Reprod. Biol., v.126, p.116-120, 2006.

REED, B.D.; FORD, K.; WIRAWAN, D.N. The Bali STD/AIDS study: association between vaginal hygiene practices and STDs among sex workers. Sex. Transm. Infect., v.77, p.46-52, 2001.

REHM. J.; TAYLOR, B.; ROOM, R. Global burden of disease from alcohol, illicit drugs and tabacco. Drug Alcohol Rev., v.25, n.6, p.503-13, 2006.

RIVERO, L.R. et al.Frequency of Trichomonas vaginalis infection in couples with fertility problems. Rev. Cubana Med. Trop., v.54, n.2, p.85-90, 2002.

ROU, K. et al. A five-city trial of a behavioural intervention to reduce sexually transmitted disease/HIV risk among sex workwers in China. AIDS, v.21, n.8, p.95-101, 2007.

SABIDÓ, M. et al. The UALE Project: Decline in the Incidence of HIV and Sexually Transmitted Infections and Increase in the Use of Condoms Among Sex Workers in Guatemala. J. Acquir. Inmune Defic. Syndr., v.51, supl.1, p.s35-s41, 2009. 
SANTOS C. et al. Detection of Clamydia trachomatis in endocervical smears of sexually active women in Manaus-AM, Brasil, by PCR. Braz. J. Infect. Dis., v.7, n.2, p.91-95, 2003.

SCHACHTER, J. Biology of Chlamydia trachomatis In: Sexually Transmited Diseases. 3. ed. New York: McGraw-Hill; 1999.p.391-406.

SCHAURICH, D.; PADOIN, S.M.M. Do cuidado da mulher: questões de gênero e sua incorporação no contexto do HIVIAIDS. Esc. Anna Nery Rev. Enferm., v.8, n.1, p.101-8, 2004.

SERAFIM, D et al. Profissionais do sexo: documento referencial para ações de prevenção das DST e da Aids. 1. ed. Brasília: MS, Secretaria de Políticas de Saúde, Coordenação Nacional de DST e Aids, 2002.

SHETHWALA, N.D. et al. Sexually transmited infections and reproductive tract infections in female sex workers. Indian J. Pat. Microb., v.52, n.2, p.198199, 2009.

SHIELDS, S.A. et al. Prevalence and correlates of Chlamydia infection in Canadian Street Youth. J. Adolesc. Health, v.34, n.5, p.384-390, 2004.

SHIN, H.R. et al. Prevalence and determinants of genital infection with papillomavirus, in female and male university students in Busan, South Korea. J. Infect. Dis., v.190, p.468-76, 2004.

SILVA, N.G. et al. Fatores associados à infecção pelo HIV em trabalhadores do sexo [TS] em Santos - SP. Saúde Coletiva, v.18, n.4, p.168-172, 2007.

SILVEIRA M.F. et al. Autopercepção de vulnerabilidade às doenças sexualmente transmissíveis e Aids em mulheres. Rev. Saúde Pública, v.36, n.6, p.670-7, 2002.

SIMON, C.P.; SILVA, R.C.; PAIVA, V. Prostituição juvenil feminina e a prevenção da Aids em Ribeirão Preto, SP. Rev. Saúde Pública, v.36, n.4, p.82-87, 2002. 
SOLOMON, D. et al. Bethesda 2001 Workshop. The 2001 Bethesda System: terminology for reporting results of cervical cytology. JAMA, v.287, n.16, p.2114-9, 2002.

SOUZA, M.G. et al. Co-infecção HIV e vírus da hepatite B: prevalência e fatores de risco. Rev. Soc. Bras. Med. Tropical, v.37, n.5, p.391-395, 2004.

STRAND, A. et al. Genital human papillomavirus infection among patients attending an STD clinic. Genit. Med., v.69, p.446-9, 1993.

STRATHDEE, S.A. et al. Predictors of Sexual Risk Reduction Among Mexican Female Sex Workers Enrolled in a Behavioral Intervention Study. J. Acquir. Defic. Syndr., v.51, n.1, p.42-46.

TABORA N. et al. Chlamydia trachomatis and genital human papillomavirus infections in female university students in Honduras. Am. J. Trop. Med. Hyg., v.73, n.1, p.50-53, 2005.

TAMIM, $\mathrm{H}$. et al. Cervicovaginal coinfections with human papillomavirus and Chlamydia trachomatis. Virology, v.43, p.277-288, 2002.

TANAKA, M. Reduced Chlamydial Infection and Gonorrhea among Commercial Sex Workers in Fukuoka City, Japan. Int. J. Urol., v.5, n.5, p.471-475, 1998.

THAKOR, H.G. et al. Prevalence of Sexually Transmitted Infections in Sex Workers of Surat City. Indian J. Comm. Med., v.29, n.3, p.104-108, 2004.

TRABULSI, L.R. Microbilogia, 4.ed. São Paulo: Atheneu, 2005. 720p.

TRAN, T.N. et al. Drug use, sexual behaviours and practices among female sex workers in Hanoi, Vietnam a qualitative study. Int. J. Drug Policy, v.15, n.3, p.189-195, 2004.

TYNDALL, M.W. et al. Risky sexual behaviours among injection drugs users with high HIV prevalence: Implications for STD control. Sex. Transm. Infect., v.78, n.1, 2002. 
VAN DE HOEK, J.A.R. et al. HIV infection and STD drug addicted prostitutes in Amsterdam: potential for heterosexual HIV transmission. Genit. Med., v.65, n.3, p.146-150, 1989.

VAN DEN BRULE, A.J. et al. Rapid detection of human papillomavirus in cervical scrapes by combined general primer-mediated and type-specific polymerase chain reaction. J. Clin. Microbiol., v.28, n.12, p.2739-2743, 1990.

VAN DEN HOEK, A. et al. High prevalence of syphilis and other sexually transmitted diseases among sex workers in China: potential for fast spread of HIV. AIDS, n.15, p.753-759, 2001.

VERSTER, A. et al. Prevalence of HIV infection and risk behaviour among street prostitutes in Rome, 1997-1998. AIDS Care, v.13, n.3, p.367-372, 2001.

WALDEN, V.M.; MWANGULUBEK, K.; MAKHUMULA - NKHOMA, P. Measuring the impact of a behaviour change intervention for commercial sex workers and their potential clients in Malawi. Health Educ. Res., v.14, n.4, p.545-54, 1999.

WANG, B. et al. Vaginal Douching, Condom Use, and Sexually Transmitted Infections Among Chinese Female Sex Workers. Sex. Transm. Dis., v.32, n.11, p.696-702, 2005.

WANG, B. et al. Prevalence and predictors of HIV infection among female sex workers in Kaiyuan City, Yunnan Province, China. J. Infect. Dis., v.13, n.2, p.162-169, 2009.

WASSERHEIT, J.N. Epidemiological synergy. Interrelationships between human immunodeficity virus infection and other sexually transmitted diseases. Sex. Transm. Dis., v.19, p. 61-77, 1992.

World Health Organization. Department of HIVIAIDS. Global prevalence and incidence of selected curable sexually transmitted infections. Geneva: World 
Health Organization, 2001. [cited 2007 Nov 20]. Available from: http://www.who.int/docstore/hiv/GRSTI/003.htm.

XU, J.J. et al. HIV and STIs in clients and female sex workers in mining regions of Gejiu City, China. Sex. Transm. Dis., v.35, n.6, p.558-65, 2008.

ZHANG, J.; THOMAS, A.G.; LEYBOVICH, E. Vaginal douching and adverse health effects: a meta-analysis. Am. J. Public. Health, v.87, p.1207-1211, 1997.

YAO, Y. et al.Sexual behavior and risks for HIV infection and transmission among male injecting drug users in Yunnan, China. Int. J. Infect. Dis., v.13, n.2, p.162-169, 2009.

YUN, H. et al. Prevalence of human papillomavirus and herpes simplex virus type 2 infection in Korean commercial sex workers. J. Microbiol. Biotechnol., v.18, n.2, p.350-354, 2008. 


\section{ANEXOS}




\subsection{Anexo 1: Instrumento para coleta de dados}

\begin{tabular}{|c|c|}
\hline 1. Nome da profissional: & UNOMEPRO \\
\hline 2. Idade (anos): & UNIDADE \\
\hline 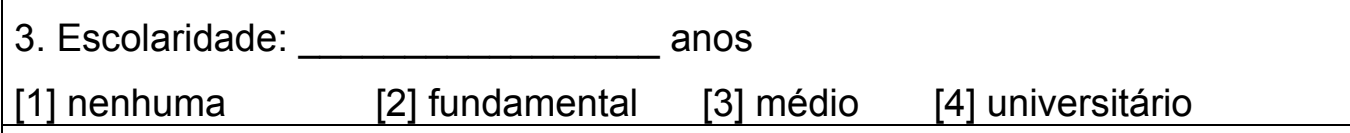 & UESCOLAR \\
\hline $\begin{array}{l}\text { 4. Número de gestações? } \\
\begin{array}{llllll}{[1] 1} & {[2] 2} & {[3] 3} & {[4] 4} & {[5] 5} & \text { [6 ] } 6 \text { ou mais [7] nenhum }\end{array}\end{array}$ & UGESTA \\
\hline 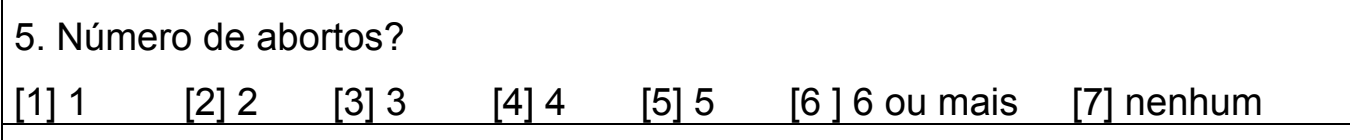 & UABORTO \\
\hline $\begin{array}{l}\text { 6. Que uso de método contraceptivo você faz? } \\
\begin{array}{lll}\text { [1] Não } & \text { [2] Horm. Oral } & \text { [3] Horm. Injetável } \\
\text { [5] Camis. Masc. [6 ] Camis. Fem. [7] Laqueadura [8 ]Outro }\end{array}\end{array}$ & $\begin{array}{l}\text { UANTICONC } \\
\text { EP }\end{array}$ \\
\hline 7. Você fuma? [1] sim. Quantos? [2] não & UFUMA \\
\hline $\begin{array}{l}\text { 8. Qual seu estado civil? [1] casada [2] solteira [3] união estável } \\
\text { [4] outro: } \\
\text { [5] divorciada/separada }\end{array}$ & UESTADO \\
\hline $\begin{array}{l}\text { 9. Você usa preservativo com parceiro fixo? } \\
\begin{array}{lll}\text { [1] sim } & \text { [2] não } & \text { [3] não tem parceiro }\end{array}\end{array}$ & UPARCEIRO \\
\hline 10. Você usa preservativo no trabalho? [1] sim & $\begin{array}{l}\text { UTRABALH } \\
\text { O }\end{array}$ \\
\hline 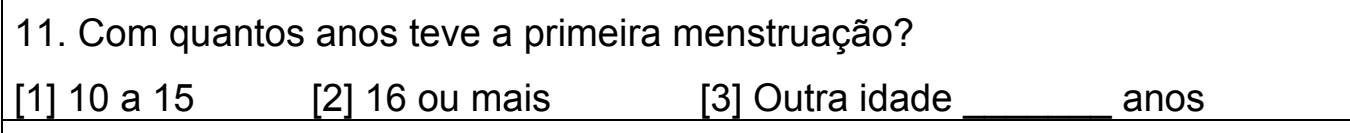 & UMENARCA \\
\hline $\begin{array}{l}\text { 12. Com quantos anos teve a primeira relação sexual? } \\
\begin{array}{llll}\text { [1] } 10 \text { a } 15 & \text { [2] } 16 \text { a } 21 & \text { [3] } 22 \text { a } 27 & \text { [4] acima de } 27\end{array}\end{array}$ & UCOITARCA \\
\hline $\begin{array}{l}\text { 13. Número de parceiros na última semana? } \\
\begin{array}{llll}\text { [1] até } 5 & \text { [2] } 6 \text { a } 11 & \text { [3] } 12 \text { a } 17 & \text { [4] mais de } 17\end{array}\end{array}$ & UPARCEI \\
\hline $\begin{array}{l}\text { 14. Número de horas da última relação sexual ? } \\
\begin{array}{llll}\text { [1] até } 24 \text { horas } & \text { [2] } 24 \text { a } 48 & \text { [3] } 48 \text { a } 72\end{array}\end{array}$ & UHORAS \\
\hline 15. Você faz sexo anal? [1] sim [2] não & UANAL \\
\hline 16. Você faz sexo oral? [1] sim & UORAL \\
\hline $\begin{array}{l}\text { 17. Você usou antibiótico no último mês? } \\
\text { [1] sim } \quad \text { [2] não } \quad \text { Qual? }\end{array}$ & UANTIBIO \\
\hline 18. Você faz uso de ducha vaginal? [1] sim & UDUCHA \\
\hline 19. Você faz uso de tampão vaginal (algodão)? [1] sim & UTAMPAO \\
\hline 20. Você já fez uso de drogas ilícitas? [1] sim & UDROGA \\
\hline
\end{tabular}




\begin{tabular}{|c|c|}
\hline $\begin{array}{l}\text { 21. Qual tipo de droga você usou ou é usuária? [1] maconha } \\
\begin{array}{llll}\text { [2] cocaína } & \text { [3] crack } & \text { [4] outras: } & \text { [5] não usou }\end{array}\end{array}$ & UTIPO \\
\hline 22. Você usa droga? [1] sim & UDROGAS \\
\hline $\begin{array}{l}\text { 23. Qual tipo de droga você usa? [1] maconha } \\
\begin{array}{llll}\text { [3] crack } & \text { [4] outras: } & \text { [5] cocaína } \\
\end{array}\end{array}$ & UTIPOS \\
\hline 24. Você faz uso de bebida alcoólica no trabalho? [1] sim & UALCOOL \\
\hline 25. Você já tomou vacina contra hepatite B? [1] sim & UHEPATITE \\
\hline 26. Você já tomou vacina contra o tétano? [1] sim & UTETANO \\
\hline $\begin{array}{l}\text { 27. Você já teve alguma doença sexualmente transmissível? } \\
\text { [1] sim }\end{array}$ & UDST \\
\hline 28. Qual? & UQUAL \\
\hline $\begin{array}{l}\text { 29. Qual o ano da última coleta de Papanicolaou? } \\
\begin{array}{lllllll}\text { [1] antes } 2000 & \text { [2] } 2000 & \text { [3] } 2001 & \text { [4] } 2002 & \text { [5]2003 [6]2004 [7]2005 }\end{array} \\
\begin{array}{lllll}\text { 8] } 2006 & {[9] 2007} & \text { [10]2008 } & \text { [5] nunca fez }\end{array}\end{array}$ & UANO \\
\hline $\begin{array}{l}\text { 30. Você tem sangramento após as relações sexuais? } \\
\begin{array}{lll}\text { [1] não } & \text { [2] sim } & \text { [3] às vezes }\end{array}\end{array}$ & USANGRAM \\
\hline 31. Você percebe corrimento vaginal? [1] sim & UCORRIM \\
\hline $\begin{array}{l}\text { 32. Há quanto tempo? [1] } \leq 7 d \quad \text { [2] 8-30d [3] }>30 d \\
\text { [4] Não percebe corrimento }\end{array}$ & UTEMPO \\
\hline $\begin{array}{l}\text { 33. Intensidade corrimento? [1] Pouco [2] Moderado [3] Intenso } \\
\text { [4] Não percebe corrimento }\end{array}$ & UINTENSI \\
\hline $\begin{array}{l}\text { 34. Que aspecto você percebe? [1] Fluido [2] Pastoso [3] Bifásico } \\
\text { [4] Bolhoso [5] Não percebe corrimento }\end{array}$ & UASPECTO \\
\hline $\begin{array}{l}\text { 35. Qual a cor? [1] Amarelo [2] Branco [3] Esverdeado [4] Acinzentado } \\
\text { [5] Não percebe corrimento }\end{array}$ & UCOR \\
\hline 36. Tem odor? [1] Não [2] Sim [3] Às Vezes [4] Não percebe corrimento & UODOR \\
\hline $\begin{array}{l}\text { 37. Tem prurido? [1] Não [2] Sim [3] Às Vezes [4] Não percebe } \\
\text { corrimento }\end{array}$ & UPRURIDO \\
\hline 38. Tem sintomas urinários? [1] Não [2] Sim Quais: & UURINA \\
\hline
\end{tabular}




\subsection{Anexo 2: Aprovação do Comitê de Ética em Pesquisa}

\section{unesp}

DIVISĀO TÉCNICA ACADÉMICA
UNIVERSIDADE ESTADUAL PAULISTA

CAMMPUS DE BOTUCATU

FACULDADE DE MEDICINA

Seçãa de Pós-Graduaçãa
Fis.

Proc.

Rub.

BOTUCATU, SP - RUBIÃO JÚNIOR - CEP 18618-970 - PABX (0xx14) 3811-6022

\section{JUSTIFICATIVA DE ALTERAÇÃO NO TÍTULO DO PROJETO DE PESQUISA}

Declaramos que o Projeto de Pesquisa "Fatores comportamentais e Prevalência das Doenças Sexualmente Transmissiveis em Mulheres Profissionais do Sexo do Município de Botucatu/SP aprovado pelo CEP em 06/10/2008, teve seu título alterado para "Prevalência das Doenças Sexualmente Tranșmissiveis em Mulheres

Profissionais do Sexo do Municipio de Botucatu/SP", sem nenhuma alteração no seu conteúdo metodológico da época de apresentação para análise do CEP.

A presente alteração foi efetuada somente para adequação do título da Dissertação de Mestrado.

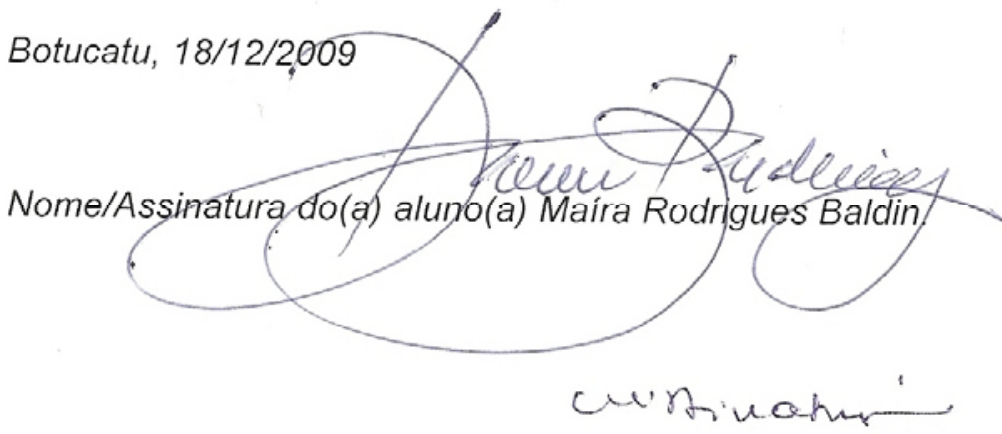

Nome/Assinatura do(a) orientador (a) Profa Dra Cristina Maria Garcia de Lima Parada

Programa de Pós Graduação em Enfermagem.

$\checkmark$ Preencher formulário em 2 vias e protocolar no respectivo CEP 


\subsection{Anexo 3: Termo de Consentimento Livre Esclarecido}

\section{TERMO DE CONSENTIMENTO LIVRE E ESCLARECIDO}

Convidamos a senhora para participar da pesquisa "Fatores comportamentais e prevalência das Doenças Sexualmente Transmissíveis em mulheres profissionais do sexo do Município de Botucatu, São Paulo" que tem por objetivo avaliar os fatores comportamentais bem como conhecer o número de casos de Doenças Sexualmente Transmissíveis em mulheres profissionais do sexo. Sua participação implicará em responder ao questionário com dados sócio-demográficos, como: escolaridade, número de gestações, partos e abortos e estado civil e de comportamento, incluindo tabagismo, uso de álcool e drogas, uso de preservativo e outros métodos anticoncepcionais, número de parceiros e práticas sexuais e uso de ducha ou tampão vaginal, o que será feito de forma não identificada, e submeter-se a coleta de sangue e exame ginecológico, que será realizado pela pesquisadora. Para o exame ginecológico, será necessária a introdução de um aparelho descartável, estéril, conhecido como "bico de pato" (espéculo), que afastará as paredes vaginais, a fim de permitir a visualização das mesmas e do colo do útero, bem como a coleta de amostras (conteúdo vaginal e secreção cervical) para exames laboratoriais. O material da parede vaginal e do colo do útero serão coletados por meio de um cotonete (swab), para verificação da presença de microorganismos que causam doenças. Será, também, realizada coleta de material com uma espátula de madeira (tipo palito de sorvete) e escovinha para fazer o exame de Papanicolaou. Esta pesquisa é de responsabilidade da Enfermeira Maíra Rodrigues Baldin, sob orientação da Prof ${ }^{a}$ Adjunta Cristina Maria Garcia de Lima Parada, do Departamento de Enfermagem da Faculdade de Medicina de Botucatu.

Pelo presente instrumento, eu devidamente esclarecida, ciente da autorização a mim solicitada, não restando quaisquer dúvidas a respeito do lido e explicado, e ciente, também, de que as informações serão utilizadas exclusivamente pelas pesquisadoras, que manterão sigilo sobre minha identidade, e que as mesmas estarão disponíveis para responder a quaisquer perguntas e de que posso retirar este consentimento a qualquer hora sem prejuízo do meu atendimento neste serviço, firmo meu CONSENTIMENTO LIVRE E ESCLARECIDO, concordando em participar da pesquisa proposta. Este documento após aprovação do CEP será elaborado em 2 vias, sendo 1 entregue ao sujeito da pesquisa e outro será mantido em arquivo pelo pesquisador.

Botucatu, de de 200_

\section{Assinatura da paciente}

Enfa Maíra Rodrigues Baldin

Unidade da Saúde da Família Jardim Iolanda

R: Lourenço Castanho, 2114- Jd. Iolanda - CEP 18609-70/Botucatu - S.P- Brasil (0143882-9731).

Prof $^{a}$. Dra. Cristina Maria Garcia de Lima Parada

Faculdade de Medicina de Botucatu - Departamento de Enfermagem

Rubião Júnior, s.n- CEP 18618-970 - Botucatu - S.P- Brasil (0143811-6070). 